\title{
Disclosure, Firm Growth, and the JOBS Act*
}

\author{
Anantha Divakaruni ${ }^{\ddagger}$ and Howard Jones ${ }^{\dagger}$
}

May 16, 2021

\begin{abstract}
We study the effects of regulatory disclosure on investment and growth by comparing newly public firms before and after they lose disclosure exemptions under the Jumpstart Our Business Startups (JOBS) Act. Exempt firms invest more in physical assets, innovation, and acquisitions than firms that lose exemptions, but experience steeper declines in growth opportunities over time. Firms that lose exemptions exhibit better allocation of equity to investments and utilization of existing assets, which improves their Tobin's $q$. Relaxing disclosure requirements seems to induce inefficiencies in managerial investment decisions and hence inhibits firms from exploiting or replenishing their growth opportunities.
\end{abstract}

Keywords: Information Disclosure, Initial Public Offerings, Regulation, Firm Financing, JOBS Act

JEL classifications: G14, G24, G28, G32

\footnotetext{
* We are grateful to Renée Adams, Philip Bond, Stefano Cassella, Dragana Cvijanovic, Thomas Hellmann, Hans Hvide, Bige Kahraman, Camelia Kuhnen, Alan Morrison, Thomas Noe, Ken Okamura, Ilaria Piatti, Ludovic Phalippou, David Robinson, Jason Zein, and, Haoxiang Zhu, as well as seminar participants at University of Oxford, University of Bergen, Warwick Business School, and University of Exeter. All errors are our own.

* University of Bergen; Email: anantha.divakaruni@uib.no

${ }^{\dagger}$ Saïd Business School, University of Oxford; Email: howard.jones@sbs.ox.ac.uk
} 


\section{Introduction}

Does lowering disclosure requirements for public firms increase information asymmetries, meaning reduced accountability and shareholder value, or does it allow managers to focus on company-building and growth? Proponents of lower disclosure argue that the administrative burden of reporting diverts managers from capital investment and innovation, and discourages them from raising public equity (IPO Task Force, 2011). Recent studies support these claims by showing that public firms innovate less after their initial public offering (IPO) (Bernstein, 2015), invest less than private firms (Asker, Farre-Mensa and Ljungqvist, 2015), and are less risk-taking under stricter disclosure (Kang, Liu and Qi, 2010).

In this paper, we study the effects of regulatory disclosure requirements on the financing, investment, and growth opportunities of a subset of public firms that were previously exempt from such obligations under the Jumpstart Our Business Startups (JOBS) Act. Our main finding is that exempt firms invest more in physical assets, innovation, and acquisitions, but experience steeper declines in Tobin's $q$ over time. We also find a positive relation between equity raising and investment, and a shift towards more efficient utilization of existing assets, once these firms lose their exemptions, which leads to a strong improvement in their Tobin's $q$. Our findings highlight a previously unrecognized outcome of the JOBS Act, and suggest that, by giving firms the flexibility to select their optimal level of disclosure, the Act is leading them to grow their assets but not to add value. ${ }^{1}$

Previous work suggests that financing investment in future growth is an important motive for firms to go public (Brau and Fawcett, 2006; Ritter and Welch, 2002). Newly public firms fund investments mainly through public equity issues (Choe, Masulis and Nanda, 1993; Lowry, 2003), and facilitate growth by building new capacity through capital expenditure (capex) and innovation (Asker, Farre-Mensa and Ljungqvist, 2015; Brown, Fazzari and Petersen, 2009), as well as by acquiring the assets of other firms (Aslan and Kumar, 2011; Brau, Francis and Kohers, 2003). It is plausible that relaxing the disclosure burden facilitates such investments without inducing short-termist pressures on managers. On the other hand, reduced disclosure limits investors' ability to monitor managers and provides incomplete information about

\footnotetext{
${ }^{1}$ As is common in the finance and accounting literature, we use the terms "firm value" and "growth opportunities" interchangeably throughout the paper.
} 
managerial risk-taking and the long-term value of their investment decisions.

The JOBS Act was passed on April 5, 2012 to ease the regulatory disclosure burden on firms going public by creating a new issuer category named "Emerging Growth Company" (EGC). ${ }^{2}$ EGCs are newly public firms that benefit from certain deburdening provisions post-IPO, including reduced disclosure requirements while raising public equity, as well as waivers on auditor attestation and disclosure of executive pay. Under Title I of the Act, these exemptions can last for up to five years as long as the EGC's float is below $\$ 700$ million. $^{3}$

We investigate the effect of financing and investment decisions on the growth opportunities of EGCs before and after they lose disclosure exemptions under the JOBS Act (and become ExEGCs). However, identifying how a firm's EGC status affects future growth is empirically challenging. This is mainly because the JOBS Act bundles Title I along with other provisions to facilitate fundraising, especially in private markets. ${ }^{4}$ Identifying a control group of public firms unaffected by the Act is also difficult as the vast majority of post-JOBS IPO issuers have opted for EGC status, and there have been changes in the type of firm going public after the Act's passage (Dambra, Field and Gustafson, 2015).

To address these challenges, we use a regression discontinuity $(\mathrm{RD})$ design for our analysis. Specifically, we exploit the fact that an EGC will cease to remain exempt any time during the first five years if its float exceeds $\$ 700$ million on the last day of the most recent second fiscal quarter. EGCs that remain below this threshold continue to be exempt whereas those that cross it become "Large Accelerated Filers" (LAFs) subject to full disclosure under securities laws. Our RD framework compares EGCs below the \$700 million cutoff with ExEGCs above that are no longer exempt. ${ }^{5}$ This design provides a quasi-natural experiment in which the disclosure

\footnotetext{
2 Title I was drafted based on proposals of the initial public offering (IPO) Task Force, which had identified uncertainty in the IPO process, high reporting costs, and managerial focus on compliance rather than innovation and firm building as hampering the revival of US public markets (IPO Task Force, 2011). Prior legal scholarship has also called for significant modification or repeal of mandatory disclosure required under US securities laws (Greenstone, Oyer and Vissing-Jorgensen, 2006; Mahoney, 1997; Palmiter, 1999; Romano, 1998).

${ }^{3}$ Market value of common equity held by non-controlling, public investors. Other conditions needed to maintain EGC status for the full five-year period are discussed in Section 1.

${ }^{4}$ See Appendix $C$ for a detailed overview of these provisions.

${ }^{5}$ The empirical methodology used in this paper is similar to the quasi-difference-in-differences framework used by Chaplinsky, Hanley and Moon (2017) to study changes in costs of going public in response to the JOBS Act, and by Dambra and Gustafson (2021) to study how the JOBS Act's provisions affect investment and innovation during the first two years after IPO. Both studies compare firms under \$75 million float at IPO (that had been benefiting from disclosure and compliance exemptions as a "Smaller Reporting Company" since 2008) to IPO
} 
requirements intensify for a subset of public firms that were previously exempt from them. With this design, we avoid confounding the effect of the LAF rule on EGCs with unobserved shocks to all publicly traded firms. ${ }^{6}$

We recognize that EGCs may actively manipulate their float to stay below the cutoff and avoid compliance with the LAF rule. To correct for this, we use the float six months before the $L A F$ day (last day of second fiscal quarter) as an instrument to predict loss of EGC status. The float six months prior does not itself determine whether an EGC will remain exempt for the next fiscal year, and thus has no direct bearing on whether it retains or loses its status on the LAF day. However, the instrument strongly predicts the float on the LAF day, which solely determines the firm's future status as an EGC. We conduct several tests to establish the validity of our instrument and find that float manipulation occurs mostly during the six months preceding the LAF day and when the float is closer to the cutoff, but much less so otherwise. In other words, EGCs are unlikely to actively avoid having a float above $\$ 700$ million unless the threat of losing disclosure exemptions is imminent.

We first investigate equity and debt issuance by EGCs before and after they lose exemptions. EGCs that lose exemptions and become ExEGCs tilt their capital raising towards debt rather than equity. For the median EGC with $\$ 116$ million in assets, this amounts to a $\$ 39$ million increase in debt issuance following loss of exemptions. The fact that equity raising is less preferred under stricter disclosure is consistent with EGCs preferring the Act's disclosure exemptions despite the associated loss of transparency for investors and higher cost of capital. ${ }^{7}$

We next explore the real effects of disclosure by investigating how it affects investments by EGCs when they lose exemptions. Capex falls by 19\% (representing \$16 million less yearly spending on physical assets by the median EGC) while annual R\&D expenditure drops by $14 \%$ (equivalent to $\$ 12$ million for the median EGC). There is also a $18 \%$ decline in acquisitions and a $15 \%$ drop in the use of cash as acquisition currency once an EGC becomes an ExEGC.

firms with float above this threshold that would have qualified for similar exemptions only under the JOBS Act. ${ }^{6}$ A drawback of the RD method, as noted by Leuz and Wysocki (2016) (p.564), is that our results do not generalize to EGCs with a float much larger (or smaller) than the cutoff, or to firms subject to mandatory disclosure for other reasons. However, analysing the LAF rule is important since it is the main reason why the median duration that an EGC remains exempt is only two years, and calls to question whether the JOBS Act has been able to stimulate capital raising and firm growth.

${ }^{7}$ See Barth, Landsman and Taylor (2017) and Chaplinsky, Hanley and Moon (2017) for related evidence that EGCs value the JOBS Act's provisions highly despite greater investor uncertainty and higher IPO issuance costs. 
These results suggest that stricter disclosure requirements constrain ExEGCs from pursuing new investments. While evidence that reduced disclosure increases investment in innovation and acquisitions has featured in recent literature (Balogh, Creedy and Wright, 2021; Dambra and Gustafson, 2021), we show that these effects are reversed once mandatory disclosure becomes applicable. Moreover, the increase in investments under reduced disclosure is rather short-lived since the average EGC loses its exemptions within two years of going public.

Prior studies note that investment falls under stricter disclosure because it diverts managerial attention from pursuing new investment opportunities (Bernstein, 2015; Coates and Srinivasan, 2014; Dambra and Gustafson, 2021). However, if disclosure improves external monitoring (Leuz and Wysocki, 2016), it should also improve the efficiency with which EGCs allocate capital to investments. Consistent with these hypotheses, we find equity raising by EGCs to be associated with fewer investments in capex, innovation and employees. Among ExEGCs, by contrast, these relationships are positive and significant. This evidence suggests that freedom from disclosure encourages inefficient equity allocation that is also difficult for stock market investors to monitor. On the other hand, debt does not feature strongly in the investments by EGCs. This finding is consistent with young firms funding their internal activities, especially innovation, mainly using equity (Brown, Fazzari and Petersen, 2009).

As for external investments in the form of acquisitions, we find no association between equity or debt raised by EGCs and their acquisition activity. However, ExEGCs seem to time their equity issuance, at least partly, to fund acquisitions. This finding once again points to stricter disclosure creating strong managerial incentives to improve investment efficiency.

If stricter disclosure allows better monitoring and focuses managerial attention on investing efficiently, it follows that a switch to ExEGC status should also provide substantial valuation benefits. To test this hypothesis, we use the Tobin's $q$ ratio as an ex-ante measure of firm value and growth. Tobin's $q$ reflects the value placed by the market on the firm's assets relative to their book value, and incorporates long-term growth created from investment in physical and intangible assets as well as acquisitions (Ho, Tjahjapranata and Yap, 2006; Lang, Lins and Maffett, 2012). ${ }^{8}$ We find that Tobin's $q$ declines more rapidly over time for EGCs than for

\footnotetext{
${ }^{8}$ Tobin's $q$ is an appropriate proxy of growth opportunities for our setting since newly public firms invest mainly in innovation (Bernstein, 2015; Dambra and Gustafson, 2021), which is an intangible investment that contributes
} 
ExEGCs. Moreover, the fraction of ExEGCs with a Tobin's $q$ exceeding their Tobin's $q$ at IPO is consistently higher than that of EGCs. These findings indicate that even though EGCs invest more in physical assets, innovation and acquisitions, they are less capable of generating incremental growth opportunities than their fully disclosing peers. This causes real economic losses as exhibited by the lower market valuation of EGC firms.

To better understand the channels through which changes in disclosure affect firm growth, we study how fundraising and investment decisions by firms conditional on their EGC status affect their Tobin's $q$ in the following year. We find both equity and debt raised by EGCs to be associated with a lower Tobin's $q$. Conversely, a one standard deviation increase in equity (debt) issuance by an ExEGC leads to an increase of $1.81(0.85)$ in its Tobin's $q$. The sensitivity of Tobin's $q$ to EGC status and equity raising is expected because Title I restricts the level of information revealed to the stock market during equity issuance. We also find that EGC investments in capex, PPE, and R\&D exert a negative effect on Tobin's $q$. This relation reverses among ExEGCs - except in the case of R\&D, likely because future benefits accruing from innovation are harder to value than similar investment in physical assets. By contrast, there is a positive association between acquisitions by an EGC and its future Tobin's $q$, which is reversed for ExEGCs. A possible explanation for this result is that managers are incentivized to overstate the goodwill portion of the purchase price of an acquisition, and project better growth prospects from such deals, when disclosure requirements are low. Overall, we conclude that fundraising is less efficient, and that investments made under reduced disclosure contribute lesser value to the firm than under full disclosure.

Lastly, in line with the above results, we find that EGCs become more profitable, earn better returns on investment, and are less financially constrained upon transitioning to full disclosure. This evidence suggests that stricter disclosure causes EGC managers to shift focus from pursuing new investments towards improving profitability through the efficient utilization of existing assets. It also implies that stricter disclosure has a disciplining effect on firms, leading

\footnotetext{
to the long-term growth of the firm. Tobin's $q$ also represents the firm's ability to generate cash flow from its assets over the long term, including those that accrue with significant delay. Relatedly, Ho, Tjahjapranata and Yap (2006) argue that using an ex-post measure of firm value or performance obscures the real effects of innovation since they could be affected by the firm's endogenous characteristics and market conditions during the intervening period. Lang, Lins and Maffett (2012) note that Tobin's $q$ also inherently incorporates the cost of capital used to discount future cash flows.
} 
them to shift from engaging in capacity building and innovation towards lowering costs and improving the earnings potential of existing products and services.

Although our RD framework is well-suited to identify how mandatory disclosure affects the investment and future growth of EGCs, it makes no explicit consideration of the underlying causal mechanisms. However, we believe that our RD design imposes significant restrictions on any nondisclosure-related interpretation of our results. Although media reports suggest that the JOBS Act has simplified the IPO process and freed up managers from compliance (Teach, 2014), we find that the resulting loss of information to investors contributes to a lower growth trajectory for EGC firms.

Our paper makes several contributions to literature. First, our findings highlight that the real benefits of mandatory disclosure, as measured by growth opportunities, outweigh the managerial freedom and cost savings resulting from deburdening regulations like the JOBS Act. This contributes new evidence to the literature that has focused on how disclosure affects corporate investment (Coates and Srinivasan, 2014; Dambra and Gustafson, 2021; Gao and Zhang, 2018; Kraft, Vashishtha and Venkatachalam, 2018), but has largely been silent on how disclosure-contingent financing and investment affect firm growth. Second, our paper adds to the literature on the determinants of firm value (Bushee and Leuz, 2005; Greenstone, Oyer and Vissing-Jorgensen, 2006; Loderer, Stulz and Waelchli, 2017), and shows that Tobin's $q$ falls more rapidly over time among disclosure-exempt firms. Third, our paper contributes to the vast literature on why firms invest and innovate. Recent work in this field shows that the JOBS Act has led to more investment in innovation (Dambra and Gustafson, 2021) and acquisitions (Balogh, Creedy and Wright, 2021) among newly public firms (i.e., EGCs). We add to this literature by studying whether EGC managers carry out these activities efficiently, and show that investing under reduced disclosure does not lead them to exploit growth opportunities or make investments that are considered value-adding by investors. ${ }^{9}$

Our paper proceeds as follows. Section 1 provides an overview of the institutional setting

\footnotetext{
${ }^{9}$ We provide additional evidence in online appendices D and E that EGCs experience an increase in compliance costs after they lose their exemptions. Specifically, we show that EGCs face an increase in audit fees and have weaker control over earnings and revenue recognition upon loss of exemptions. The rise in compliance costs under stricter disclosure explains, at least in part, why many EGCs attempt to prolong their exemptions by manipulating their float to stay below the $\$ 700$ million threshold.
} 
and related literature. Section 2 describes the empirical framework. Section 3 describes the data. Section 4 presents the empirical analysis and results. Finally, Section 5 concludes.

\section{Institutional setting and related literature}

The JOBS Act represents one of the most significant deregulation of US securities laws in the past four decades. It was enacted to stem the decline in the number of IPOs and of companies listed on US stock exchanges (Doidge, Karolyi and Stulz, 2017; Gao, Ritter and Zhu, 2013), and improve access to capital particularly for emerging, high-growth companies.

The main feature of the JOBS Act called "Title I" (formally "Reopening American Capital Markets to Emerging Growth Companies") went into effect on April 5, 2012. ${ }^{10}$ Title I contains several on-ramp exemptions that permit firms with revenue below $\$ 1$ billion in the most recent fiscal year to skip certain registration requirements and go public as an Emerging Growth Company (EGC). ${ }^{11}$ Title I also contains several de-burdening provisions that reduce mandatory financial and executive disclosure during IPO filing and in subsequent reporting. Principal among these is scaled disclosure under which an EGC may omit disclosing items related to executive compensation and management performance. ${ }^{12}$ Title I further exempts EGCs from Section 404(b) of the Sarbanes-Oxley Act (SOX) that mandates external auditor attestation of the quality and reliability of the firm's financial reporting. The primary goal of these provisions is to encourage newly public firms to raise capital that can be used to "grow their businesses, pursue promising new products and innovations, and create jobs” (IPO Task Force, 2011).

Not surprisingly, the JOBS Act not only generated much interest in the media, but has also been the subject of several academic studies in the fields of finance, law, and accounting. An

\footnotetext{
${ }^{10}$ See Table $\mathrm{C} 1$ in the appendix for a detailed timeline of the JOBS Act.

${ }^{11}$ These on-ramp provisions include: (i) Confidential filing of draft registration statements (via Form S-1), allowing would-be issuers to get feedback from the SEC before the filings are made public, and (ii) Testing-thewaters (TTW), permitting issuers to engage with prospective investors and gauge their interest in the offer. ${ }^{11}$ TTW overrides the previous ban on communication with investors prior to a public offer. These provisions allow an EGC to withdraw its offer and avoid disclosing confidential information, or proceed by making its filings public at least 21 days before commencing the roadshow.

${ }^{12}$ Specifically, under scaled disclosure provisions, EGCs must include only two, rather than three, years of audited financial statements in its offer filings. EGCs must provide basic compensation details of only three, rather than five, executive officers, and are exempt from Say-on-Pay and Say-on-Golden Parachute voting requirements under Section 951 of the Dodd-Frank Act. EGCs can also opt not to discuss the relationship between management performance and executive compensation, nor to reveal the CEO's salary relative to median employee wage.
} 
early study by Dambra, Field and Gustafson (2015) finds the on-ramp provisions as particularly popular among firms going public, resulting in a $25 \%$ rise in IPO volume over pre-JOBS levels. However, their study does not explore whether IPO firms opting to become an EGC were indeed the kind targeted by policymakers: emerging, high-growth companies. We address this question in the current paper.

Barth, Landsman and Taylor (2017) and Chaplinsky, Hanley and Moon (2017) study the quality of information disclosure by EGCs. They find that EGC firms eliminate some of the previously mandated disclosures, thereby causing greater information uncertainty in the IPO market and an escalation in the costs of going public. Dambra and Gustafson (2021) investigate how the de-burdening provisions of the JOBS Act affect the investment and innovation of newly public EGCs. The empirical setting in both Chaplinsky, Hanley and Moon (2017) and Dambra and Gustafson (2021) is the subset of firms whose float is just above or below \$75 million. Firms above this threshold (Non-Smaller Reporting Companies, NonSRCs) are eligible for the JOBS Act's de-burdening provisions while firms below the threshold (Smaller Reporting Companies, SRCs) have had access to similar exemptions since February $2008 .{ }^{13}$ Using this framework, Dambra and Gustafson (2021) find that NonSRCs going public after the Act invest more during the first year following their IPO, relative to NonSRCs that went public earlier as well as SRCs both before and after the Act. They also find that this rise in investment among NonSRC EGCs is concentrated in R\&D, but not capex.

Dambra and Gustafson (2021) focus only on the firm's first eight quarters as a public company, and do not cover funds raised or changes in disclosure requirements post-IPO. This is a major limitation because EGCs are exempt under the JOBS Act for a maximum of five years after the IPO, and are allowed to use the Act's provisions when raising more capital in public markets. ${ }^{14}$ In the current paper we consider all EGCs with float between $\$ 350$ million and $\$ 1,050$ million (i.e., firms larger than SRCs that went public only by utilizing the JOBS Act's provisions).

An EGC can lose its exemptions any time during the five years after IPO if it meets any of

\footnotetext{
${ }^{13}$ Although SRCs do not qualify for de-burdening provisions under the JOBS Act, they however do qualify for on-ramp exemptions similar to EGCs.

${ }^{14}$ In fact, we show in Appendix B that EGC firms raise considerable equity in public markets following their IPO.
} 
the following conditions: (i) annual gross revenue exceeds $\$ 1$ billion ( $\$ 1.07$ billion since 2017), (ii) total non-convertible debt issued during the past three years exceeds $\$ 1$ billion, and (iii) the float is $\$ 700$ million or more as of the last business day of the most recently completed second fiscal quarter. If an EGC breaches the $\$ 700$ million float threshold it loses its exemptions under the JOBS Act's provisions and becomes a "Large Accelerated Filer" (LAF) subject to mandatory disclosure requirements.

We focus on the LAF regulation, which is a potential constraint for many EGCs, while the other two conditions that would deprive them of their EGC status are rarely met by newly public companies. The disclosure requirements of the LAF regulation are an incentive for some EGCs to remain as such, and raises the question whether they are able to remain exempt for the maximum possible period. Firms with investment needs may want to return to the public markets before they cease to be an EGC if they find the lower disclosure costs and freedom from reporting obligations under the JOBS Act appealing. In fact, they could even attempt to delay enforcement of the LAF rule and prolong their time as an EGC by manipulating their float or by substituting public equity with debt financing. ${ }^{15}$

The main contribution of this paper is to isolate the regulatory effects of losing EGC status and becoming a fully disclosing company (as an LAF) from other contemporaneous changes in securities regulation and market conditions. We focus on the effect of the LAF regulation on fundraising, internal and external investments, and firm value. Together these are an important area of study because the JOBS Act was intended for emerging, high-growth companies that are expected to have substantial funding needs.

Dambra, Field and Gustafson (2015) note that the on-ramp provisions of the JOBS Act prevail over its de-burdening provisions during IPO, and likely cause a different type of firm to go public. A question remains whether these provisions affect firms' fundraising decisions and investments post-IPO, especially given the threat of transition to full disclosure under the LAF rule. Relatedly, Alsabah and Moon (2020) estimate the float deficit for newly public firms after the JOBS Act by comparing the actual float to a predicted value based on pre-JOBS

\footnotetext{
${ }^{15}$ Note that once an EGC becomes an LAF, it can subsequently transition to "accelerated filer" or "non-accelerated filer" status should its float fall below $\$ 560$ million. However, such transitions do not reduce the disclosure burden substantially (at least up to the extent that disclosure exemptions benefit EGCs). We therefore regard a change to LAF status as permanent in our analysis.
} 
sample estimations. They find that firms having a float deficit with respect to the $\$ 700$ million LAF threshold are likely to raise more debt. However, their analysis considers book leverage only, does not account for changes in the type of firm going public after the Act, and does not consider equity issuance post-IPO that would directly affect the float. Our study differs by quantifying the direct effects of the LAF rule on EGCs, and how this rule impacts the financing, investment and growth trajectory of these firms. For this we use clean treatment and control groups around the LAF threshold, as discussed in the next section.

\section{Identification}

Our aim is to investigate the effects of mandatory disclosure on fundraising, investment policies, and the growth opportunities of EGC firms. A naïve approach t would be to compare the outcomes for EGCs and LAFs which went public before the JOBS Act in a cross-sectional setting. However, this method would not capture causal effects of the LAF rule on EGC firms, as only those with float above $\$ 700$ million will become subject to mandatory disclosure. Moreover, EGCs may have different characteristics compared to LAFs that went public before the Act and thus did not have the benefit of disclosure exemptions at that time.

We employ two unique strategies to overcome this problem. First, we take EGCs that went public on or before December 31, 2017 and construct a rolling window sample for each firm in this set, starting from the first day of the third fiscal quarter of year $t$ (after the IPO) to the last day of the second fiscal quarter of year $t+1$ (spanning four quarters per window). ${ }^{16} \mathrm{An}$ EGC enters the sample if its float is below $\$ 700$ million at the start of the first window after its IPO. At each window end, the firm remains an EGC if it has a float below $\$ 700$ million and does not get delisted during this period. Alternatively, the firm is classified as an ExEGC if its float exceeds $\$ 700$ million by the window end. An EGC that loses its exemptions to the LAF rule cannot be reclassified as an EGC. This sample construction method enables us to isolate the effects of LAF regulation on EGC firms from other unrelated factors.

Second, we use a regression discontinuity (RD) design for estimation. This design is similar to the method used by Iliev (2010) to study the impact of Section 404 of the Sarbanes-Oxley

\footnotetext{
${ }^{16}$ Fiscal years are different from calendar years. A fiscal year covers twelve consecutive months spanning four quarters, with a start date that differs across firms. For example, some firms begin their fiscal year on $1^{\text {st }}$ January and end on $31^{\text {st }}$ December, while others have a fiscal year from $1^{\text {st }}$ April to $31^{\text {st }}$ March of the following year.
} 
Act (SOX) on public firms. Our RD method compares the outcomes of interest for EGCs that find themselves either above or below the $\$ 700$ million cutoff at each window end (second fiscal quarter of year $t+1)$. EGCs below the cutoff remain exempt from disclosure whereas EGCs above the cutoff will cease to be exempt and become an LAF (i.e., an ExEGC). As a result, an ExEGC is required to submit quarterly and annual reports, management report of internal controls, and independent audit reports at the end of each fiscal year to the SEC.

Our RD design focuses on EGCs around the $\$ 700$ million cutoff as it reduces bias from unobservable characteristics that might be confounded with float and the outcomes of interest. Accordingly, the estimated difference in outcomes between EGC and ExEGC firms can be ascribed directly to the loss of EGC exemptions. Our baseline specification is:

$$
Y_{t}=\beta_{1} \cdot E x E G C_{t}+\beta_{2} \cdot X_{t}+\gamma \cdot f\left(P F_{t}\right)+\delta_{j}+\lambda_{t}+\varepsilon
$$

where ExEGC is a dummy equal to one if the float of an EGC exceeds $\$ 700$ million on the last day of second fiscal quarter in year $t$, and zero otherwise. $X_{t}$ is a vector of observable EGC characteristics. Coefficient $\beta_{1}$ identifies the causal effect of EGC status loss on the outcome of interest $Y_{t}$ at year end. An unbiased estimation of $\beta_{1}$ requires strong assumptions about the unknown relationship between $Y_{t}$ and the float, $P F_{t}$. These assumptions are required because estimating treatment effects near the cutoff might also require use of data further away from the cutoff (Lee and Lemieux, 2010). We thus adopt two complementary strategies to estimate equation (1) when the functional dependence of $Y_{t}$ on $P F_{t}$ is unknown. First, we restrict the sample to a specific bandwidth $h$ on either side of the treatment to minimize biases in the RD estimation. Focusing on EGCs within this narrow bandwidth minimizes bias from unobservable factors that might be confounded with $P F_{t}$. Second, we include up to the third order polynomial in $f\left(P F_{t}\right)$ to eliminate any non-linear effects of $P F_{t}$ on $Y_{t}$.

One major assumption of this sharp RD design is that EGCs do not anticipate status loss due to the LAF regulation and have no influence over their float. If this assumption holds, then OLS regressions based on equation (1) will provide true, unbiased estimates of the impact of EGC status loss on $Y_{t}$. Contrarily, OLS estimates will be biased if some EGCs manipulate their float to evade becoming an LAF. We assess this in Figure 1 using the Cattaneo, Jansson and Ma (2019) test for discontinuities of the float density at the cutoff. The left-hand plot in Figure 
1(a) presents the density of float at the end of each second fiscal quarter for EGCs. The density estimate at the cutoff has a $t$-statistic of $-2.756(p$-value $=0.006)$. This suggests that some EGCs avoid losing their exemptions by manipulating their float. Firms can reduce their float by increasing the shares held by management through insider trades, or by lowering the value of outstanding equity through share repurchases. By contrast, the right-hand plot in Figure 1(a) presents a similar visualization for NonEGC firms that went public before the Act and had revenue below $\$ 1$ billion at IPO. ${ }^{17} \mathrm{We}$ do not reject the null of continuity as the $t$-statistic of the bias-corrected density is $-0.169(p$-value $=0.866)$. This implies no break in the float distribution of firms that did not have access to exemptions under Title I.

\section{--- Figure 1 ---}

We correct for potential manipulation of the float using an instrumental variables (IV) design. Since the LAF rule applies on the last day of the second fiscal quarter ( $L A F$ day), EGCs may try to manipulate their float via share repurchases prior to this day. However, there is less incentive for them to undertake such expensive efforts unless their float is near the LAF threshold in the immediate period preceding the LAF day. This is evident from the left-hand plot in Figure 1(b), which shows that EGCs are more likely to buy back shares during the six months leading up to the LAF day as their float nears or exceeds the $\$ 700$ million LAF cutoff. This tendency persists irrespective of the firm's age as a public company, meaning that continuous manipulation of the float is not very likely unless it is in the neighborhood of the LAF cutoff. The right-hand plot shows that share buybacks are much less likely during the six months after the LAF day. Furthermore, Figure A1 in the appendix shows there is no discontinuity in the float of an EGC exactly six months prior to the LAF day. In sum, these tests provide strong evidence that any float manipulation by an EGC firm occurs mostly near the LAF threshold during the six months leading up to the LAF day.

Based on these insights, we use a dummy variable PF700 that is equal to one if an EGC's float six months prior to the LAF day exceeds $\$ 700$ million, as an instrument for ExEGC. That is, ExEGC as of the LAF day in year $t$ is instrumented with PF700 six months prior. PF700 satisfies the two conditions required for a valid instrument. First, the float six months prior

\footnotetext{
17 This analysis also includes firms with revenue below \$1 billion that went public after the JOBS Act but opted out of EGC status.
} 
should strongly predict the float on the LAF day. This is evident from the scatterplot in Figure A2 showing a high correlation of 0.74 between $P F 700$ and ExEGC. Second, the instrument should have no direct bearing on the outcome of interest $Y_{t}$. The float at six months before the LAF day does not affect $Y_{t}$ at fiscal year-end except through the instrumented term ExEGC. The IV design is based on the below two-stage model:

$$
\begin{aligned}
E x E G C_{i, t} & =\alpha_{1} \cdot P F 700_{i, t, q-2}+\alpha_{2} \cdot X_{i, t}+\delta_{j}+\lambda_{t}+\varepsilon \\
Y_{t} & =\beta_{1} \cdot E x E G C_{t}+\beta_{2} \cdot X_{t}+\delta_{j}+\lambda_{t}+\varepsilon
\end{aligned}
$$

where $E \widehat{x E G} C_{t}$ is the predicted likelihood that the EGC I becomes an LAF in year $t . X_{i, t}$ denotes firm-level observables including financial characteristics, corporate governance, stock market conditions, and up to the cubic term of float. The coefficient $\beta_{1}$ represents the causal effect of EGC status loss on $Y_{t}$ under the identifying assumption that firms are comparable in both observable and unobservable characteristics around the LAF cutoff. $\delta_{j}$ and $\lambda_{t}$ are industry and year fixed effects, respectively. While it is impossible to evaluate whether firms around the treatment cutoff are similar in unobservable characteristics, we can still assess whether they are similar in their observable characteristics. In Figure A3 in the appendix, we plot observable EGC characteristics against the float, centered at the treatment cutoff. All the observable firm characteristics evolve smoothly over the entire range of the float, including near the cutoff.

\section{Sample and descriptive statistics}

\subsection{Data description}

To identify EGC firms, we gathered data on 5,186 completed IPOs of US firms between January 1, 2000 and April 30, 2019 from Capital IQ. Following earlier studies, we exclude IPOs of issuers classified as financial services firms, closed-end investment funds, holding companies, special purpose acquisition companies, and conglomerates. We also exclude rights offers, best-efforts offers, shell companies, and limited partnerships. This screening yields 3,595 IPOs. We then apply the following restrictions: (1) the IPO is listed on New York Stock Exchange (NYSE), Nasdaq, or American Stock Exchange (AMEX), (2) minimum offer value is $\$ 5$ million, (3) minimum issuer age is three years, (4) at least 30 days of price data is available with the Center for Research in Security Prices (CRSP) from the IPO effective date, and (5) 
duration between initial filing and offer completion does not exceed 18 months. We then exclude firms with annual revenue over \$1 billion at IPO as these would never have been eligible for EGC treatment. These steps yield a sample of 1,220 IPOs, of which 549 IPOs took place after the JOBS Act went into effect. We then retrieve S-1 filings for these IPOs from the SEC's Electronic Data Gathering, Analysis, and Retrieval (EDGAR) system. Following the JOBS Act, firms must explicitly state in their S-1 filings whether they do (not) qualify for EGC treatment. ${ }^{18}$ Figure A4(a) in the appendix plots the number of S-1 filings of completed IPOs per year-quarter. There is a notable rise in IPOs after the JOBS Act, and an overwhelming majority of them are by EGC firms. Manual inspection of the filings reveals 523 EGCs in the sample, representing $95.8 \%$ of all firms that went public after the Act.

Our primary goal is to understand the effects of mandatory disclosure brought about by the LAF regulation on EGCs' fundraising choices, investment policy, and future growth. For this purpose, we obtain firm-level data from CRSP/Compustat. We also collect float data for the sample firms from 10-K filings between the years 2000 and 2019. ${ }^{19}$ Firms that do not feature in Compustat are excluded. We then use a link table provided by WRDS to merge each 10-K filing with the corresponding firm-year observation in CRSP/Compustat using the central index key (CIK). Computing PF700, our instrument for ExEGC, is tricky as firms often do not report their float in quarterly 10-Q filings. We overcome this issue using data from Datastream and estimate $P F 700$ as the number of free float shares (NOSH * NOSHFF) times closing price (P) exactly six months prior to the LAF day of a given firm.

Our analysis focuses on firms with float between $\$ 350$ million and $\$ 1050$ million, which effectively minimizes any potential confounding by other regulations. ${ }^{20}$

\footnotetext{
${ }^{18}$ See Figure $\mathrm{C} 1$ for example of an S-1 filing for an IPO by an EGC firm.

${ }^{19}$ For firms with float missing in their annual $10 \mathrm{~K}$ filings, we use data from Refinitiv Eikon to manually compute float as the product of the aggregate outstanding shares held by non-affiliates (free float) and closing price of the stock on the last trading day of the second fiscal quarter of that year.

${ }^{20}$ These include (i) Scaled disclosure provisions introduced in 1992 for "small business issuers" with less than \$25 million float, (ii) "Non-accelerated filer" provisions enacted in 2002 that grant firms below \$75 million float 10(15) additional days to file quarterly (annual) statements with the SEC, (iii) SOX 404(b) that exempts firms below $\$ 75$ float from requiring firms to use an external auditor to attest their internal reporting controls, also introduced in 2002, (iv) "Smaller reporting company" (SRC) rule of 2008 that allows some flexibility in disclosure for firms below $\$ 75$ million float, and (v) "Accelerated filer" status for firms with annual revenue of $\$ 100$ million or more and float between $\$ 75$ and $\$ 700$ million (Among these, firms with float between $\$ 75$ and $\$ 250$ million are treated as SRCs while firms with float above $\$ 250$ million are not treated as SRCs, and are subject to higher disclosure requirements. These provisions apply only to NonEGC firms that went public before the JOBS Act).
} 
To investigate equity issuance by EGC firms, we use the variable New Equity denoting the dollar value of common stock issued by the firm via seasoned public offers (SPOs) during a fiscal year. To compute this variable, we collect data on all SPOs by US firms between January 1, 2000 and April 30, 2019 from Capital IQ and apply filters similar to those used in the IPO sample. Only SPOs that issue new primary stock independent of existing shareholders are included. ${ }^{21}$ In total, we have 3,207 SPOs: 2,336 SPOs by NonEGCs and 841 SPOs by firms that went public as an EGC. ${ }^{22}$ The SPOs are grouped by firm-year and gross proceeds aggregated to estimate New Equity. Furthermore, we manually scan the S-1 filing of each SPO to determine whether the issuer qualifies for EGC treatment when conducting the offer. ${ }^{23}$ It is important to verify this because a firm can lose its EGC status prior to the maximum allowed period of five years, notably if it becomes an LAF. ${ }^{24}$ Review of S-1 filings shows that of the 841 SPOs by firms that were an EGC at IPO, 593 SPOs were by EGC firms whereas 248 SPOs were by firms that no longer qualified for EGC treatment as they had become an LAF (i.e., ExEGCs). ${ }^{25}$ We also collect data on funds used to repurchase common stock (PRSTKCC), denoted by the variable Purchased Equity.

Debt issuance in a given year is represented by the variable New Debt. It is the total annual long-term debt issued (DLTIS), and covers bonds, notes, lease obligations, debt reclassifications, and acquisition loans. ${ }^{26}$

We also estimate the cost of equity and debt issuance. Raising equity through an SPO entails a number of expenses, which can be broadly categorized into direct and indirect costs. Direct

\footnotetext{
${ }^{21}$ In Appendix B, we compare US SPO activity around the JOBS Act with an international control sample that is constructed using a similar methodology based on data from Capital IQ. The analysis suggests a substantial rise in US SPO activity following the JOBS Act, with EGCs driving a substantial part of equity raising in this market. ${ }^{22}$ Stock tickers of SPO issuers were compared to the IPO sample to identify issuers that went public as an EGC. ${ }^{23}$ See Appendix C2 for example of an S-1 filing for an SPO by an EGC firm.

${ }^{24}$ Analysis of $10-\mathrm{K}$ filings reveals that the other two conditions that can lead to EGC disqualification, namely gross revenue exceeding $\$ 1$ billion in the most recent fiscal year and total non-convertible debt issued in the last three years exceeding $\$ 1$ billion, are rarely violated and hence not part of our analysis.

${ }^{25}$ Leary and Roberts (2005) and Cabezon (2020) define equity issuance as having occurred if the net change in common shares outstanding normalized by total assets in the previous year is greater than $5 \%$. However, a change in common shares comprises not only new common stock issued through a public offer, but also conversion of preferred stock/debt to common stock and the exercise of stock options and warrants. In unreported analyses, we use alternative measures of New Equity based on this definition and also the dollar value of common stock sold in a given year from Compustat (SCSTKC). The results are consistent with our main findings, suggesting that conversions to common stock do not significantly impact the float.

${ }^{26}$ Item names in brackets refer to Compustat data items.
} 
costs mainly comprise the fees charged by underwriters for conducting the SPO, and are available from Capital IQ. Accordingly, we measure Direct Equity Costs as the sum of underwriting, legal, and other fees charged by intermediaries involved in an SPO scaled by offer proceeds. Indirect equity issuance costs, also known as underpricing, are the discounts offered by issuers on the offer price as compensation for the uncertainty and information asymmetry faced by investors during the offer process (Sherman and Titman, 2002). Underpricing also helps relieve any temporary price pressure resulting from the issue of a large block of new shares, and is used as a "sweetener" to entice investors to buy shares in the SPO (Corwin, 2003). Following Corwin (2003), we estimate Indirect Equity Costs as minus one times the difference between previous day's closing price and the SPO offer price, scaled by the previous day's closing price. Data on SPO offer price is from Capital IQ whereas closing price and aftermarket information on the underlying stock is from CRSP.

Estimating annual debt costs is more straightforward. Following Frank and Shen (2016), we measure Debt Costs using Compustat data as annual interest expense (XINT) divided by longterm debt (DLTT) plus debt in current liabilities (DLC). ${ }^{27}$

Our study covers both internal and external investments. We use Compustat data to estimate internal investments made by firms that comprise capital expenditures (Capex, CAPX), R\&D expenses (RD, XRD), and employee headcount (Employees, EMP). Capex and $R D$ are set to zero wherever data is missing. Besides investing internally, firms can make external investments via acquisitions to grow and expand. We capture the M\&A activity of firms using Capital IQ data. The external investment measures considered are the number and dollar value of acquisitions by the firm during a year, as well as the percentage of transactions financed entirely by cash against some combination of cash and stock.

We follow prior literature and control for various firm-level characteristics that are typically associated with fundraising, financial constraints, and investment policy. We also control for firm size (total assets), age, and the quality of corporate governance proxied by board size and independence. Data for these are obtained from Compustat and BoardEx. All the variables are winsorized for outliers at the $1 \%$ and $99 \%$ levels.

\footnotetext{
${ }^{27} \mathrm{We}$ are unable to estimate debt issuance costs at the loan level since these are issued mostly in private (e.g., bank loans) and are seldom disclosed individually in quarterly/annual filings.
} 
One of the main objectives of the JOBS Act was to alleviate the problems faced by highgrowth companies in accessing external funds, mainly by encouraging them to go public. This is a key focus of our investigation. For this purpose, we split EGCs into low-growth and highgrowth firms based on their Tobin's $q$ value on the first day of the IPO. Following Kaplan and Zingales (1997), we measure Tobin's $q$ as a ratio of the market value of assets divided by book value of assets, where the former is computed as book value of assets plus the market value of common stock less the sum of the book value of common stock and deferred taxes. ${ }^{28}$

A Tobin's $q$ above one (high- $q$ ) implies that the firm has more valuable growth opportunities as seen by outside investors, whereas a Tobin's $q$ below one (low- $q$ ) denotes the opposite with the stock trading below the cost to replace the firm's assets. Figure A4(b) in the appendix plots the number of low- $q$ and high- $q$ EGC firms going public each year. High- $q$ firms dominate the cohort of EGCs going public in any given year. Especially during the initial years after the Act (q1'2012-q4'2014) the number of high- $q$ EGCs going public was up to three times as high as low- $q$ EGCs. This result is consistent with Dambra, Field and Gustafson (2015), who find a significant rise in IPO activity in the biotech/pharma sectors during the first two years of the Act. However, our study goes a step further by measuring growth opportunities at the firmlevel and differentiates between low- $q$ and high- $q$ firms within each industry. ${ }^{29}$

\subsection{How significant is the LAF regulation for EGC firms?}

By passing Title I of the JOBS Act, policymakers had hoped that unburdening firms for a limited period from costly disclosure requirements would encourage them to go public. Although firms going public after the Act have overwhelmingly opted for EGC status, whether they remain qualified for disclosure and compliance exemptions for the maximum five-year

\footnotetext{
28 Specifically, for firm $i$ in year $t$,

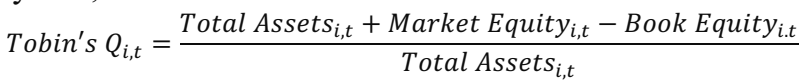

where Total Assets $i, t$ is the reported book value of assets, Market Equity ${ }_{i, t}$ is stock price multiplied by common shares outstanding, Book Equity int $_{\text {is }}$ is shareholder equity plus deferred taxes plus investment tax credits less preferred stock, as reported in the balance sheet. Consistent with extant literature, book values are as reported for a fiscal year (from Compustat) whereas market value of equity is as reported at calendar year end (from CRSP). ${ }^{29}$ Figure A4(b) further shows there is no significant difference in IPO activity between low- $q$ and high- $q$ firms in the years preceding the JOBS Act (q1'2000-q1'2012). This evidence shows that the type of firms entering public markets has fundamentally changed following enactment of the JOBS Act. See also the difference in Tobin's $q$ between EGC (at IPO) and NonEGC firms in Table A1 in the online appendix.
} 
period remains unclear. Principal among the conditions that would make an EGC ineligible for these exemptions is the $\$ 700$ million LAF threshold. Crossing this threshold means that the firm will cease to be an EGC and is treated thereafter as an LAF subject to mandatory disclosure during financial reporting and while raising public equity.

--- Figure 2 ---

To address the question whether EGCs utilize the full scale of exemptions available to them under the JOBS Act, we measure the duration (in quarters) between the IPO date of an EGC and the date on which it becomes an ExEGC, i.e., subject to the LAF regulations. Figure 2(a) plots the distribution of this duration for 248 EGCs that lost their exemptions either owing to the LAF rule or upon completing the maximum treatment period of five years. The duration varies widely from one quarter for some EGCs to up to 21 quarters. Importantly, the mean EGC duration is only 8.5 quarters with nearly $47 \%$ of them (i.e., $22.3 \%$ of all 523 firms in our sample that went public as EGCs) losing exemptions within the first year of the IPO. Figure 2(b) presents violin plots of EGC duration by IPO year, which paint a similar story of underutilization of exemptions. Lastly, Figure 2(c) shows box plots of EGC duration among high- $q$ and low- $q$ EGC firms (based on Tobin's $q$ at IPO). While median EGC duration is low and similar across both groups at 4.5 quarters, high- $q$ EGCs generally remain exempt for longer periods than their low- $q$ peers. One possible explanation for this discrepancy is that because high- $q$ firms have greater financing needs, they have incentives to prolong EGC status for as long as possible to be able to raise more equity under the on-ramp provisions. Overall, these findings suggest that the majority of EGCs lose their disclosure exemptions within a short span of going public and that very few are able to utilize exemptions for longer periods.

What happens when a firm loses its EGC status? The $\$ 700$ million LAF threshold poses a Catch-22 situation for EGC firms. On one hand, a natural objective of managers is stock price appreciation as it is tied to shareholder value, better executive pay, and the early exercise of stock options (Knopf, Nam and Thornton Jr, 2002). Higher stock prices further encourage firms to "time" the market and raise funds by issuing more stock through an SPO (Baker and Wurgler, 2002; DeAngelo, DeAngelo and Stulz, 2010; Kim and Weisbach, 2008). On the other hand, pursuing these goals could push an EGC over the LAF threshold, triggering an immediate escalation of disclosure requirements and related costs. This also poses another issue because 
the inability to utilize EGC provisions for the maximum duration may dissuade other firms from going public, thereby impeding the hoped-for revival of US public markets.

\subsection{Descriptive statistics}

Panel A of Table 1 reports summary statistics on EGC firms during the phase where they are exempt from mandatory disclosure. Panel B provides similar statistics for ExEGC firms that have crossed over into the mandatory regime under LAF. The mean EGC duration is 8.5 quarters, which is well below the maximum allowed exemption period of 5 years. During their years as an EGC, firms had a median float of \$441 million, assets worth \$116 million, annual sales of $\$ 87$ million, and 791 employees. Among these, assets and sales increase significantly in the aftermath of an EGC's transition to ExEGC status. EGCs carry low debt burden with the mean debt-to-assets $(\mathrm{Debt} / \mathrm{TA})$ ratio at 18\%. The mean Debt/TA among ExEGCs is higher by only $3 \%$. Equity issuance among EGCs is modest during their exempt phase with a mean of $\$ 23.5$ million, and increases by over three-fold upon their move to the mandatory setting. Debt issuance also exhibits a similar trend. Note however that the median equity and debt issuance per year are zero. This means only a fraction of EGCs are actively raising funds after their IPO.

\section{--- Table 1 ---}

The mean Tobin's $q$ of an EGC is 1.42, and 1.66 in the case of ExEGCs. This indicates that there are renewed growth opportunities by EGCs after their switch to the LAF regime. EGCs have mean sales-to-assets and return-on-assets (ROA) ratios of 59\% and $-21 \%$, respectively, and a profit margin below zero in nearly two-thirds of observations. These factors improve significantly once an EGC is no longer exempt, suggesting that the firm becomes operationally more efficient upon becoming subject to mandatory disclosure. Surprisingly, capital expenditures (Capex) and investments in property, plant, and equipment (PPE), relative to sales, are rather low among EGCs at a mean of $8 \%$ and 33\%, respectively. R\&D-to-sales among EGCs is high with a mean of $113 \%$ but is lower by more than half among firms in the ExEGC category. EGCs also actively pursue external growth opportunities. The median EGC makes at least one acquisition per year, spending a median of up to $\$ 71$ million in this process. However, EGCs pursue fewer external growth opportunities after becoming compliant to mandatory disclosure, as evidenced by the much lower values of acquisitions made by ExEGCs. 


\subsection{Fundraising sensitivity to the LAF rule}

If EGCs intend to evade mandatory disclosure costs imposed by the LAF regulation, we should see evidence of a drop in equity issuance, and possible replacement of equity with debt financing, as their float nears the LAF cutoff. To investigate this, we plot the distribution of fundraising by firms around the LAF cutoff in Figure 3. Panel (a) shows a local polynomial regression plot of equity and debt issuance by firms that went public as an EGC against their float. Equity issuance (New Equity) is positively related to the float up to $\$ 500$ million, but then drops steeply until the LAF cutoff, and picks up once again after the cutoff. We also examine Net Equity Issuance, defined as the difference between New Equity and Purchased Equity in a given year. Net Equity Issuance drops more steeply relative to equity issuance just before the cutoff, but is flatter beyond the cutoff. These findings indicate that EGCs raise follow-on equity as long as their float remains well below the cutoff. However, to avoid losing exemptions, EGCs issue less equity and repurchase shares as their float nears the LAF cutoff. On the contrary, debt issuance exhibits a jump just before the cutoff, suggesting that EGC firms that face a threat of exemption loss are partially substituting equity with debt financing.

\section{--- Figure 3 ---}

Panel (b) shows plots of equity and debt issuance for our placebo sample of NonEGC firms, that is, firms which went public before the JOBS Act. There is no major difference in equity and debt issuance among NonEGCs in the neighbourhood of the cutoff $(\$ 500 \mathrm{~m}, \$ 900 \mathrm{~m})$, implying that they are not affected as much by the LAF rule. This is not surprising as NonEGC firms with a float exceeding \$250 million are automatically classified as "accelerated filers" subject to strict disclosure. A subsequent transition to LAF status is unlikely to cause a major rise in the disclosure requirements of these firms.

Together, these results establish that equity raising by EGCs is sensitive to the float, especially near the LAF cutoff. Besides repurchasing shares, EGCs also attempt to stay below the cutoff and prolong the disclosure exemptions available to them by issuing less equity.

\section{Results}

4.1. Equity and Debt Issuance 


\subsubsection{Main Results}

Figure 4 visualizes the fuzzy RD design based on equations (2.2). To isolate the effects of mandatory disclosure on fundraising by EGC firms as precisely as possible, we focus on a restricted sample of firms with float between $\$ 350$ and $\$ 1050$ million (i.e., within $\$ 350$ million on either side of the LAF cutoff). This effectively allows us to compare the treatment effect $\beta_{1}$ between EGC and ExEGC firms while minimizing confounding biases.

Each plot in Figure 4 relates a firm's annual equity issuance to its float. The left-hand plots compare equity issuance among EGC and ExEGC firms, while the right-hand plots show the same for a placebo sample of NonEGCs. Local linear regressions are fit on either side of the LAF cutoff in each plot. Comparison of the plots indicates that EGCs raise considerably more equity (in dollar terms) than NonEGC firms. The first left-hand plot shows that equity raised (in dollars) among ExEGCs rises with a sharp discontinuity at the cutoff compared to EGCs that stay exempt. The right plot shows no such discontinuity among NonEGCs. Plot (b) shows the corresponding graphs of equity issuance scaled by lagged assets. There is a small discontinuous rise in scaled equity issuance among ExEGC firms, but not among NonEGCs.

Figure 5 plots debt issuance versus float for the firms in our sample. The value of debt raised per year is comparable across EGC and NonEGC firms, both in absolute terms and when scaled by lagged assets. This suggests that debt issuance rises sharply when firms become ExEGCs.

--- Figures 4 and 5 ---

Table 2 presents RD estimates of the change in equity and debt issuance when EGCs move from being exempt to mandatorily disclosing under the LAF rule. Equity issuance is measured in two ways: the natural log of one plus New Equity (models 1-4) and New Equity scaled by lagged total assets (models 5-8). Similarly, debt issuance is measured as the natural log of one plus New Debt (models 9-12) and New Debt scaled by lagged total assets (models 13-16). We use a narrow bandwidth $h$, chosen using the rdbwselect Stata command that identifies an optimal bandwidth with the least mean squared error for a given sample (Calonico, Cattaneo and Farrell, 2018; Calonico, Cattaneo, Farrell and Titiunik, 2017). ${ }^{30}$ This procedure yields an

\footnotetext{
${ }^{30}$ We use heteroskedasticity-robust standard errors and a triangular kernel, which weights the data by its distance to the cutoff within the selected bandwidth.
} 
optimal bandwidth range of $\$ 250$ to $\$ 350$ million. For robustness, our analysis uses the smallest bandwidth in this range: $\$ 250$ million. ${ }^{31}$ The first two regression results under each outcome of interest are OLS estimates. All our specifications include year and industry (SIC) fixed effects, and a flexible functional form of the float.

The coefficient of ExEGC in model 1 is positive and significant $(\mathrm{p}<0.001)$. In model 2, we control for several firm characteristics. These include lagged total assets and headcount as proxies for firm size, lagged debt-to-assets ratio as proxy for balance sheet risk, cash by lagged assets to proxy the firm's ability to meet short-term obligations, lagged capex and R\&D expenses, scaled by assets, to proxy investment intensity and riskiness of the firm, firm age, and Tobin's $q$ as a proxy for growth opportunities. We also control for stock market conditions using the lagged mean twelve-month buy and hold return on all Nasdaq stocks (Stock Market Return) and a dummy representing hot (cold) IPO market conditions (Hot SPO Market). The coefficient of ExEGC remains significant even after inclusion of these controls.

--- Table 2 ---

It is likely that EGCs will manipulate their float in an attempt to stay below the LAF cutoff. If this is true, the OLS estimates will underestimate the true effect of EGC status loss because they cannot distinguish between EGCs that did, or did not, avoid compliance with the LAF regulation. We address this concern using the IV method described in equations (2.1) and (2.2), where the loss of EGC status $(E x E G C)$ is instrumented with a PF700 dummy denoting whether the firm's float six months prior exceeded $\$ 700$ million. Models 3 and 4 present the IV estimates for Log (New Equity). The first stage is estimated using a linear probability model. The partial $F$-statistic has a minimum value of 27.1 , implying strong instrument choice. The instrumented ExEGC has much smaller coefficients than the OLS results, which are statistically insignificant. The difference between the OLS and IV estimates confirm empirically that while EGCs continue to raise equity even after becoming fully reporting companies, many manage to remain exempt by curtailing equity issuance and by manipulating their float.

The results are quite similar when equity issuance is measured as New Equity scaled by lagged assets (models 5-8). The OLS estimates show a 30.1\% increase in equity raised by EGC

\footnotetext{
${ }^{31}$ Additional robustness tests using larger bandwidths of $\$ 300$ and $\$ 350$ million are available in Table A4 in the online appendix.
} 
firms after they move to a mandatory setting. Contrastingly, the IV estimates point to a drop of $14 \%$ in equity issuance among EGCs undergoing this transition, but are not significant. For the median EGC with \$116 million in assets, the IV estimates indicate a drop of \$16.2 million in equity issuance following loss of disclosure exemptions. This conflicting evidence provides further proof of manipulation of the float by EGC firms.

There is also a marked difference in debt issuance among EGCs around the cutoff. OLS results in models 9 and 10 suggest that EGCs raise more debt after transitioning to full disclosure. The corresponding IV estimates in models 11 and 12 show that the increase in debt issuance is, in fact, much greater. These findings are robust to alternate measures of debt issuance scaled by lagged assets (models 13-16). Specifically, the coefficient of ExEGC in model 15 suggests that debt issuance increases by 39.5 million for the median EGC with $\$ 116$ million in assets after it switches to mandatory disclosure.

Overall, our analysis shows strong evidence that EGCs anticipating loss of exemptions take steps to evade compliance with the LAF regulation. These steps aimed at reducing the float include share repurchases and the increased use of debt capital for corporate activities.

\subsubsection{Within-Firm Analysis}

The results thus far have shown that EGC firms raise more equity than NonEGCs, but tend to rely marginally on debt financing when faced with the risk of moving towards mandatory disclosure. However, one could still be concerned that these cross-sectional estimates do not fully capture the causal effects of the LAF regulation on fundraising by EGC firms. One reason is that comparing outcomes on either side of the cutoff within a narrow bandwidth $h$ does not fully account for changes in fundraising by a firm whose float is consistently on one side of the cutoff. It is also unclear how quickly EGCs move to take advantage of their exemptions and raise more funds, especially public equity, while being free from full disclosure.

This section addresses these concerns by measuring changes in equity and debt issuance among EGC firms that transition towards becoming ExEGCs in the years following their IPO. These estimates control for various firm and market characteristics, thus minimizing the chances that our results are driven by omitted variable bias.

The left-hand plot in Figure 6(a) shows the fraction of firms raising equity during the first 
six years of going public as an EGC. This fraction rises from $35 \%$ in the first year to a peak of $44 \%$ in the following year. It then begins to fall steeply in the years thereafter, reaching a low of $20 \%$ by year six. The right-hand plot in Figure 6(a) shows the fraction of firms raising debt each year after going public as an EGC. This trend is more stable than for equity raised by the same firms. It drops from $38 \%$ during the IPO year to $33 \%$ by year one, rising gradually thereafter to $43 \%$ by year five. ${ }^{32}$ These plots provide preliminary evidence that firms going public under EGC treatment raise equity more frequently during their first two years as a public company, whereas their debt issuance increases only slightly from year three onwards. ${ }^{33}$

$$
\text { --- Figure } 6 \text {--- }
$$

We formally test the relation between EGC status and fundraising over time by running OLS panel estimates on the full sample ( $h=\$ 350$ million) with industry-year fixed effects and firmclustered standard errors. To understand the fundraising pattern among EGCs conditional on their disclosure status, we construct individual age dummies for each year the firm has been a public company. All specifications include industry-year fixed effects. We do not include firm fixed effects as age is correlated with firm and year fixed effects. Models 1-3 in Table 3 present regressions of a dummy denoting equity issuance in a given year on the individual age dummies (with the IPO year serving as the omitted base variable), a dummy indicating whether the firm is no longer an EGC $(E x E G C)$, interactions between the age dummies and $E x E G C$, and relevant control variables. Models 2 and 3 add several firm characteristics including size (assets) up to the quadratic polynomial. Model 3 also controls for stock market and macroeconomic factors.

$$
\text { --- Table } 3 \text {--- }
$$

The constant term in model 1 suggests that $42.6 \%$ of EGCs raised follow-on public equity in the same year that they went public. From this base of $42.6 \%$, the estimated probability of raising equity remains steady for the first year, but then drops by up to $33.7 \%$ by year three in model 3. The standard errors rise considerably during later years, possibly due to a drop in

\footnotetext{
${ }^{32}$ Figure A5(a) in the online appendix shows that the trend is much lower among NonEGC firms, as only up to $15 \%$ of them raise equity in any given year. Figure A5(b) in the appendix shows that debt raising among NonEGCs increases more steadily, starting with 35\% of them raising debt in the IPO year and up to $47 \%$ by year ten.

${ }^{33}$ Note that the plots in panel (a) of Figure 6 merely plot raw means from an unbalanced panel of firms that went public under EGC treatment. The distribution of these firms in the sample changes over time, and no correction is made in the plots for changes in firm characteristics such as size and EGC status.
} 
observations as many EGCs in our sample have lower listing age since they went public several years after the JOBS Act took effect. Consistent with the findings in Table 2, ExEGC is positive with a minimum of $2.5 \%$ (model 3). Interaction terms between ExEGC and the year dummies show that equity issuance is marginally higher among ExEGCs, but not statistically significant except in year three. For better interpretation, we plot the coefficients of these interaction terms in the left-hand plot in Figure 6(b). Firms under EGC status are most likely to issue equity within the first two years of going public. Equity issuance drops afterwards and generally remains low, possibly because some EGCs try to stay below the LAF limit and prolong their exemption period. The propensity to raise equity is slightly higher among ExEGCs, possibly because of their greater financing needs (most of them are high- $q$ firms at IPO) and also because mandatory disclosure is known to lower the cost of capital (Jensen and Meckling, 1976).

Models 4-6 in Table 3(b) present the OLS estimates for debt issuance. The interaction terms between $E x E G C$ and individual year dummies suggest that the propensity to raise debt by listing age is not very different among EGC and ExEGC firms until year four. In subsequent years, debt issuance drops among EGCs but increases among ExEGCs. These results corroborate our earlier findings that EGCs raise more debt after they become mandatorily disclosing. This pattern emerges only a few years after the IPO when the firm is most likely no longer an EGC and is also possibly less debt-constrained. Plotted coefficients of the interaction terms in the right-hand plot in Figure 6(b) confirm our interpretations. ${ }^{34}$

\subsection{Investments}

In addition to impacting fundraising decisions, changes in disclosure obligations can influence investment policy. This is an important question to investigate because a sudden change in compliance will likely divert managerial attention away from new investment towards fulfilling reporting duties and quarterly targets. The increased burden to being public under LAF requirements could therefore impact significantly on the investment policy of EGC firms. We expect these effects in both the internal and external investments pursued by EGC firms, and investigate these separately.

\footnotetext{
${ }^{34}$ As a robustness check, we run the analysis for smaller bandwidths of the float $(h)$ ranging from $\$ 150$ to $\$ 300$ million. These estimates are consistent with our main results in Table 3, and are presented in Table A5.
} 


\subsubsection{Internal Investments}

We consider four types of internal investments: capital expenditure (Capex), investments in property, plant, and equipment $(P P E), \mathrm{R} \& \mathrm{D}$ expenditure $(R \& D)$, and number of employees (Employees). ${ }^{35}$ Each measure is standardized by lagged total sales. Missing values are replaced by zero to prevent a reduction in sample size. Table 4(a) reports the regression estimates for equations (1) and (2) for each of these investment measures. The OLS coefficients of ExEGC are generally negative except for R\&D but are not significant. The IV estimates are however significant up to the $1 \%$ level. Causal inference of the IV estimates suggests that capital expenditure drops by $19 \%$ and R\&D by $14 \%$ when the EGC moves from being exempt to a mandatory disclosure setting. Investments in PPE and employees also experience a drop upon the firm's move to ExEGC status. The drop in internal investments shows that ExEGCs tend to focus more on assets in place and innovate less than EGCs.

--- Table 4 ---

We next investigate whether changes in disclosure requirements affect how EGCs allocate capital to their various investment activities. This is an important question as prior literature notes that better disclosure improves external monitoring by investors and thus leads to greater investment efficiency (Cho, 2015; Francis, Huang, Khurana and Pereira, 2009; Leuz and Wysocki, 2016). To investigate this question, we regress the one-year forward change in each scaled investment measure on ExEGC, log dollar values of equity and debt issuance (lagged), and their interaction terms. Each specification includes the usual set of controls along with industry and year fixed effects, and firm-clustered standard errors. The results are reported in Table 4(b). Coefficients of equity issuance are all negative and highly significant in the IV estimations. Contrastingly, the interaction terms between equity issuance and ExEGC have positive and significant coefficients. These results imply that EGCs are less likely to use equity to finance investments in physical assets, $R \& D$, or hiring while they remain exempt. In comparison, debt has a much weaker positive effect on capex when the EGC is exempt from the disclosure burden. This could be because EGCs are credit-constrained as they have fewer assets that can be used as collateral, have less cash, and are less profitable when operating under less disclosure (see Table 1). At the same time, disclosure-exempt access to public equity

\footnotetext{
${ }^{35}$ Number of employees is expressed in millions to make it convenient for scaling by lagged total sales.
} 
markets may reduce an EGC's dependence on debt to fund its investment policy. The non-use of debt to fund $R \& D$ is consistent with prior literature which states that innovation, especially in younger firms, is financed mainly with equity (Brown, Fazzari and Petersen, 2009). Debt issuance has a negative, but insignificant, effect on hiring. This is in line with available literature which states that debt leads to a reduction in employment and wages (Hanka, 1998).

\subsubsection{External Investments}

An important consequence of the disclosure relief granted by the JOBS Act is that EGC firms are associated with a high degree of information asymmetry and greater post-IPO share price volatility (Barth, Landsman and Taylor, 2017). A greater uncertainty over the true value of the firm raises prospects that the firm may be overvalued (Purnanandam and Swaminathan, 2004). Overvaluation incentivizes managers to pursue acquisitions, mainly since an overvalued stock lowers takeover costs and impedes the market's ability to value potential synergies from such deals (Shleifer and Vishny, 2003).

These facts suggest a connection between firm-level disclosure and the willingness to pursue acquisitions. While regulatory concessions under the JOBS Act should encourage stronger acquisition activity among EGCs, this trend is likely to reverse following their move to a mandatory regime. The resulting administrative burden could also shift managerial attention towards compliance and governance, while also diverting resources away from acquisitions, which are often riskier and complex to assess than internal investments. The rise in disclosure costs following loss of EGC status is thus likely to impose restrictions on firms' resources and their appetite for risk, forcing managers to pursue fewer acquisitions.

Results in Table 5 confirm this hypothesis. We use three proxies to capture the acquisition activity each year: a dummy indicating if the firm made at least one acquisition (Acquisition), the log dollar value of acquisitions (Acquisition Value), and a dummy equal to one if all acquisitions are paid for entirely in cash (All Cash Acquisitions). The regressions include our usual set of controls and industry/year fixed effects, with firm-clustered standard errors.

--- Table 5 ---

Both the OLS and IV results in part (a) show significant decline in acquisition activity following loss of EGC status. Coefficients of ExEGC in the IV regressions are all significant 
below the $1 \%$ level. The IV estimates in model 2 indicate that the mean EGC firm is $18 \%$ less likely to acquire after its transition to mandatory disclosure. ${ }^{36}$ Models 3-4 show a corresponding drop in the aggregate dollar value of acquisitions. This decline is however not economically significant. Further, model 6 shows that firms are $15 \%$ less likely to choose cash as a payment method to acquire, conditional on EGC status loss. Prior literature notes that cash enables quicker deal completion, eases bidding competition, and lowers the risk of bid rejection by the target management (Fishman, 1989). Using stock as acquisition currency is likely to increase deal uncertainty, and cause substantial delays due to stock registration and shareholder approval requirements (Gilson and Black, 1995). It follows that EGCs prefer cash as a payment method for acquisitions because it allows them to mitigate these frictions and be competitive. Given that EGC firms are associated with high stock price volatility (Barth, Landsman and Taylor, 2017), using cash to pay for acquisitions is also consistent with their demand for greater uncertainty aversion.

Table 5(b) investigates whether our sample firms time their fundraising to coincide with periods of acquisition activity. We find no significant relation between funds raised in a given year and subsequent acquisition activity of EGC firms. ${ }^{37}$ In contrast, ExEGCs raise cash via SPOs at least to partly fund acquisitions. These results suggest that strict disclosure enhances transparency, and therefore creates stronger incentives for firm managers to allocate their capital more efficiently. Another contributing factor is that it is much cheaper and easier for firms to raise equity when operating under full disclosure. ${ }^{38}$ Debt, on the other hand, does not appear to have any comparative influence on the acquisition activity of EGC firms.

\subsection{Growth Opportunities and Firm Value}

To the extent that disclosure serves as a monitoring mechanism, a drop in disclosure quality

\footnotetext{
${ }^{36}$ In unreported analysis, we run logit regressions on our dichotomous dependent variables Acquisition and All Cash Acquisitions, and obtain similar results. These are available upon request.

${ }^{37}$ One might argue that the cash used as acquisition currency is raised many years in advance at the IPO and in subsequent SPOs. We find no evidence to this effect in unreported analysis among the firms in our sample.

${ }^{38}$ Panel A, part (c) of Table A3 in the appendix offers descriptive evidence to support this hypothesis. The mean fees levied by underwriters of SPOs drop from 2.71\% (relative to offer size) for EGC firms to 1.7\% for ExEGCs. Similarly, money left on the table by an issuer when conducting an SPO (underpricing) is $7.7 \%$ of offer size among EGCs, but only 3.6\% among ExEGC firms. These statistics suggest a significant drop in equity issuance costs following an EGC's transition to full disclosure status.
} 
could incentivize managers to make suboptimal, self-maximizing decisions. These decisions could include suboptimal investments that reduce operating performance and firm value. Managers make such decisions because investors cannot properly link managerial decisions to firm performance or value when disclosure quality is low (Hope and Thomas, 2008).

It follows that a switch to mandatory disclosure should improve investors' ability to monitor managerial actions, leading to better recognition of growth opportunities and an overall improvement in firm value. Relatedly, the drop in internal and external investments upon EGC status loss signals a shift in managerial focus towards exploiting assets in place and achieving better efficiency, resulting in valuation benefits from full disclosure.

Figure 7 confirms that this is indeed the case. Panel (a) shows the non-parametric relation between growth opportunities, proxied by Tobin's q, and Listing Age. The relation is negative in the case of EGCs but is rather flat among ExEGC firms. These relations hold even after we control for firm characteristics and compute residuals from an OLS regression of Tobin's $q$ on $E x E G C$, firm-level controls, and industry-year fixed effects. The non-parametric relation between the residuals and listing age is negative only in the case of EGC firms.

$$
\text { --- Figure } 7 \text {--- }
$$

To empirically test the relationship between EGC status and Tobin's $q$, we run OLS and IV panel regressions that include the logarithm of listing age, Log (Listing Age), and an interaction term between ExEGC and Log (Listing Age) as regressors. These regressions control for industry-year fixed effects with firm-clustered standard errors. Note that since age is collinear with both year and firm fixed effects, the latter are not included (Loderer, Stulz and Waelchli, 2017). The results are reported in Panel A of Table 6. ${ }^{39}$ Models $1-2$ show that the Tobin's $q$ ratios of ExEGCs are significantly higher than for EGC firms. The higher Tobin's $q$ is consistent with investors perceiving managers of ExEGC firms to make more value-adding decisions than their exempt EGC peers. Log (Listing Age) has positive coefficients but is not significant. Lastly, the interaction term between ExEGC and Log (Listing Age) are negative

\footnotetext{
${ }^{39}$ Note that since we include firm size (logarithm of total assets) as a control variable, our results do not indicate declining returns to scale. Using alternative proxies for firm size, such as logarithm of total sales, yield consistent results. In unreported analysis, we obtain qualitatively similar results when using an alternative age measure proposed by Pástor and Veronesi (2003), namely, $\frac{-1}{(1+\text { Listing Age })}$.
} 
and significant at the 5\% level. This suggests that managers of firms subject to greater disclosure obligations tend to devote more efforts to existing assets, leading to only a marginal drop in their Tobin's $q$ over time. Once again, the OLS coefficients are smaller in magnitude than the IV estimates, consistent with EGC firms' efforts to remain below the LAF threshold.

--- Table 6 ---

A puzzling implication of the relation between EGC status and Tobin's $q$ is that disclosureexempt firms are unable to sustain their initial success, despite the fact that they tend to invest relatively more in R\&D and in buying other companies and technologies. We follow Loderer, Stulz and Waelchli (2017) and use a slightly different approach to shed light on this phenomenon. First, to eliminate common effects, we regress $q$ on firm size as well as industry and year fixed effects to estimate the residuals. We then compare this residual $q$ against the residual $q$ in year zero when the firm went public (denoted $q_{o}$ ). Panel (b) of Figure 7 plots the fraction of firms that exceed $q_{o}$ as a function of listing age and EGC status. Very few EGC firms have managed to exceed $q_{o}$ after year two. By age four, only $46 \%$ of EGCs have a Tobin's $q$ exceeding $q_{o}$. In line with previous findings, the fraction of ExEGCs with a $q$ larger than $q_{o}$ is always higher than that of EGC firms. Panel B of Table 6 presents formal analysis of firms' ability to renew their initial success at creating value. The dependent variable is a dummy equal to one if the Tobin's $q$ of the firm exceeds $q_{o}$, and zero otherwise. Both regressions include our usual set of controls, industry-year fixed effects, and firm-clustered standard errors. The evidence shows that ExEGCs have a greater propensity to revert to initial success $q_{o}$ compared to their exempt peers. However, this propensity declines with listing age.

\subsubsection{Which Factors Affect Growth Opportunities?}

So far, we have argued that EGC firms are less capable of renewing growth opportunities (known to outside investors) as long as they remain exempt from full disclosure. Panel (a) of Table 7 considers both equity and debt issuance and investigates how the raising of these funds impacts the growth opportunities of a firm conditional on its status as an EGC or ExEGC.

Model 1 shows a positive relation between equity raised by the firm in a given year and its Tobin's $q$ in the following year. Debt has a negative effect on Tobin's $q$. However, neither effect is statistically significant. In model 2 , we interact measures of equity and debt issuance 
with the ExEGC dummy. Coefficients of the main terms representing equity and debt issuance are negative, implying that fundraising under reduced disclosure is associated with the lower Tobin's $q$. On the other hand, the interactions suggest that equity raised by ExEGCs contributes to a marginally higher Tobin's $q$, whereas debt has no significant marginal effect on firm growth. The corresponding IV estimates in models 3 and 4 are qualitatively similar. Marginal effects analysis of model 4 suggests that a one standard deviation increase in equity issuance leads to a rise of 1.81 in the Tobin's $q$ of an ExEGC the following year compared to a similar EGC firm. A one standard deviation increase in debt leads to a marginal increase of only 0.85 in the Tobin's $q$ of an ExEGC next year relative to a similar EGC peer.

Together, these results highlight that funds raised are negatively related to firm value for EGCs as opposed to ExEGCs. The public equity raised by an EGC is most likely done under the disclosure and compliance provisions of the JOBS Act, which potentially reduce the scope and credibility of information revealed to investors at the time of the issue. This makes it difficult for investors to monitor the use of proceeds or determine their contribution to the growth of the firm, thereby creating the perception that equity raised by an EGC is rather valuereducing compared with ExEGCs. These arguments are justified by the fact that equity issuance is positively related to next year's Tobin's $q$ among ExEGCs. Moreover, our earlier analysis showed that firms tend to exploit their existing assets rather than pursue new investment opportunities after they become an ExEGC (See Table 6). Investors should therefore expect ExEGCs to better utilize the equity raised through an SPO compared to their exempt EGC peers, as reflected in their different Tobin's $q$ ratios. ${ }^{40}$ The negative relation between debt and Tobin's $q$ of an EGC is consistent with the market facing difficulties in linking the use of debt proceeds to future performance and growth when the firm is making fewer financial disclosures. Thus, even if EGCs were to turn to private debt markets with the intent to avoid revealing firm-specific information via public disclosures, our results show that this has adverse consequences in the form of an overall reduction in firm valuation.

--- Table 7 ---

\footnotetext{
${ }^{40}$ Note that these differences in investor beliefs are also evident in the costs levied on equity and debt issuance conditional on the firm's disclosure. Panel (c) of Table A3 in the online appendix shows that the cost of raising either equity or debt reduces when the EGC moves into the mandatory regime.
} 
Although the above results improve our understanding of how disclosure affects firm value through the external financing channel, they do not capture the specific investment channels that influence the growth opportunities of a firm. We posit that an increase in capital spending will positively affect firm value depending on the market's ability to assess investment opportunities based on financial disclosures made by the firm (proxied by EGC status). Panel (b) of Table 7 explores which investment policies affect the market's assessment of future growth opportunities, as proxied by Tobin's $q$. Models 1-3 consider internal investments made by firms (capex, PPE, and R\&D, all scaled by lagged sales). Models 4-6 cover external investments made in the form of acquisitions. We find that internal investments exert a negative impact on Tobin's $q$ among EGC firms, which is not significant. The effect reverses in the case of capex and PPE, but not R\&D, once an EGC becomes fully disclosing. This evidence is consistent with future benefits produced by investments in R\&D being more uncertain than those made in capex/PPE (Kothari, Laguerre and Leone, 2002).

Surprisingly, acquisitions have the opposite effect on Tobin's $q$. We find that acquisitions made by EGC firms have a positive impact on Tobin's $q$. This positive reaction is rather counterintuitive as one would expect that acquisitions made under incomplete disclosure would prompt investors to penalize the stock price. However, we hypothesize that a lower disclosure level gives managers more flexibility to overstate the goodwill portion of the purchase price of an acquisition. Moreover, as noted by Shalev (2009), an excess amount allocated to goodwill incentivizes managers to withhold relevant information in order to minimize scrutiny from investors. ${ }^{41}$ Together these factors allow managers of the acquiring firm to project better longterm growth prospects from the acquisition and higher future earnings when the disclosure intensity required by law is low. ${ }^{42}$

The interactions between $E x E G C$ and the acquisition proxies in models 4-6 confirm these

\footnotetext{
${ }^{41}$ Relatedly, Shalev (2009) finds that acquirers make fewer disclosures when they allocate an abnormal portion of the purchase price to goodwill (defined as purchase price minus the net fair value of the acquired assets). Low disclosure allows acquirers to project higher post-acquisition earnings per share by simply allocating a greater portion of the purchase price to goodwill and by lowering the portion allocated to net assets (either by understating assets or overstating liabilities). This allows them to get away with overpaying for acquiring a target company that could eventually be detrimental to shareholder interests.

${ }^{42}$ In fact, we show in online Appendix E that managers of EGC firms have more discretion over managing reported earnings while they are exempt from mandatory disclosure.
} 
interpretations. ${ }^{43}$ Coefficients of the interactions are negative and significant up to the $1 \%$ level. Thus, another reason why EGCs pursue fewer acquisitions when under mandatory disclosure is because the market is more capable of scrutinizing such transactions under this setting. Our evidence suggests that acquisitions by ExEGCs are deemed by the market to be value-reducing in the long run, resulting in a marginally lower Tobin's $q$.

\subsection{Managerial Effort}

The findings thus far have shown that EGCs invest less and focus on better utilization of assets upon losing their exemptions. A natural question arises whether these changes create operational efficiencies due to a shift in managerial attention towards improving the quality of goods and services, lowering costs, and reducing financial constraints. The evidence presented in Table 8 is consistent with these predictions. Holding everything else constant, ExEGCs generate $31 \%$ more sales per dollar of invested assets (model 2) and up to $29 \%$ higher return on assets (model 4) than EGC firms. There is also a $41 \%$ drop in the probability of having net income below zero upon the switch to full disclosure. Lastly, firms are financially less constrained under the mandatory regime (models 7-8). Overall, these results suggest that mandatory disclosure compels managers of EGC firms to redirect efforts from investing to improving profitability and operational efficiency.

\section{--- Table 8 ---}

\section{Conclusion}

This paper explores how mandatory disclosure affects the growth opportunities of firms, taking into account their fundraising and investment behaviour. For this purpose, we focus on firms entering public markets as EGCs under the JOBS Act, which exempts them from disclosure and compliance obligations for a period of up to five years post-IPO. For our analysis, we exploit the fact that an EGC will lose its exemptions and become fully disclosing if its float exceeds $\$ 700$ million at any time during the five-year period. We investigate how

\footnotetext{
${ }^{43}$ Note that since our empirical analysis is at the firm-year level, we do not provide a more direct test of whether EGC managers allocate a greater portion of the purchase price of their acquisitions to goodwill when the firm is exempt from mandatory disclosure under the provisions of the JOBS Act. Such an analysis can only be done at the individual deal level, and is left as an open question for future research.
} 
the financing and investment decisions made by firms during their status as EGCs impact their growth opportunities (proxied by Tobin's $q$ ) compared to similar decisions made by these firms after they lose exemptions due to the $\$ 700$ million rule and become ExEGCs.

We find that even though firms invest more in physical assets, innovation, and acquisitions while they are EGCs, they experience a considerable decline in Tobin's $q$ as long as they remain exempt from mandatory disclosure. There is substantial improvement in both investment and operational efficiency once these firms lose exemptions and become ExEGCs. This increased efficiency, combined with improved transparency under stricter disclosure, results in better recognition of growth opportunities by outside investors and a corresponding improvement in Tobin's $q$. Our findings highlight that by allowing firms to choose their optimal level of disclosure, the JOBS Act is incentivizing inefficient investments that do not contribute much value to the firm. Supplementary evidence presented in appendices D and E shows that EGCs experience an increase in audit fees and weaker control over earnings after they cease to remain exempt. The increased compliance costs under mandatory disclosure explain, at least in part, why many EGCs attempt to stay below the $\$ 700$ million threshold by manipulating their float.

Our study informs the longstanding policy debate over the growing regulatory burden that has made it difficult for promising high-growth companies to access capital. The JOBS Act represents the last major deregulation of US capital markets. It seeks to stem the decline in IPOs by unwinding the "regulatory cascade" following the tech bubble and accounting scandals of the early 2000s that imposed high disclosure and compliance costs on firms going public. To the best of our knowledge, ours is the first study to investigate the Act's implications on the valuation and growth opportunities of firms entering public markets under its provisions.

The JOBS Act continues to receive strong political support and press coverage. Recently, the US Congress passed the "JOBS Act 3.0" that extends several Title I provisions including the relaxed disclosure requirements. In light of these developments, our findings raise concerns over such initiatives and question whether lawmakers are pursuing the right policy to spur economic growth by easing the regulatory burden on firms. More research is needed to identify the optimal ways in which disclosure regulation governing US capital markets could be streamlined to facilitate better value creation by firms. 


\section{$\underline{\text { References }}$}

Alsabah, K., and Moon, S. K., 2020, IPO Regulation and Initial Capital Structure: Evidence from the JOBS Act, Available at SSRN.

Asker, J., Farre-Mensa, J., and Ljungqvist, A., 2015, Corporate investment and stock market listing: A puzzle?, The Review of Financial Studies 28, 342-390.

Aslan, H., and Kumar, P., 2011, Lemons or cherries? Growth opportunities and market temptations in going public and private, Journal of Financial and Quantitative Analysis 489526.

Baker, M., and Wurgler, J., 2002, Market timing and capital structure, The Journal of Finance 57, 1-1.

Balogh, A., Creedy, U., and Wright, D., 2021, Time to acquire: Regulatory burden and M\&A activity, Available at SSRN: https://ssrn.com/abstract $=3523630$

Barth, M. E., Landsman, W. R., and Taylor, D. J., 2017, The JOBS Act and information uncertainty in IPO firms, The Accounting Review 92, 25-47.

Bernstein, S., 2015, Does going public affect innovation?, The Journal of Finance 70, 13651403.

Brau, J. C., and Fawcett, S. E., 2006, Initial public offerings: An analysis of theory and practice, The Journal of Finance 61, 399-436.

Brau, J. C., Francis, B., and Kohers, N., 2003, The Choice of IPO versus Takeover: Empirical Evidence*, The Journal of Business 76, 583-612.

Brown, J. R., Fazzari, S. M., and Petersen, B. C., 2009, Financing innovation and growth: Cash flow, external equity, and the 1990s R\&D boom, The Journal of Finance 64, 151-185.

Bushee, B. J., and Leuz, C., 2005, Economic consequences of SEC disclosure regulation: evidence from the OTC bulletin board, Journal of accounting and economics 39, 233-264.

Cabezon, F., 2020, The Effect of Mandatory Information Disclosure on Financial Constraints, Available at SSRN. 
Calonico, S., Cattaneo, M., and Farrell, M., 2018, On the effect of bias estimation on coverage accuracy in nonparametric inference, Journal of the American Statistical Association 113, 767 779 .

Calonico, S., Cattaneo, M., Farrell, M., and Titiunik, R., 2017, rdrobust: Software for regression-discontinuity designs, The Stata Journal 17, 372-404.

Cattaneo, M. D., Jansson, M., and Ma, X., 2019, Simple local polynomial density estimators, Journal of the American Statistical Association 1-7.

Chaplinsky, S., Hanley, K. W., and Moon, S. K., 2017, The JOBS Act and the costs of going public, Journal of Accounting Research 55, 795-836.

Cho, Y. J., 2015, Segment disclosure transparency and internal capital market efficiency: Evidence from SFAS No. 131, Journal of Accounting Research 53, 669-723.

Choe, H., Masulis, R. W., and Nanda, V., 1993, Common stock offerings across the business cycle: Theory and evidence, Journal of Empirical finance 1, 3-31.

Coates, J. C., and Srinivasan, S., 2014, SOX after ten years: A multidisciplinary review, Accounting Horizons 28, 627-671.

Corwin, S. A., 2003, The determinants of underpricing for seasoned equity offers, The Journal of Finance 58, 2249-2279.

Dambra, M., Field, L. C., and Gustafson, M. T., 2015, The JOBS Act and IPO volume: Evidence that disclosure costs affect the IPO decision, Journal of Financial Economics 116, 121-143.

Dambra, M., and Gustafson, M., 2021, Do the Burdens to Being Public Affect the Investment and Innovation of Newly Public Firms?, Management Science 67, 594-616.

DeAngelo, H., DeAngelo, L., and Stulz, R. M., 2010, Seasoned equity offerings, market timing, and the corporate lifecycle, Journal of Financial Economics 95, 275-295.

Doidge, C., Karolyi, G. A., and Stulz, R. M., 2013, The US left behind? Financial globalization and the rise of IPOs outside the US, Journal of Financial Economics 110, 546-573.

Doidge, C., Karolyi, G. A., and Stulz, R. M., 2017, The US listing gap, Journal of Financial Economics 123, 464-487. 
Fishman, M. J., 1989, Preemptive bidding and the role of the medium of exchange in acquisitions, The Journal of Finance 44, 41-57.

Francis, J. R., Huang, S., Khurana, I. K., and Pereira, R., 2009, Does corporate transparency contribute to efficient resource allocation?, Journal of Accounting Research 47, 943-989.

Frank, M. Z., and Shen, T., 2016, Investment and the weighted average cost of capital, Journal of Financial Economics 119, 300-315.

Gao, H., and Zhang, J., 2018, SOX Section 404 and corporate innovation, Journal of Financial and Quantitative Analysis (JFQA), Forthcoming.

Gao, X., Ritter, J. R., and Zhu, Z., 2013, Where have all the IPOs gone?, Journal of Financial and Quantitative Analysis 48, 1663-1692.

Gilson, R. J., and Black, B. S., 1995. The law and finance of corporate acquisitions (Foundation Press Westbury, NY).

Greenstone, M., Oyer, P., and Vissing-Jorgensen, A., 2006, Mandated disclosure, stock returns, and the 1964 Securities Acts amendments, The Quarterly Journal of Economics 121, 399-460.

Hanka, G., 1998, Debt and the terms of employment, Journal of Financial Economics 48, 245 282.

Ho, Y. K., Tjahjapranata, M., and Yap, C. M., 2006, Size, leverage, concentration, and R\&D investment in generating growth opportunities, The Journal of Business 79, 851-876.

Hope, O. k., and Thomas, W. B., 2008, Managerial empire building and firm disclosure, Journal of Accounting Research 46, 591-626.

Iliev, P., 2010, The effect of SOX Section 404: Costs, earnings quality, and stock prices, The Journal of Finance 65, 1163-1196.

IPO Task Force, 2011, Rebuilding the IPO on-ramp: Putting emerging companies and the job market back on the road to growth, Report Presented to The US Department of the Treasury.

Jensen, M. C., and Meckling, W. H., 1976, Theory of the firm: Managerial behavior, agency costs and ownership structure, Journal of Financial Economics 3, 305-360.

Jones, J. J., 1991, Earnings management during import relief investigations, Journal of Accounting Research 29, 193-228. 
Kang, Q., Liu, Q., and Qi, R., 2010, The Sarbanes-Oxley act and corporate investment: A structural assessment, Journal of Financial Economics 96, 291-305.

Kaplan, S. N., and Zingales, L., 1997, Do investment-cash flow sensitivities provide useful measures of financing constraints?, The Quarterly Journal of Economics 112, 169-215.

Kim, W., and Weisbach, M. S., 2008, Motivations for public equity offers: An international perspective, Journal of Financial Economics 87, 281-307.

Knopf, J. D., Nam, J., and Thornton Jr, J. H., 2002, The volatility and price sensitivities of managerial stock option portfolios and corporate hedging, The Journal of Finance 57, 801-813.

Kothari, S., Laguerre, T. E., and Leone, A. J., 2002, Capitalization versus expensing: Evidence on the uncertainty of future earnings from capital expenditures versus R\&D outlays, Review of Accounting Studies 7, 355-382.

Kraft, A. G., Vashishtha, R., and Venkatachalam, M., 2018, Frequent financial reporting and managerial myopia, The Accounting Review 93, 249-275.

Lamont, O., Polk, C., and Saaá-Requejo, J., 2001, Financial constraints and stock returns, The Review of Financial Studies 14, 529-554.

Lang, M., Lins, K. V., and Maffett, M., 2012, Transparency, liquidity, and valuation: International evidence on when transparency matters most, Journal of Accounting Research 50, 729-774.

Leary, M. T., and Roberts, M. R., 2005, Do firms rebalance their capital structures?, The Journal of Finance 60, 2575-2619.

Lee, D. S., and Lemieux, T., 2010, Regression discontinuity designs in economics, Journal of Economic Literature 48, 281-355.

Leuz, C., and Wysocki, P. D., 2016, The economics of disclosure and financial reporting regulation: Evidence and suggestions for future research, Journal of accounting research 54, 525-622.

Loderer, C., Stulz, R., and Waelchli, U., 2017, Firm rigidities and the decline in growth opportunities, Management Science 63, 3000-3020.

Lowry, M., 2003, Why does IPO volume fluctuate so much?, Journal of Financial economics $67,3-40$. 
Mahoney, P. G., 1997, The exchange as regulator, Virginia Law Review 1453-1500.

Palmiter, A. R., 1999, Toward disclosure choice in securities offerings, Colum. Bus. L. Rev. 1.

Pástor, L., and Veronesi, P., 2003, Stock valuation and learning about profitability, The Journal of Finance 58, 1749-1789.

Purnanandam, A. K., and Swaminathan, B., 2004, Are IPOs really underpriced?, The Review of Financial Studies 17, 811-848.

Ritter, J. R., and Welch, I., 2002, A review of IPO activity, pricing, and allocations, The Journal of Finance 57, 1795-1828.

Romano, R., 1998, Empowering investors: a market approach to securities regulation, The Yale Law Journal 107, 2359-2430.

Shalev, R., 2009, The information content of business combination disclosure level, The Accounting Review 84, 239-270.

Sherman, A. E., and Titman, S., 2002, Building the IPO order book: underpricing and participation limits with costly information, Journal of Financial Economics 65, 3-29.

Shleifer, A., and Vishny, R. W., 2003, Stock market driven acquisitions, Journal of Financial Economics 70, 295-311.

Teach, E., 2014, How the JOBS Act helped five CFOs take companies public, On the IPO OnRamp (CFO.com).

Teoh, S. H., Welch, I., and Wong, T. J., 1998, Earnings management and the long-run market performance of initial public offerings, The Journal of Finance 53, 1935-1974. 
Figure 1. Do EGCs Manipulate their Float?

Panel (a) visualizes tests for density discontinuity in the float of US companies on the last day of their second fiscal quarter. Firms in the sample had less than $\$ 1$ billion revenue on the day of their IPO. The running variable float is the market value of common equity held by public investors on the last day of the preceding second fiscal quarter. The left-hand plot represents the treatment period between April 6, 2012 and April 30, 2019 in which firms went public as EGCs. The right-hand plot represents the placebo period prior to the JOBS Act (January 1, 2000-April 4, 2012) when IPO firms did not qualify for EGC status. See Section 3.1 for a description of the sample construction. Observations to the right of the vertical cutoff (float $\geq$ $\$ 700$ million) imply that the firm becomes a "Large Accelerated Filer" subject to mandatory disclosure requirements under the Securities Act. The manipulation test statistic at the top right corner of each plot is based on local polynomial density estimation from Cattaneo, Jansson and Ma (2019). The $p$-value of the test statistic is shown in parantheses. A statistically significant discontinuity implies possible manipulation of float near the cutoff. Panel (b) visualizes coefficients from probit models that estimate the likelihood that an EGC firm buys back shares to stay below the LAF threshold. The dependent variable in the left-hand plot is a dummy equal to one if an EGC initiates a share buyback program during the six months preceding the last day of the second fiscal quarter. The dependent variable in the right-hand plot is a dummy equal to one if an EGC initiates a share buyback program during the six months following the last day of the second fiscal quarter. The main variable of interest (x-axis) is the firm's float (i) exactly six months before the end of most recent second fiscal quarter (left plot), (ii) on the last day of most recent second fiscal quarter (right plot). In each plot, the x-axis is split into a categorical variable comprising different sub-ranges of the float. Separate regressions are run for each additional year the firm has been a public company (Listing Age). Each regression controls for firm size, financial characteristics, stock market conditions, and industry fixed effects. Standard errors are clustered by firm. Regions shaded in blue denote the float range at which an EGC will likely exceed the LAF threshold and lose its exemptions. Vertical bars are $90 \%$ confidence intervals.

a) Density tests

EGC firms (at IPO)

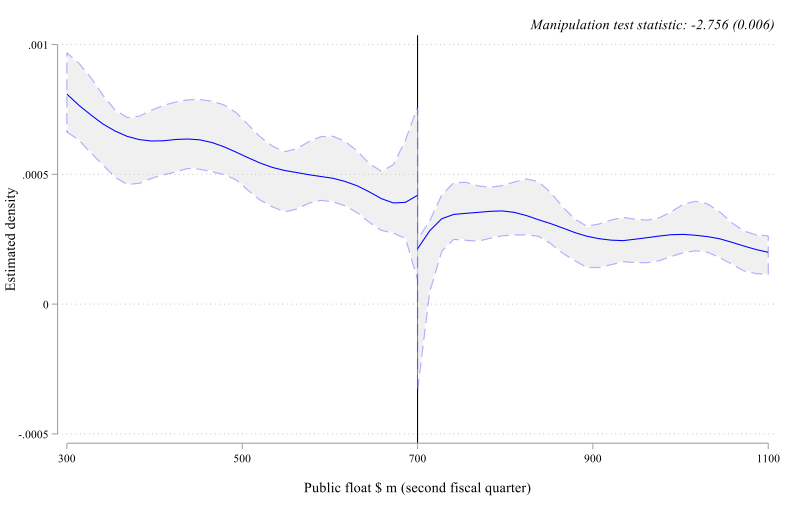

NonEGC firms (placebo)

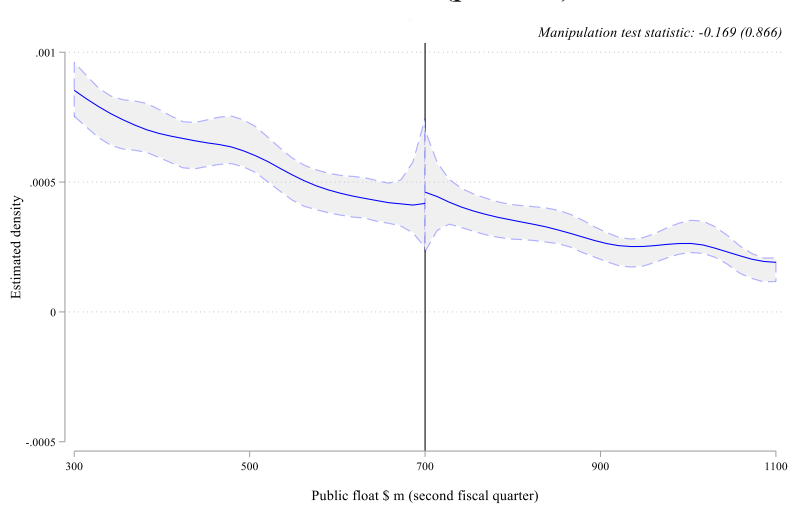

b) Share buybacks by firms going public under EGC treatment

0-6 months before end of $2^{\text {nd }}$ fiscal quarter

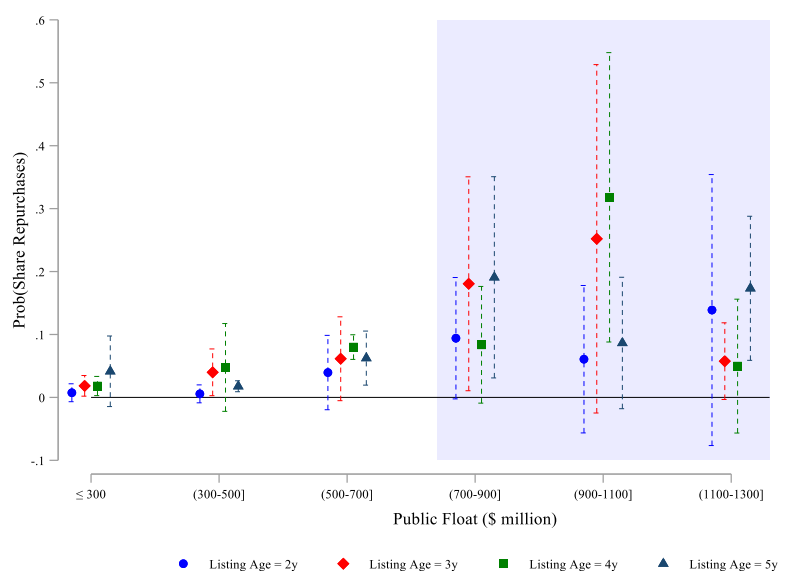

0-6 months after end of $2^{\text {nd }}$ fiscal quarter

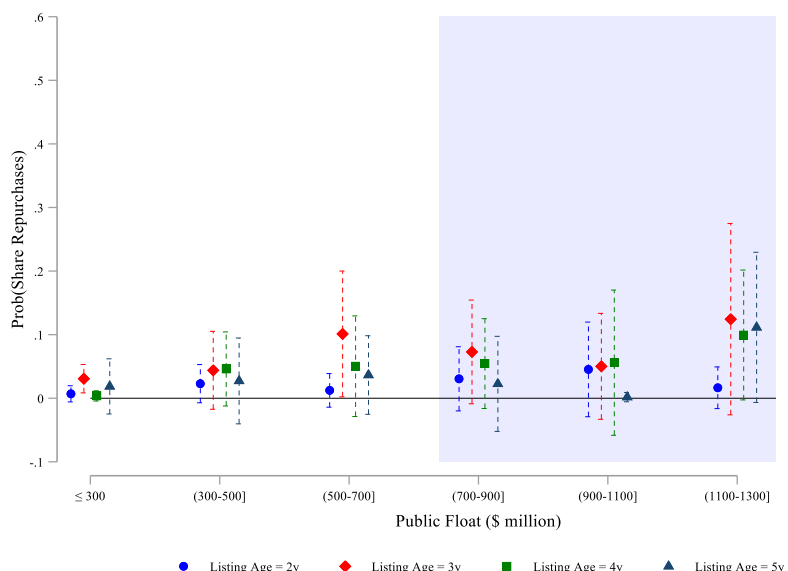


Figure 2. Duration of EGC Status

Panel (a) is a distributional plot of the duration for which EGC firms remain exempt following their IPO. Duration is the period (in quarters) between the IPO date and the date on which the firm loses its EGC exemptions. The plot covers 248 EGC firms that ceased to remain exempt either: (i) upon becoming a "Large Accelerated Filer", or, (ii) upon completing maximum exemption period of five years after the IPO. The sample covers US firms that went public between the period April 6, 2012 and April 30, 2019. See Section 3.1 for a description of the sample construction. Panel (b) presents violin plots of EGC duration for each cohort of US firms grouped by IPO year. Red dots indicate median EGC duration. Panel (c) shows box plots of EGC duration among high- $q$ (Tobin's $q>1$ ) and low- $q$ (Tobin's $q \leq 1$ ) firms that went public as EGCs.

a) All EGC firms

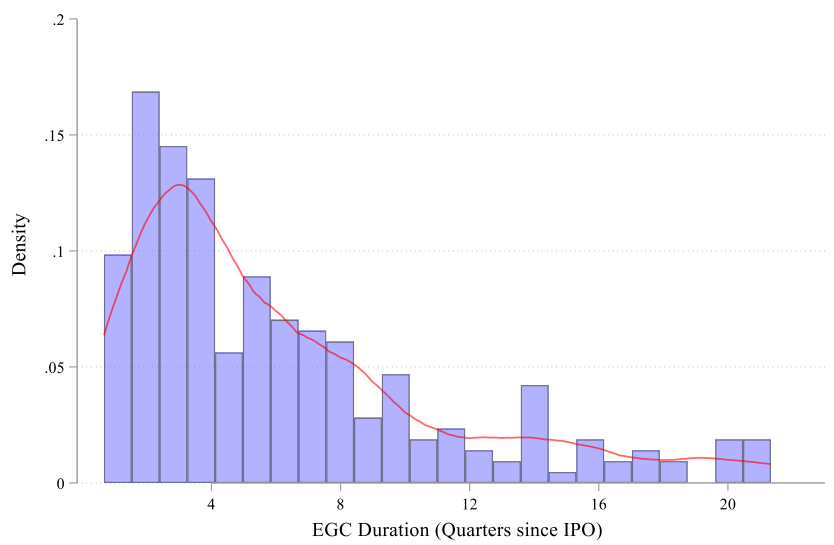

b) By IPO year

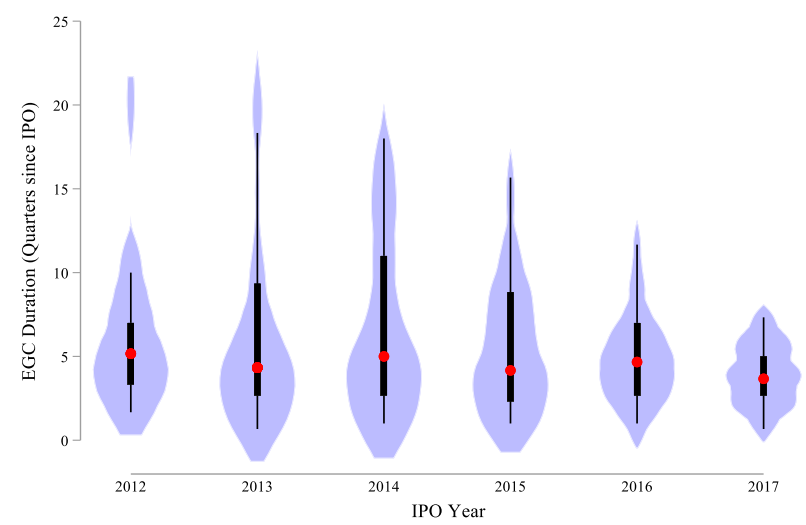

c) High- $q$ versus low- $q$ EGC firms (at IPO)

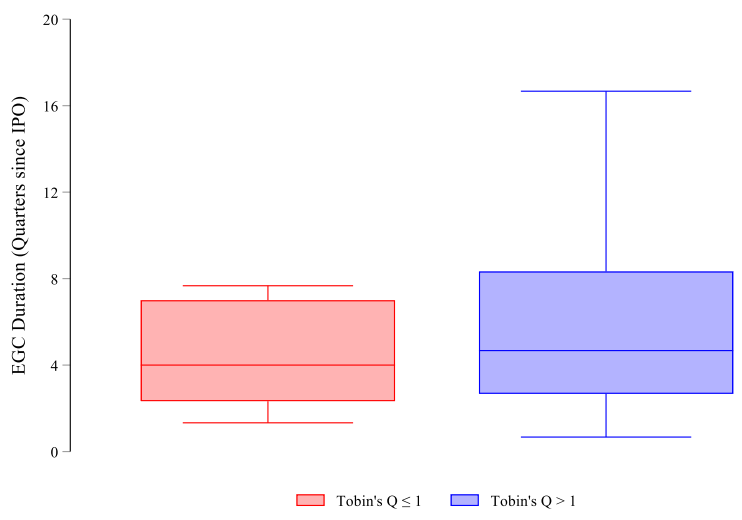


Figure 3. Fundraising Sensitivity to LAF Regulation

Panel (a) shows local polynomial regression plots of equity and debt issuance by US firms that went public as an EGC against their float. Equity issuance (New Equity) is measured as the dollar value of common stock issued by the firm via seasoned public offers (SPOs) during a fiscal year. Data on SPOs is collected from Capital IQ, and includes only offers that involve a sale of new primary stock independent of existing shareholders. Net Equity Issuance is the difference between New Equity and Purchased Equity in a given fiscal year. Debt issuance (New Debt) by the firm in a given year is the total annual long-term debt issued, and covers bonds, notes, lease obligations, debt reclassifications, and acquisition loans. This variable is computed from Compustat data item DLTIS. Panel (b) presents local polynomial regression plots of equity and debt issuance among firms that went public before the JOBS Act (January 1, 2000-April 4, 2012) and therefore do not quality for EGC treatment during their IPO (NonEGC firms). See Section 3.1 for a description of the sample construction. See Table A1 for a description of these variables.

a) EGC firms (at IPO)

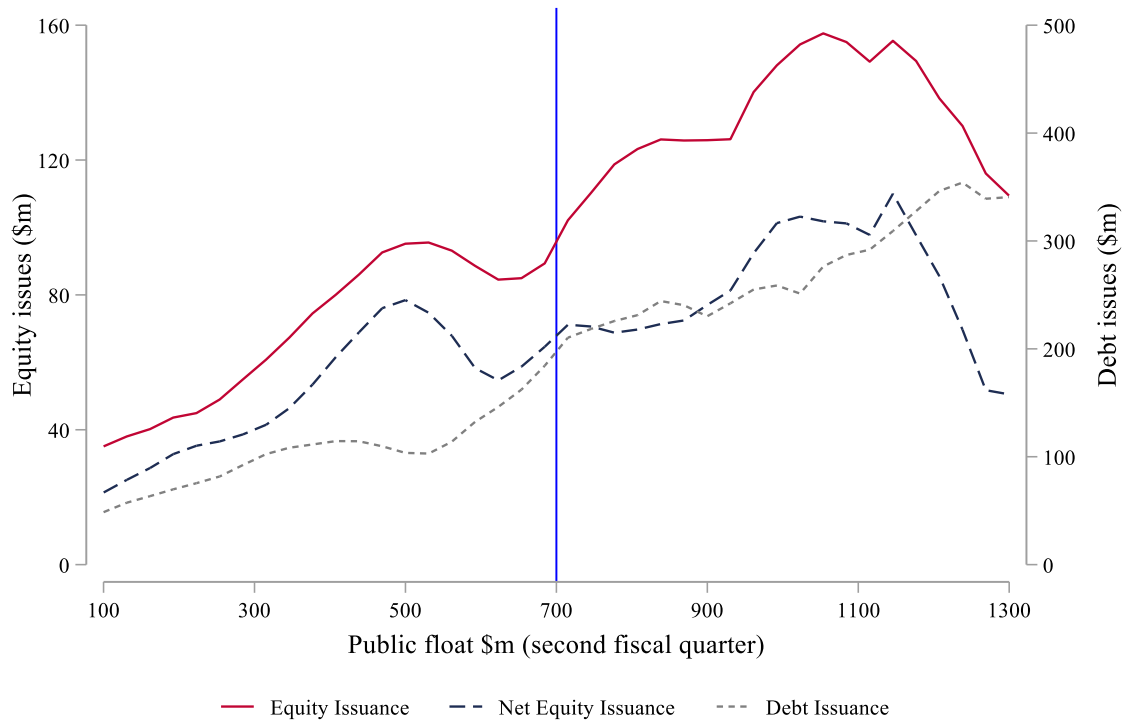

b) NonEGC firms

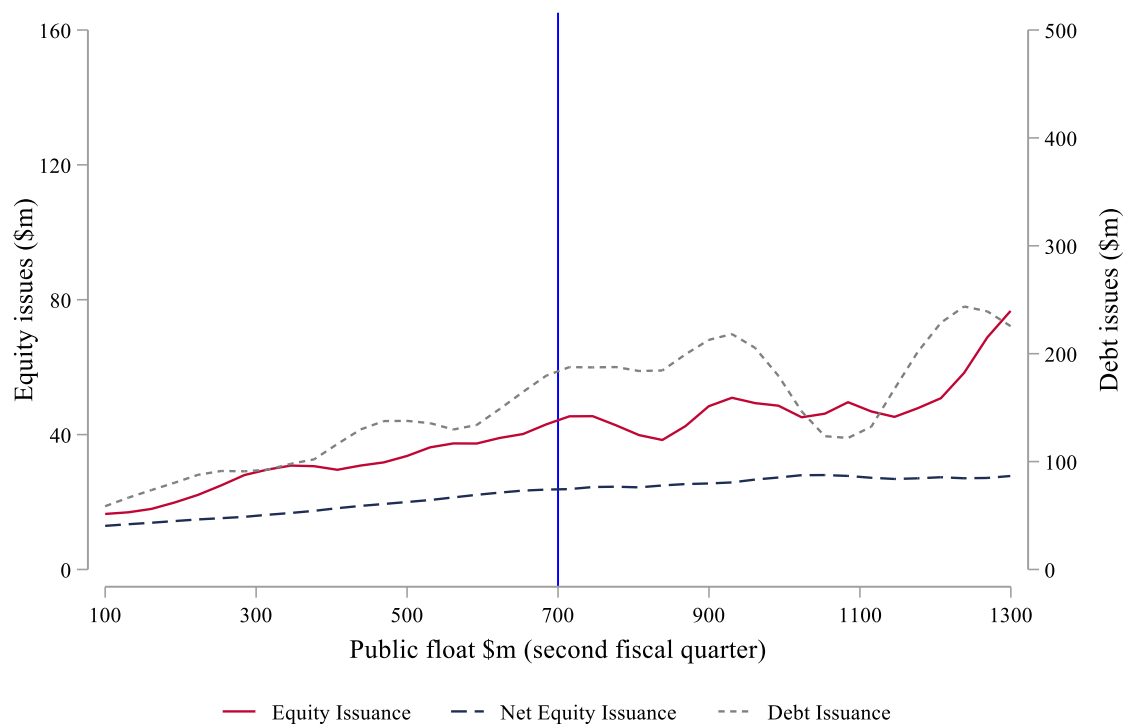


Figure 4. EGC Status and Equity Issuance

Each plot relates a firm's equity issuance per year to its float. The sample comprises firms that went public as an "Emerging Growth Company" between April 6, 2012 and April 30, 2019. See Section 3.1 for a description of the sample construction. In panel (a), the left plot compares equity issuance among EGC and ExEGC firms. EGC refers to the firms that have float below $\$ 700$ million and thus remain exempt from mandatory disclosure under Title I of the JOBS Act. ExEGC is a refers to firms that have a float above $\$ 700$ million, and are thus subject to mandatory disclosure under the "Large Accelerated Filer" (LAF) regulation. The plot on the right shows equity issuance among a placebo sample of NonEGC firms that went public before the JOBS Act (January 1, 2000-April 4, 2012) and thus did not quality for EGC treatment during their IPO. Local linear regressions are fit on either side of the LAF cutoff in each plot, as indicated by the blue lines. Panel (b) shows comparative estimates of equity issuance scaled by lagged assets as a function of float. See Table A1 for a description of these variables.

a) Equity Issuance (\$m)
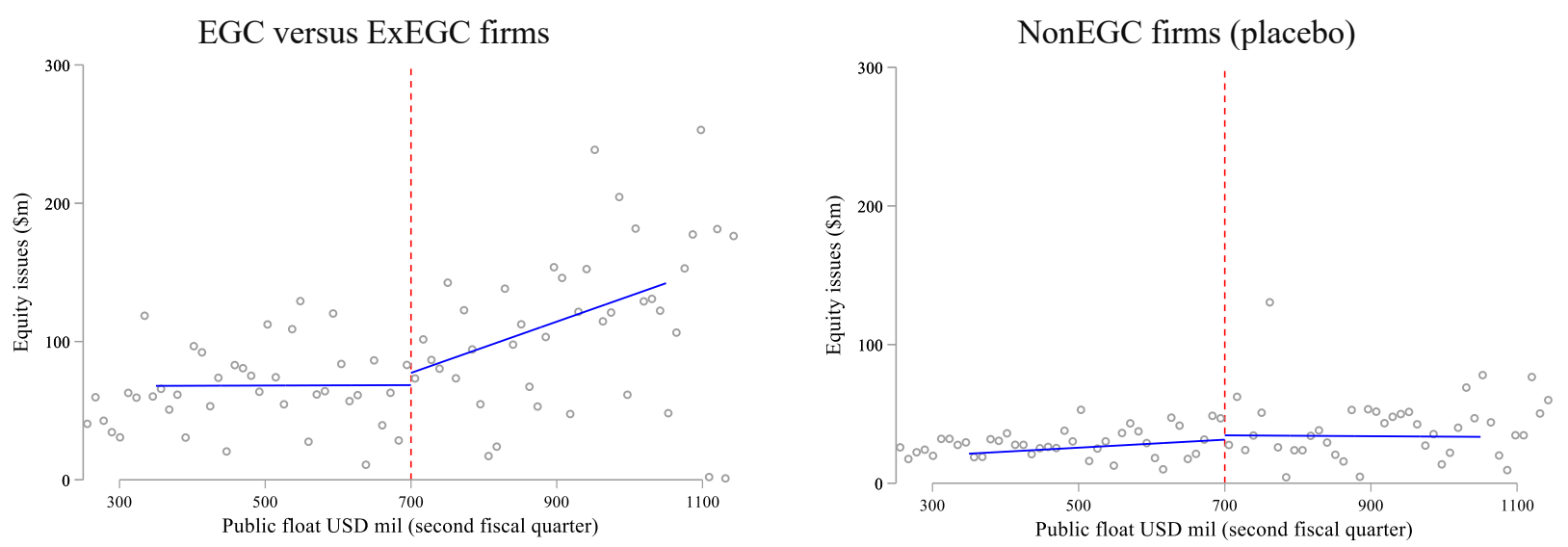

b) Equity issuance by lagged assets
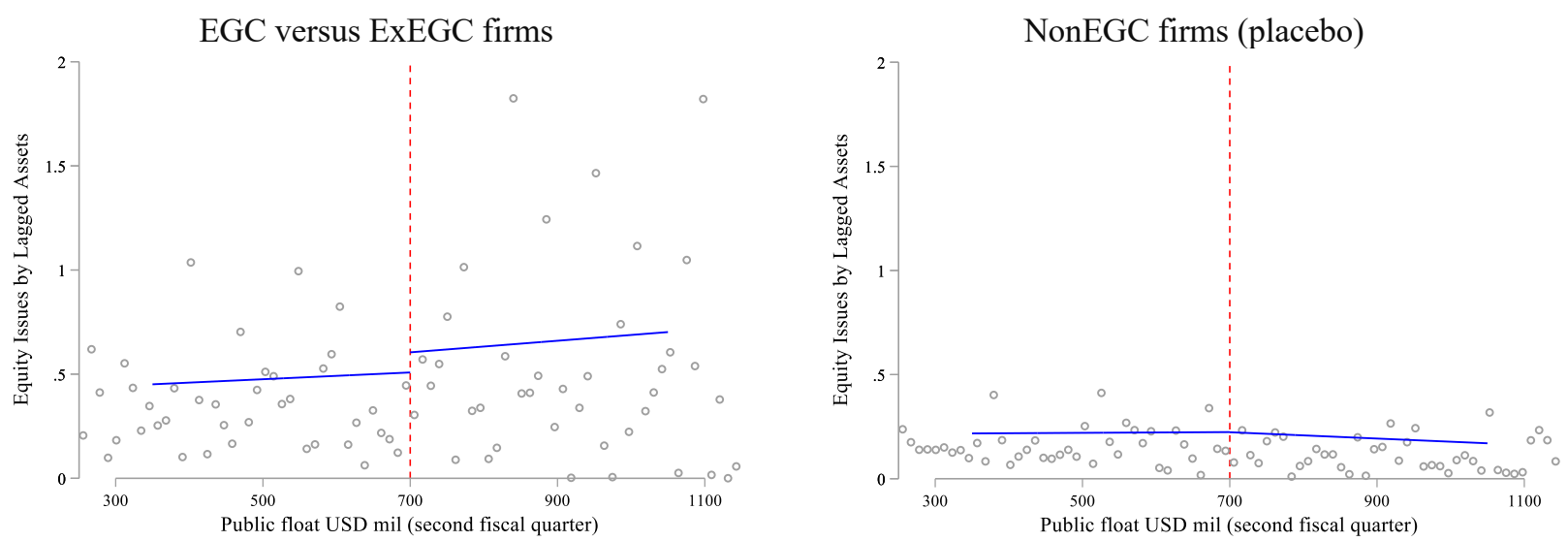
Figure 5. EGC Status and Debt Issuance

Each plot relates a firm's debt issuance per year to its float. The sample comprises firms that went public as an "Emerging Growth Company" between April 6, 2012 and April 30, 2019. See Section 3.1 for a description of the sample construction. In panel (a), the left plot compares debt issuance among EGC and ExEGC firms. EGC refers to the firms that have float below $\$ 700$ million and thus remain exempt from mandatory disclosure under Title I of the JOBS Act. ExEGC refers to firms that have a float above $\$ 700$ million, and are thus subject to mandatory disclosure under the "Large Accelerated Filer" (LAF) regulation. The right-hand plot shows debt issuance among a placebo sample of NonEGC firms that went public before the JOBS Act (January 1, 2000-April 4, 2012) and thus did not quality for EGC treatment during their IPO. Local linear regressions are fit on either side of the LAF cutoff in each plot, as indicated by the blue lines. Panel (b) shows comparative estimates of debt issuance scaled by lagged assets as a function of float. See Table A1 for a description of these variables.

a) Debt Issuance $(\$ m)$
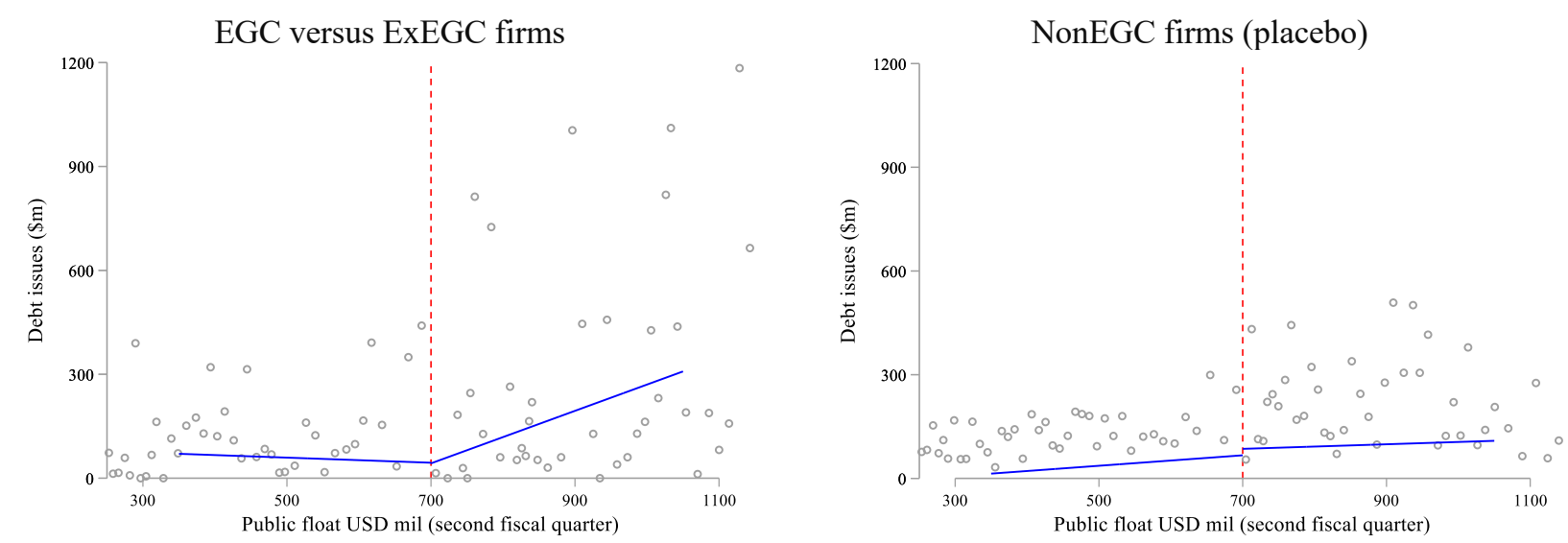

b) Debt issuance by lagged assets
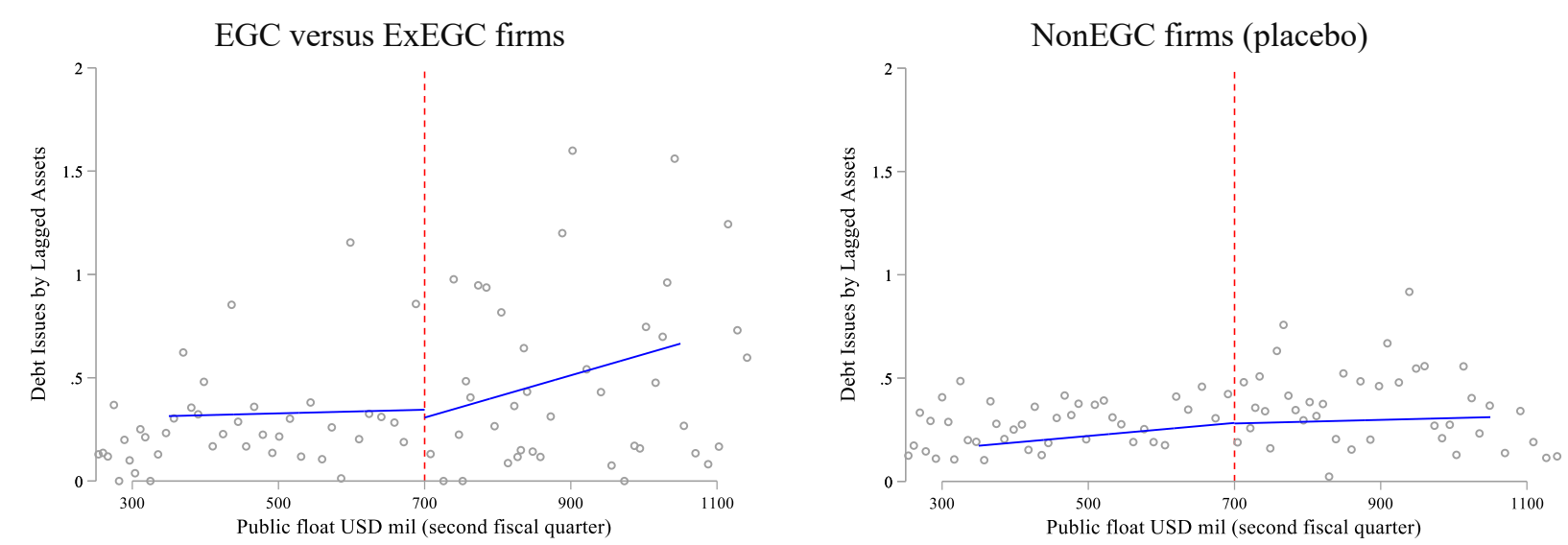
Figure 6. Fraction of Firms Raising Equity and Debt by Listing Age

Panel (a) presents the fraction of firms raising equity and debt during the first six years after their IPO. The sample comprises all firms that went public as an "Emerging Growth Company" (EGC) between April 6, 2012 and April 30, 2019. See Section 3.1 for a description of the sample construction. EGC firms are exempt from mandatory disclosure under Title I of the JOBS Act for a maximum period of five years, unless their float exceeds $\$ 700$ million at the end of a given second fiscal quarter and qualifies them as a "Large Accelerated Filer" (LAF) subject to full disclosure. Panel (b) presents a visual implementation of the regression estimates for debt and equity issuance reported in panel (b) of Table 3. Each figure displays coefficients of individual year dummies denoting the number of years a firm has been public (blue line), and their interactions with an ExEGC dummy (red line). ExEGC is equal to one for EGC firms having a float above $\$ 700$ million that are subject to mandatory disclosure under the LAF regulation, and zero for EGC firms whose float is below the threshold. Vertical bands represent $90 \%$ confidence intervals. For this analysis, we restrict the sample to firms whose float is within a bandwidth $h=\$ 350$ million on either side of the LAF cutoff. See Table A1 for a description of these variables.

a) EGC firms (at IPO)
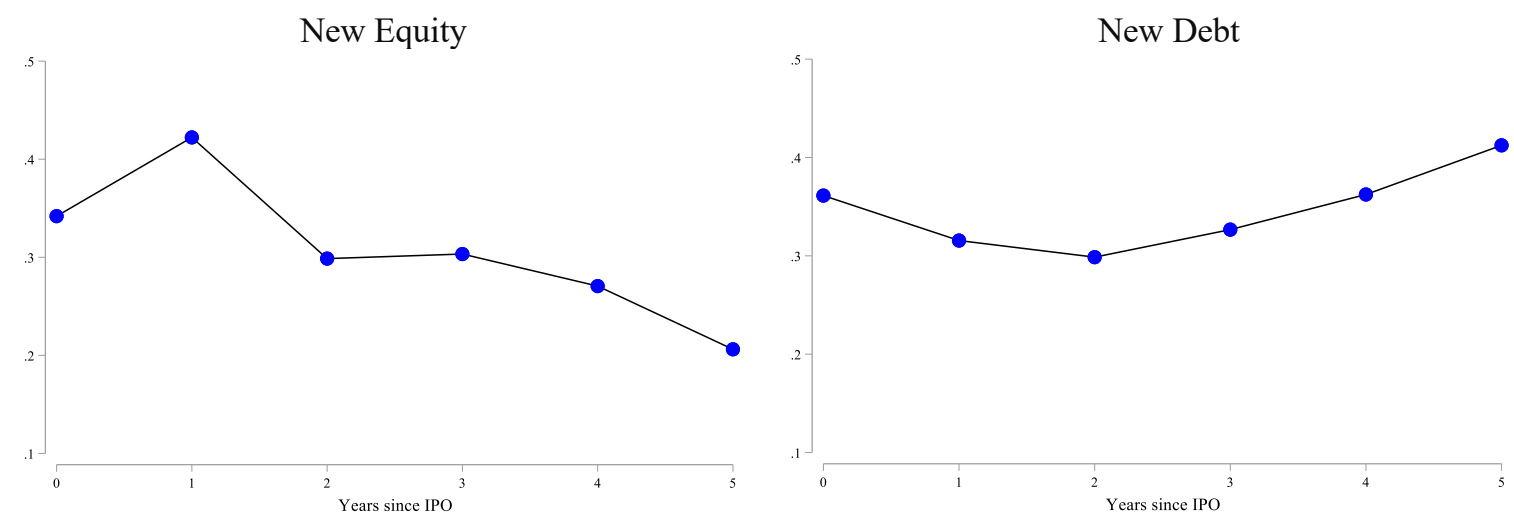

b) EGC versus ExEGC firms ( $h=\$ 350$ million $)$
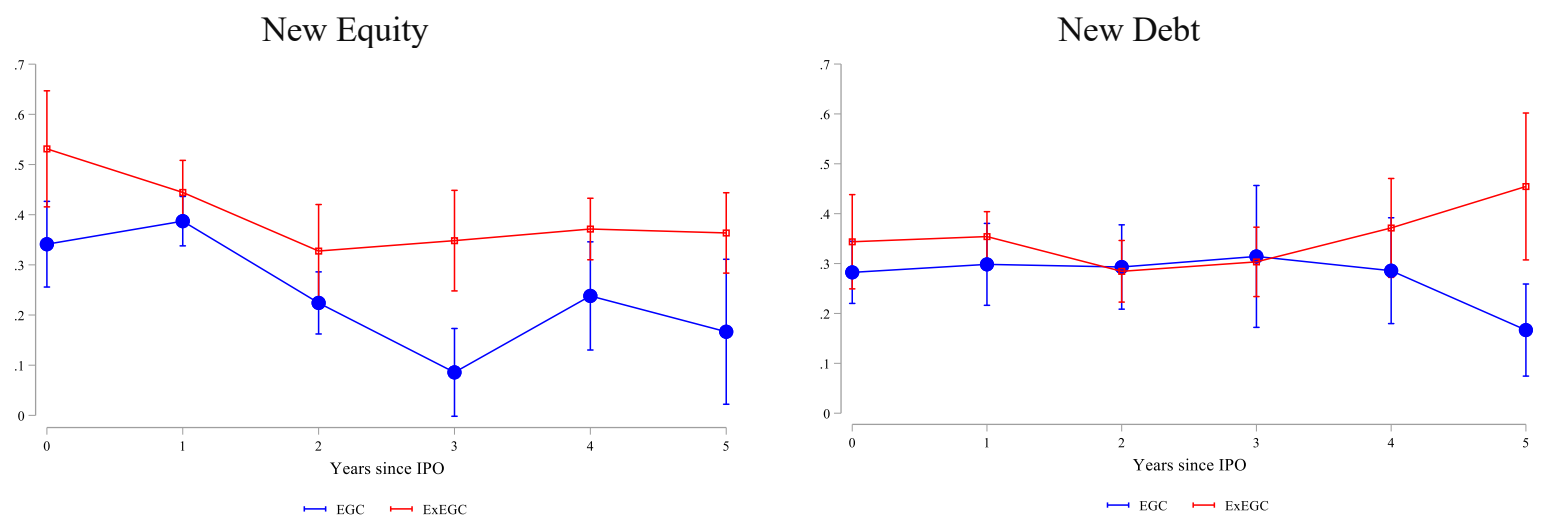


\section{Figure 7. EGC Status and Growth Opportunities}

The sample used for the plots comprises firms that went public as an "Emerging Growth Company" (EGC) between April 6, 2012 and April 30, 2019, and have a float between \$350 million and \$1,050 million in any given year. See Section 3.1 for a description of the sample construction. The left-hand figure in panel (a) shows the non-parametric relation between growth opportunities, proxied by Tobin's q, and ExEGC. The variable ExEGC is a dummy equal to one for firms having a float above $\$ 700$ million that are subject to mandatory disclosure under the "Large Accelerated Filer" (LAF) regulation, and zero for firms whose float is below the threshold. The right-hand figure in panel (a) plots the residuals from an OLS regression of Tobin's $q$ on the ExEGC dummy, firm-level controls, and industry-year fixed effects. Panel (b) plots the fraction of firms whose Tobin's $q$ exceeds $q_{0}$ (Tobin's $q$ in the IPO year) as a function of Listing Age and EGC status (ExEGC). Listing Age is the number of years since the firm went public. To estimate these fractions, we follow Loderer, Stulz and Waelchli (2017) and regress Tobin's $q$ on firm size as well as industry and year fixed effects to estimate the residuals $q$ 's. We then compute the fraction of firms whose residual $q$ exceeds their respective residual $q_{0}$. See Table A1 for a description of these variables.

a) Tobin's $q$ and listing age
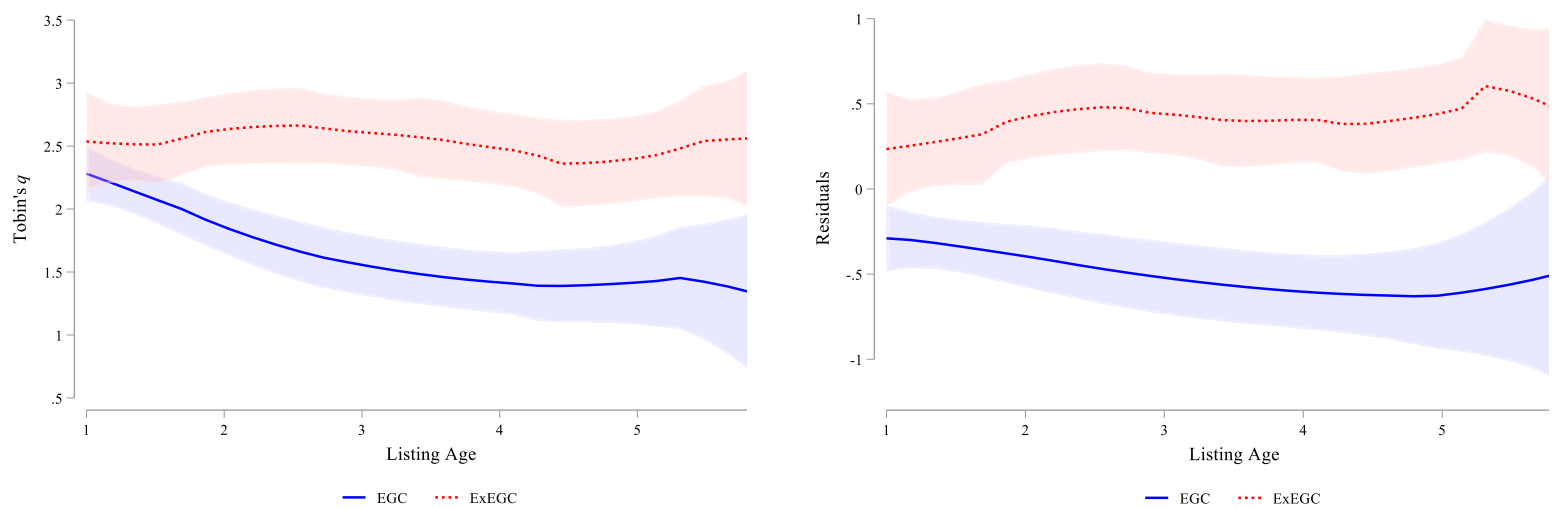

b) Likelihood of regenerating growth opportunities

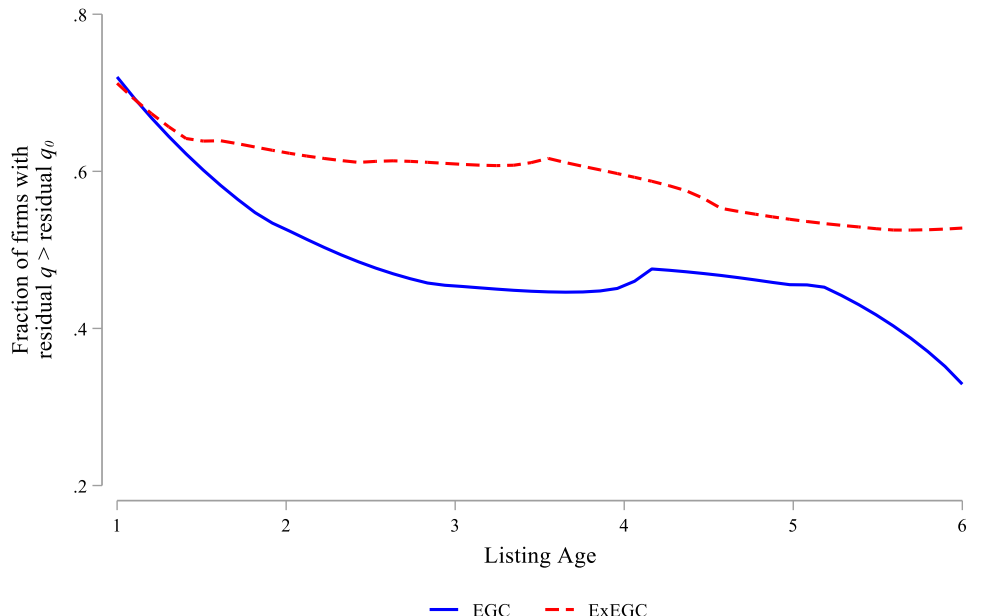


Table 1. Summary Statistics

The sample comprises US firms that went public as an "Emerging Growth Company" (EGC) between April 6, 2012 and April 30, 2019. See Section 3.1 for a description of the sample construction. Panel A reports summary statistics on firms that have a float below $\$ 700$ million and are exempt as EGCs from mandatory disclosure under Title I of the JOBS Act. Panel B reports summary statistics on firms that no longer qualify as EGCs on account of having a float above $\$ 700$ million that subjects them to mandatory disclosure under the "Large Accelerated Filer" (LAF) regulation. Wherever applicable, total assets (TA) in the denominator are lagged by one year with respect to the numerator. See Table A1 for a description of these variables. ***, **, and $*$ denote significance at the $1 \%, 5 \%$, and $10 \%$ level, respectively.

\begin{tabular}{|c|c|c|c|c|c|c|c|}
\hline & \multicolumn{3}{|c|}{ Panel A: EGC firms } & \multicolumn{3}{|c|}{ Panel B: ExEGC firms } & \multirow{2}{*}{$\begin{array}{c}\text { Difference in } \\
\text { means }\end{array}$} \\
\hline & Mean & SD & Median & Mean & SD & Median & \\
\hline Number of Fiscal Quarters as EGC & - & - & - & 8.47 & 4.86 & 8.00 & \\
\hline Float (second fiscal quarter) & 861.82 & 1138.98 & 440.51 & 803.05 & 1100.66 & 400.76 & -58.77 \\
\hline Incorporation Age (years) & 13.75 & 15.01 & 10.00 & 12.73 & 14.33 & 9.00 & -1.02 \\
\hline \multicolumn{8}{|l|}{ Firm Characteristics } \\
\hline Total Assets, TA (\$m) & 207.57 & 341.85 & 115.68 & 895.70 & 1442.47 & 390.56 & $688.13 * * *$ \\
\hline Sales/Revenue (\$m) & 236.59 & 396.51 & 87.50 & 415.05 & 600.82 & 195.67 & $178.47 * * *$ \\
\hline Net Income (\$m) & -23.53 & 93.34 & -18.86 & 10.46 & 109.91 & 5.64 & $33.99 * * *$ \\
\hline Employees & 2491.22 & 4452.96 & 791.00 & 3011.37 & 5729.68 & 1100.00 & 520.15 \\
\hline Debt/TA & 0.18 & 0.26 & 0.03 & 0.21 & 0.28 & 0.07 & $0.03 * * *$ \\
\hline Cash/TA & 0.33 & 0.30 & 0.24 & 0.27 & 0.27 & 0.18 & $-0.06 * * *$ \\
\hline Board Size & 12.87 & 4.33 & 12.00 & 13.57 & 5.20 & 13.00 & $0.71 * * *$ \\
\hline Board Independence & 0.95 & 0.13 & 1.00 & 0.96 & 0.11 & 1.00 & 0.01 \\
\hline \multicolumn{8}{|l|}{ New Fundraising } \\
\hline New Equity $(\$ m)$ & 23.55 & 55.06 & 0.00 & 69.02 & 165.61 & 0.00 & $45.48 * * *$ \\
\hline New Debt $(\$ m)$ & 51.31 & 183.69 & 0.00 & 278.36 & 646.16 & 0.00 & $227.05 * * *$ \\
\hline \multicolumn{8}{|c|}{ Growth Opportunities and Operational Efficiency } \\
\hline Tobin's Q & 1.42 & 0.86 & 1.25 & 1.66 & 1.11 & 1.35 & $0.24 * * *$ \\
\hline Sales/Assets & 0.59 & 0.70 & 0.38 & 0.84 & 0.76 & 0.67 & $0.26 * * *$ \\
\hline ROA & -0.21 & 0.45 & -0.07 & -0.01 & 0.34 & 0.08 & $0.20 * * *$ \\
\hline Negative NI & 0.66 & 0.47 & 1.00 & 0.43 & 0.50 & 0.00 & $-0.22 * * *$ \\
\hline \multicolumn{8}{|l|}{ Internal Investments } \\
\hline Capex $(\$ m)$ & 53.04 & 210.40 & 3.96 & 67.55 & 262.58 & 8.06 & $14.51 * *$ \\
\hline Capex/Sales & 0.08 & 0.18 & 0.01 & 0.09 & 0.19 & 0.03 & 0.01 \\
\hline PPE & 254.63 & 234.85 & 14.64 & 338.07 & 269.65 & 33.81 & $83.44 * * *$ \\
\hline PPE/Sales & 0.33 & 0.81 & 0.03 & 0.38 & 0.81 & 0.09 & $0.06^{* * *}$ \\
\hline $\mathrm{R} \& \mathrm{D}(\$ \mathrm{~m})$ & 25.15 & 70.43 & 2.98 & 20.19 & 66.38 & 0.00 & $-4.96 * * *$ \\
\hline $\mathrm{R} \& \mathrm{D} /$ Sales & 1.13 & 4.22 & 0 & 0.55 & 2.56 & 0.00 & $-0.58 * * *$ \\
\hline \multicolumn{8}{|l|}{ External Investments } \\
\hline Number of acquisitions & 1.05 & 0.22 & 1.00 & 1.07 & 0.26 & 1.00 & 0.02 \\
\hline Value of acquisitions (\$m) & 283.26 & 729.21 & 71.39 & 215.89 & 610.08 & 44.75 & -67.37 \\
\hline All cash acquisitions (D) & 0.73 & 0.45 & 1.00 & 0.79 & 0.41 & 1.00 & 0.06 \\
\hline Observations & & 867 & & & 1101 & & \\
\hline
\end{tabular}


Table 2. Impact of EGC Status Loss on Fundraising

Table presents regression discontinuity (RD) estimates where the dependent variables are various measures of issuance. The OLS estimates are based on equation (1); the IV estimates are based on equations (2.1) and (2.2). Models (1) - (4) display results for Log (New Equity) defined as the natural logarithm of one plus the dollar value of common stock issued by the firm via seasoned public offers (SPOs) during a fiscal year. Models (5) - (8) for New Equity scaled by lagged total assets (TA). Models (9) - (12) for Log (New Debt) defined as the natural logarithm of one plus the dollar value of total long-term debt issued during a fiscal year. Models (13) - (16) for New Debt scaled by lagged total assets (TA). The sample comprises firms that went public as an "Emerging Growth Company" (EGC) between April 6, 2012 and April 30, 2019. See Section 3.1 for a detailed description of the sample construction. ExEGC is a dummy equal to one for firms having a float above $\$ 700$ million at the end of second fiscal quarter that are subject to mandatory disclosure under the "Large Accelerated Filer" (LAF) regulation, and zero for firms whose float is below the threshold. To minimize the effect of confounding factors, the analysis is restricted to firms whose float is within a bandwidth $h=\$ 250$ million around the LAF cutoff. See Table A4 in the online appendix for additional robustness checks using larger bandwidths $h \in$ (\$300 million, \$350million). For the IV regressions, ExEGC is the predicted treatment based on the first-stage model (2.1) using the variable $P F 700$ as an instrument. $P F 700$ is equal to one if the firm's float six months prior to the second fiscal quarter exceeds $\$ 700$ million, and zero otherwise. In all regressions, industry and year fixed effects are included. Standard errors are clustered by firm, and are reported in parentheses. $* * *, * *$, and $*$ denote significance at the $1 \%$, $5 \%$, and $10 \%$ level, respectively. See Table A1 for a detailed description of the variables.

\begin{tabular}{|c|c|c|c|c|}
\hline & \multicolumn{4}{|c|}{$\log$ (New Equity) } \\
\hline & \multicolumn{2}{|c|}{ OLS } & \multicolumn{2}{|c|}{ IV } \\
\hline & (1) & (2) & (3) & (4) \\
\hline ExEGC & $\begin{array}{c}1.385^{* * *} \\
(0.270)\end{array}$ & $\begin{array}{c}1.108^{* * * *} \\
(0.293)\end{array}$ & $\begin{array}{c}0.634 \\
(0.729)\end{array}$ & $\begin{array}{c}0.402 \\
(0.761)\end{array}$ \\
\hline $\log (\text { Assets })_{t-1}$ & & $\begin{array}{c}0.427^{* *} \\
(0.176)\end{array}$ & & $\begin{array}{c}0.426 * * * \\
(0.153)\end{array}$ \\
\hline $\log (\text { Employees })_{\mathrm{t}-1}$ & & $\begin{array}{c}0.066 \\
(0.041)\end{array}$ & & $\begin{array}{l}0.073^{*} \\
(0.037)\end{array}$ \\
\hline Debt to Assetst-1 & & $\begin{array}{l}-1.920 \\
(1.174)\end{array}$ & & $\begin{array}{c}-2.217^{* *} \\
(1.039)\end{array}$ \\
\hline Cash to Assets $t-1$ & & $\begin{array}{c}0.003 \\
(0.703)\end{array}$ & & $\begin{array}{c}0.113 \\
(0.650)\end{array}$ \\
\hline Capex to Assetst-1 & & $\begin{array}{l}1.306^{+} \\
(0.668)\end{array}$ & & $\begin{array}{c}1.451^{* * *} \\
(0.627)\end{array}$ \\
\hline R\&D to Assetst-1 & & $\begin{array}{l}-0.782 \\
(2.070)\end{array}$ & & $\begin{array}{l}-1.362 \\
(1.927)\end{array}$ \\
\hline $\log (\text { Age })_{t-1}$ & & $\begin{array}{l}-1.192 \\
(1.414)\end{array}$ & & $\begin{array}{l}-1.233 \\
(1.279)\end{array}$ \\
\hline Tobin's $Q_{t-1}$ & & $\begin{array}{l}-0.158 \\
(0.106)\end{array}$ & & $\begin{array}{c}-0.200^{* * *} \\
(0.098)\end{array}$ \\
\hline $\log (\text { Board Size })_{t-1}$ & & $\begin{array}{c}0.113 * * \\
(0.047)\end{array}$ & & $\begin{array}{c}0.123 * * * * \\
(0.045)\end{array}$ \\
\hline Board Independence $t_{t-1}$ & & $\begin{array}{l}0.591^{*} \\
(0.330)\end{array}$ & & $\begin{array}{c}0.682^{* *} \\
(0.320)\end{array}$ \\
\hline Stock Market Return $t-1$ & & $\begin{array}{c}-1.721^{*} \\
(1.005)\end{array}$ & & $\begin{array}{c}-1.811^{*} \\
(0.951)\end{array}$ \\
\hline Hot SPO Market & & $\begin{array}{l}-6.489 \\
(7.691)\end{array}$ & & $\begin{array}{c}-5.079 \\
(6.898)\end{array}$ \\
\hline Constant & $3.456^{* * *}$ & $3.082 * * *$ & -0.582 & -1.224 \\
\hline
\end{tabular}

\begin{tabular}{|c|c|c|c|}
\hline \multicolumn{4}{|c|}{ New Equity/Assetst-1 } \\
\hline \multicolumn{2}{|c|}{ OLS } & \multicolumn{2}{|c|}{ IV } \\
\hline (5) & (6) & $(7)$ & (8) \\
\hline \multirow{25}{*}{$\begin{array}{c}0.269^{* * *} \\
(0.077)\end{array}$} & $0.301 * * *$ & -0.175 & -0.140 \\
\hline & $(0.070)$ & $(0.196)$ & $(0.190)$ \\
\hline & $-0.256 * * *$ & & $-0.220^{* *}$ \\
\hline & $(0.096)$ & & $(0.088)$ \\
\hline & 0.007 & & 0.012 \\
\hline & $(0.010)$ & & $(0.010)$ \\
\hline & -0.144 & & -0.333 \\
\hline & $(0.291)$ & & $(0.331)$ \\
\hline & 0.034 & & 0.111 \\
\hline & $(0.200)$ & & $(0.204)$ \\
\hline & 0.218 & & 0.311 \\
\hline & $(0.238)$ & & $(0.257)$ \\
\hline & -0.143 & & -0.460 \\
\hline & $(0.399)$ & & $(0.377)$ \\
\hline & -0.531 & & $-0.487 *$ \\
\hline & $(0.441)$ & & $(0.412)$ \\
\hline & -0.022 & & -0.048 \\
\hline & $(0.028)$ & & $(0.029)$ \\
\hline & $0.035^{* *}$ & & $0.045^{* * *}$ \\
\hline & $(0.017)$ & & $(0.016)$ \\
\hline & 0.046 & & 0.112 \\
\hline & $(0.080)$ & & $(0.081)$ \\
\hline & -0.073 & & -0.068 \\
\hline & $(0.299)$ & & $(0.309)$ \\
\hline & $\begin{array}{c}0.051 \\
(1.328)\end{array}$ & & $\begin{array}{c}0.904 \\
(1.488)\end{array}$ \\
\hline 0.035 & $0.112 * * *$ & 0.066 & 0.036 \\
\hline
\end{tabular}

\begin{tabular}{cccc}
\multicolumn{3}{c}{ Log(New Debt) } \\
\hline \multicolumn{3}{c}{ OLS } & \multicolumn{3}{c}{ IV } \\
\hline $0.621^{* *}$ & $0.593^{* *}$ & $1.358^{*}$ & $1.801^{* *}$ \\
$(0.251)$ & $(0.269)$ & $(0.729)$ & $(0.745)$ \\
& -0.121 & & -0.119 \\
& $(0.269)$ & & $(0.247)$ \\
& -0.051 & & -0.062 \\
& $(0.050)$ & & $(0.049)$ \\
& -0.591 & & -0.082 \\
& $(1.399)$ & & $(1.344)$ \\
& -0.931 & & -1.118 \\
& $(0.684)$ & & $(0.668)$ \\
& 1.321 & & 1.073 \\
& $(0.850)$ & & $(0.840)$ \\
& 4.070 & & 5.063 \\
& $(3.003)$ & & $(2.602)$ \\
& $-4.722 * * *$ & & $-4.653^{* * *}$ \\
& $(1.605)$ & & $(1.473)$ \\
& -0.109 & & -0.038 \\
& $(0.128)$ & & $(0.119)$ \\
& $0.191 * * *$ & & $0.173 * *$ \\
& $(0.072)$ & & $(0.065)$ \\
& -0.107 & & -0.264 \\
& $(0.368)$ & & $(0.359)$ \\
-1.284 & & -1.131 \\
& $(1.113)$ & & $(1.010)$ \\
10.679 & & 8.266 \\
$(6.787)$ & & $(6.546)$ \\
0.802 & $5.199^{* *}$ & 0.732 & $2.844^{* *}$ \\
& &
\end{tabular}

\begin{tabular}{cccc}
\multicolumn{3}{c}{ New Debt/Assetst-1 } \\
\hline \multicolumn{3}{c}{ OLS } & \multicolumn{3}{c}{ IV } \\
\hline $0.169^{* *}$ & $0.165^{* *}$ & $(15)$ & $(16)$ \\
$(0.070)$ & $(0.076)$ & $(0.159)$ & $0.443^{* *}$ \\
& 0.012 & & $(0.189)$ \\
& $(0.076)$ & & -0.017 \\
& -0.012 & & $(0.071)$ \\
& $(0.011)$ & & -0.016 \\
& -0.270 & & $(0.011)$ \\
& $(0.435)$ & & -0.122 \\
& -0.123 & & $-0.405)$ \\
& $(0.155)$ & & $(0.149)$ \\
& -0.711 & & -0.540 \\
& $(0.470)$ & & $(0.414)$ \\
& -0.562 & & $-0.612^{*}$ \\
& $(0.349)$ & & $(0.329)$ \\
& 0.002 & & 0.019 \\
& $(0.026)$ & & $(0.026)$ \\
& $0.036^{* *}$ & & $0.030^{*}$ \\
& $(0.018)$ & & $(0.016)$ \\
& -0.005 & & -0.044 \\
& $(0.067)$ & & $(0.064)$ \\
& -0.040 & & -0.051 \\
& $(0.244)$ & & $(0.213)$ \\
& 1.683 & & 1.175 \\
& $(1.585)$ & & $(1.510)$ \\
0.041 & & 0.070 \\
& $(0.071)$ & & $(0.080)$ \\
0.843 & 0.838 & -0.029 & 0.252 \\
& & &
\end{tabular}




\begin{tabular}{|c|c|c|c|c|c|c|c|c|c|c|c|c|c|c|c|c|}
\hline & $(0.515)$ & $(1.072)$ & $(0.563)$ & (1.007) & $(0.746)$ & $(0.006)$ & $(0.159)$ & $(0.667)$ & $(0.944)$ & $(2.403)$ & $(0.618)$ & $(1.205)$ & $(0.577)$ & $(0.789)$ & $(0.140)$ & $(0.476)$ \\
\hline Float Terms & $\mathrm{Y}$ & $\mathrm{Y}$ & $\mathrm{Y}$ & $\mathrm{Y}$ & $\mathrm{Y}$ & $\mathrm{Y}$ & $\mathrm{Y}$ & $\mathrm{Y}$ & $\mathrm{Y}$ & $\mathrm{Y}$ & $\mathrm{Y}$ & $\mathrm{Y}$ & $\mathrm{Y}$ & $\mathrm{Y}$ & $\mathrm{Y}$ & $\mathrm{Y}$ \\
\hline Year/Industry FE & $\mathrm{Y}$ & $\mathrm{Y}$ & $\mathrm{Y}$ & $\mathrm{Y}$ & $\mathrm{Y}$ & $\mathrm{Y}$ & $\mathrm{Y}$ & $\mathrm{Y}$ & $\mathrm{Y}$ & $\mathrm{Y}$ & $\mathrm{Y}$ & $\mathrm{Y}$ & $\mathrm{Y}$ & $\mathrm{Y}$ & $\mathrm{Y}$ & $\mathrm{Y}$ \\
\hline Observations & 323 & 276 & 323 & 276 & 273 & 273 & 273 & 273 & 323 & 276 & 323 & 276 & 273 & 273 & 273 & 273 \\
\hline Adjusted $\mathrm{R}^{2}$ & 0.218 & 0.269 & 0.194 & 0.248 & 0.197 & 0.392 & 0.087 & 0.289 & 0.305 & 0.381 & 0.286 & 0.332 & 0.187 & 0.235 & 0.162 & 0.173 \\
\hline Durbin & & & 1.374 & 1.095 & & & 6.465 & 6.368 & & & 1.227 & 2.979 & & & 1.401 & 2.839 \\
\hline $\mathrm{p}$ (Durbin) & & & 0.241 & 0.295 & & & 0.011 & 0.012 & & & 0.268 & 0.084 & & & 0.237 & 0.092 \\
\hline $\mathrm{Wu}$ & & & 1.235 & 0.904 & & & 5.826 & 5.357 & & & 1.102 & 2.477 & & & 1.239 & 2.352 \\
\hline $\mathrm{p}(\mathrm{Wu})$ & & & 0.267 & 0.343 & & & 0.017 & 0.022 & & & 0.295 & 0.117 & & & 0.267 & 0.127 \\
\hline First-stage $\mathrm{R}^{2}$ & & & 0.175 & 0.202 & & & 0.202 & 0.218 & & & 0.175 & 0.202 & & & 0.192 & 0.204 \\
\hline First Stage F-stat & & & 35.663 & 27.101 & & & 36.978 & 25.309 & & & 35.663 & 27.101 & & & 36.774 & 23.724 \\
\hline
\end{tabular}


Table 3. EGC Fundraising by Listing Age

Table presents OLS regression estimates based on equation (1) where the dependent variables are various measures of issuance. New Equity $(D)$ is a dummy equal to one if the firm issued new equity via seasoned public offers (SPOs) during a fiscal year. New Debt $(D)$ is a dummy equal to one if the firm issued log-term debt during a fiscal year. The sample comprises firms that went public as an "Emerging Growth Company" (EGC) between April 6, 2012 and April 30, 2019. See Section 3.1 for a detailed description of the sample construction. To avoid the impact of confounding factors, the analysis is restricted to a bandwidth of $h=\$ 350$ million around the LAF cutoff (i.e., firms with float between $\$ 350$ and $\$ 1,050$ million in any given year). $E x E G C$ is a dummy equal to one for firms having a float above $\$ 700$ million at the end of second fiscal quarter that are subject to mandatory disclosure under the "Large Accelerated Filer" (LAF) regulation, and zero for firms whose float is below the threshold. IPO Year denotes the year in which the firm became a publicly traded company. In all regressions, industryyear fixed effects are included. Standard errors are clustered by firm and reported in parentheses. ***, **, and * denote significance at the $1 \%, 5 \%$, and $10 \%$ level, respectively. See Table A1 for a detailed description of the variables.

\begin{tabular}{|c|c|c|c|c|c|c|}
\hline & \multicolumn{3}{|c|}{ New Equity (D) } & \multicolumn{3}{|c|}{ New Debt (D) } \\
\hline & $(1)$ & (2) & (3) & (4) & (5) & $(6)$ \\
\hline \multirow[t]{2}{*}{$t=\mathrm{IPO}$ year +1} & 0.012 & 0.035 & 0.035 & 0.077 & 0.028 & 0.027 \\
\hline & $(0.105)$ & $(0.096)$ & $(0.096)$ & $(0.079)$ & $(0.083)$ & $(0.083)$ \\
\hline \multirow[t]{2}{*}{$t=\mathrm{IPO}$ year +2} & -0.167 & -0.119 & -0.122 & 0.022 & -0.043 & -0.040 \\
\hline & $(0.110)$ & $(0.107)$ & $(0.107)$ & $(0.081)$ & $(0.093)$ & $(0.093)$ \\
\hline \multirow[t]{2}{*}{$t=\mathrm{IPO}$ year +3} & $-0.334 * * *$ & $-0.331 * * *$ & $-0.337 * * *$ & 0.047 & -0.004 & -0.003 \\
\hline & $(0.103)$ & $(0.097)$ & $(0.098)$ & $(0.113)$ & $(0.115)$ & $(0.115)$ \\
\hline \multirow[t]{2}{*}{$t=\mathrm{IPO}$ year +4} & -0.022 & -0.034 & -0.034 & 0.043 & 0.013 & 0.018 \\
\hline & $(0.126)$ & $(0.116)$ & $(0.115)$ & $(0.105)$ & $(0.101)$ & $(0.102)$ \\
\hline \multirow[t]{2}{*}{$t=\mathrm{IPO}$ year +5} & -0.002 & 0.026 & 0.072 & -0.119 & -0.090 & $-0.197 * *$ \\
\hline & $(0.200)$ & $(0.156)$ & $(0.159)$ & $(0.193)$ & $(0.172)$ & $(0.097)$ \\
\hline \multirow{2}{*}{$t=\mathrm{IPO}$ year +6} & $0.315^{* * *}$ & $0.305 * *$ & $0.306 * *$ & $-0.145^{*}$ & $-0.371 * * *$ & $-0.366 * * *$ \\
\hline & $(0.109)$ & $(0.118)$ & $(0.118)$ & $(0.085)$ & $(0.108)$ & $(0.108)$ \\
\hline \multirow[t]{2}{*}{ ExEGC } & 0.113 & 0.025 & 0.025 & -0.002 & -0.021 & -0.011 \\
\hline & $(0.157)$ & $(0.136)$ & $(0.136)$ & $(0.097)$ & $(0.113)$ & $(0.113)$ \\
\hline \multirow[t]{2}{*}{$t=\mathrm{IPO}$ year $+1 \times$ ExEGC } & 0.013 & 0.022 & 0.022 & 0.040 & 0.053 & 0.050 \\
\hline & $(0.186)$ & $(0.157)$ & $(0.156)$ & $(0.104)$ & $(0.121)$ & $(0.121)$ \\
\hline \multirow[t]{2}{*}{$t=\mathrm{IPO}$ year $+2 \times$ ExEGC } & 0.039 & 0.031 & 0.035 & 0.020 & 0.026 & 0.010 \\
\hline & $(0.198)$ & $(0.169)$ & $(0.170)$ & $(0.134)$ & $(0.144)$ & $(0.144)$ \\
\hline \multirow[t]{2}{*}{$t=\mathrm{IPO}$ year $+3 \times$ ExEGC } & 0.195 & $0.310 * *$ & $0.315 * *$ & -0.010 & -0.021 & -0.022 \\
\hline & $(0.173)$ & $(0.150)$ & $(0.150)$ & $(0.145)$ & $(0.148)$ & $(0.147)$ \\
\hline \multirow[t]{2}{*}{$t=\mathrm{IPO}$ year $+4 \times$ ExEGC } & -0.079 & -0.005 & -0.004 & 0.085 & 0.018 & 0.009 \\
\hline & $(0.172)$ & $(0.145)$ & $(0.145)$ & $(0.161)$ & $(0.133)$ & $(0.132)$ \\
\hline \multirow[t]{2}{*}{$t=\mathrm{IPO}$ year $+5 \times$ ExEGC } & 0.025 & 0.065 & 0.020 & 0.246 & 0.140 & 0.240 \\
\hline & $(0.210)$ & $(0.158)$ & $(0.160)$ & $(0.249)$ & $(0.210)$ & $(0.152)$ \\
\hline \multirow[t]{2}{*}{$t=\mathrm{IPO}$ year $+6 \times$ ExEGC } & $-0.513^{* * *}$ & $-0.424 * *$ & $-0.480 * * *$ & 0.373 & 0.701 & $1.048 * * *$ \\
\hline & $(0.163)$ & $(0.173)$ & $(0.152)$ & $(0.470)$ & $(0.446)$ & $(0.183)$ \\
\hline \multirow[t]{2}{*}{ Constant } & $0.426 * * *$ & $0.388 * * *$ & -0.242 & -0.000 & 0.023 & 0.484 \\
\hline & $(0.128)$ & $(0.140)$ & $(0.252)$ & $(0.000)$ & $(0.222)$ & $(0.437)$ \\
\hline Firm Controls & $\mathrm{N}$ & $\mathrm{Y}$ & $\mathrm{Y}$ & $\mathrm{N}$ & $\mathrm{Y}$ & $\mathrm{Y}$ \\
\hline Macro Controls & $\mathrm{N}$ & $\mathrm{N}$ & $\mathrm{Y}$ & $\mathrm{N}$ & $\mathrm{N}$ & $\mathrm{Y}$ \\
\hline Industry/Year FE & $\mathrm{Y}$ & $\mathrm{Y}$ & $\mathrm{Y}$ & $\mathrm{Y}$ & $\mathrm{Y}$ & $\mathrm{Y}$ \\
\hline Observations & 819 & 819 & 807 & 819 & 819 & 807 \\
\hline Adjusted $\mathrm{R}^{2}$ & 0.390 & 0.468 & 0.464 & 0.408 & 0.501 & 0.504 \\
\hline
\end{tabular}


Table 4. Impact of EGC Status Loss on Internal Investments

Table presents regression discontinuity (RD) estimates where the dependent variables are various measures of internal investments. The OLS estimates are based on equation (1); the IV estimates are based on equations (2.1) and (2.2). Panel (a) considers four measures of internal investments: capital expenditure (Capex), investments in property, plant, and equipment $(P P E), \mathrm{R} \& \mathrm{D}$ expenditure $(R \& D)$, and number of employees (Employees); each standardized by lagged sales. Panel (b) considers the year-on-year change in these investment measures relative to total sales. New Equity is the dollar value of common stock issued by the firm via seasoned public offers (SPOs) during a fiscal year. New Debt is the dollar value of total long-term debt issued during a fiscal year. The sample comprises firms that went public as an "Emerging Growth Company" (EGC) between April 6, 2012 and April 30, 2019. See Section 3.1 for a detailed description of the sample construction. ExEGC is a dummy equal to one for firms having a float above $\$ 700$ million at the end of second fiscal quarter that are subject to mandatory disclosure under the "Large Accelerated Filer" (LAF) regulation, and zero for firms whose float is below the threshold. To minimize the effect of confounding factors, the analysis is restricted to firms whose float is within a bandwidth $h=\$ 250$ million around the LAF cutoff. For the IV regressions, ExEGC is the predicted treatment based on the first-stage model (2.1) using the variable $P F 700$ as an instrument. $P F 700$ is equal to one if the firm's float six months prior to the second fiscal quarter exceeds $\$ 700$ million, and zero otherwise. In all regressions, industry and year fixed effects are included. Standard errors are clustered by firm, and are reported in parentheses. $* * *, * *$, and $*$ denote significance at the $1 \%, 5 \%$, and $10 \%$ level, respectively. See Table A1 for a detailed description of the variables.

a) Investments by EGC status

\begin{tabular}{|c|c|c|c|c|c|c|c|c|}
\hline & \multicolumn{2}{|c|}{ Capex/Sales } & \multicolumn{2}{|c|}{ PPE/Sales } & \multicolumn{2}{|c|}{ R\&D/Sales } & \multicolumn{2}{|c|}{ Employees/Sales } \\
\hline & $\begin{array}{l}\text { OLS } \\
(1)\end{array}$ & $\begin{array}{l}\text { IV } \\
\text { (2) }\end{array}$ & $\begin{array}{l}\text { OLS } \\
(3)\end{array}$ & $\begin{array}{l}\text { IV } \\
\text { (4) }\end{array}$ & $\begin{array}{l}\text { OLS } \\
(5)\end{array}$ & $\begin{array}{l}\text { IV } \\
(6)\end{array}$ & $\begin{array}{l}\text { OLS } \\
(7)\end{array}$ & $\begin{array}{l}\text { IV } \\
(8)\end{array}$ \\
\hline ExEGC & $\begin{array}{l}-0.026 \\
(0.021) \\
\end{array}$ & $\begin{array}{c}-0.186^{* * *} \\
(0.060) \\
\end{array}$ & $\begin{array}{l}-0.136 \\
(0.084) \\
\end{array}$ & $\begin{array}{c}-0.638^{* * *} \\
(0.236) \\
\end{array}$ & $\begin{array}{c}0.008 \\
(0.024) \\
\end{array}$ & $\begin{array}{c}-0.137 * * \\
(0.062) \\
\end{array}$ & $\begin{array}{l}-0.000 \\
(0.001)\end{array}$ & $\begin{array}{c}-0.005 * * \\
(0.002) \\
\end{array}$ \\
\hline Controls & $\mathrm{Y}$ & $\mathrm{Y}$ & $\mathrm{Y}$ & $\mathrm{Y}$ & $\mathrm{Y}$ & $\mathrm{Y}$ & $\mathrm{Y}$ & $\mathrm{Y}$ \\
\hline Industry/Year FE & $\mathrm{Y}$ & $\mathrm{Y}$ & $\mathrm{Y}$ & $\mathrm{Y}$ & $\mathrm{Y}$ & $\mathrm{Y}$ & $\mathrm{Y}$ & $\mathrm{Y}$ \\
\hline $\begin{array}{l}\text { Observations } \\
\text { Adjusted R }{ }^{2}\end{array}$ & $\begin{array}{c}276 \\
0.247\end{array}$ & $\begin{array}{c}276 \\
0.092\end{array}$ & $\begin{array}{c}276 \\
0.449\end{array}$ & $\begin{array}{c}276 \\
0.364\end{array}$ & $\begin{array}{c}276 \\
0.200\end{array}$ & $\begin{array}{c}276 \\
0.073\end{array}$ & $\begin{array}{c}276 \\
0.287\end{array}$ & $\begin{array}{c}276 \\
0.185\end{array}$ \\
\hline $\begin{array}{l}\text { First-Stage } \mathrm{R}^{2} \\
\text { First Stage F-stat }\end{array}$ & & $\begin{array}{c}0.185 \\
29.823 \\
\end{array}$ & & $\begin{array}{c}0.185 \\
29.823 \\
\end{array}$ & & $\begin{array}{c}0.185 \\
29.823 \\
\end{array}$ & & $\begin{array}{c}0.185 \\
29.823 \\
\end{array}$ \\
\hline
\end{tabular}

b) Investment growth by EGC status and fundraising

\begin{tabular}{|c|c|c|c|c|c|c|c|c|}
\hline & \multicolumn{2}{|c|}{$\Delta_{1 y}$ Capex/Sales } & \multicolumn{2}{|c|}{$\Delta_{1 \mathrm{y}} \mathrm{PPE} /$ Sales } & \multicolumn{2}{|c|}{$\Delta_{1 y} R \& D /$ Sales } & \multicolumn{2}{|c|}{$\Delta_{1 \mathrm{y}}$ Employee/Sales } \\
\hline & $\begin{array}{l}\text { OLS } \\
\text { (1) }\end{array}$ & $\begin{array}{l}\text { IV } \\
(2)\end{array}$ & $\begin{array}{l}\text { OLS } \\
\text { (3) }\end{array}$ & $\begin{array}{l}\text { IV } \\
\text { (4) }\end{array}$ & $\begin{array}{l}\text { OLS } \\
(5)\end{array}$ & $\begin{array}{l}\text { IV } \\
\text { (6) }\end{array}$ & $\begin{array}{l}\text { OLS } \\
\text { (7) }\end{array}$ & $\begin{array}{l}\text { IV } \\
\text { (8) }\end{array}$ \\
\hline \multirow[t]{2}{*}{ ExEGC } & 0.009 & -0.068 & -0.032 & $-0.278 * * *$ & 0.100 & -0.004 & -0.462 & -0.740 \\
\hline & $(0.021)$ & $(0.043)$ & $(0.063)$ & $(0.100)$ & $(0.095)$ & $(0.044)$ & $(0.735)$ & $(1.458)$ \\
\hline \multirow[t]{2}{*}{$\log (\text { New Equity })_{t-1}$} & -0.013 & $-0.018 * * *$ & -0.025 & $-0.041 * *$ & $-0.020 * * *$ & $-0.027 * * *$ & $-0.580 * *$ & $-0.598 * * *$ \\
\hline & $(0.007)$ & $(0.007)$ & $(0.027)$ & $(0.020)$ & $(0.003)$ & $(0.006)$ & $(0.204)$ & $(0.190)$ \\
\hline \multirow[t]{2}{*}{$\log (\text { New Debt })_{\mathrm{t}-1}$} & $0.016^{*}$ & $0.012 *$ & 0.012 & 0.001 & 0.021 & 0.016 & -0.039 & -0.051 \\
\hline & $(0.008)$ & $(0.007)$ & $(0.022)$ & $(0.018)$ & $(0.016)$ & $(0.011)$ & $(0.249)$ & $(0.216)$ \\
\hline \multirow[t]{2}{*}{ ExEGC $\times \log (\text { New Equity })_{t-1}$} & $0.011 *$ & $0.022 * * *$ & 0.040 & $0.076 * * *$ & $0.035 * * *$ & $0.051 * * *$ & $0.537 * *$ & $0.579 * *$ \\
\hline & $(0.005)$ & $(0.007)$ & $(0.031)$ & $(0.024)$ & $(0.003)$ & $(0.012)$ & $(0.213)$ & $(0.281)$ \\
\hline \multirow[t]{2}{*}{ ExEGC $\times \log (\text { New Debt })_{t-1}$} & -0.015 & -0.006 & -0.003 & $0.023 * *$ & -0.024 & -0.013 & -0.039 & -0.010 \\
\hline & $(0.009)$ & $(0.009)$ & $(0.013)$ & $(0.010)$ & $(0.017)$ & $(0.011)$ & $(0.155)$ & $(0.212)$ \\
\hline Controls & $\mathrm{Y}$ & $\mathrm{Y}$ & $\mathrm{Y}$ & $\mathrm{Y}$ & $\mathrm{Y}$ & $\mathrm{Y}$ & $\mathrm{Y}$ & $\mathrm{Y}$ \\
\hline Industry/Year FE & $\mathrm{Y}$ & $\mathrm{Y}$ & $\mathrm{Y}$ & $\mathrm{Y}$ & $\mathrm{Y}$ & $\mathrm{Y}$ & $\mathrm{Y}$ & $\mathrm{Y}$ \\
\hline Observations & 276 & 276 & 276 & 276 & 276 & 276 & 276 & 276 \\
\hline Adjusted $\mathrm{R}^{2}$ & 0.049 & 0.013 & 0.159 & 0.108 & 0.046 & 0.037 & 0.013 & 0.012 \\
\hline First-stage $\mathrm{R}^{2}$ & & 0.504 & & 0.504 & & 0.504 & & 0.504 \\
\hline First Stage F-stat & & 4.763 & & 4.763 & & 4.763 & & 4.763 \\
\hline
\end{tabular}


Table 5. Impact of EGC Status Loss on External Investments

Table presents regression discontinuity (RD) estimates where the dependent variables are various measures of external investments. The OLS estimates are based on equation (1); the IV estimates are based on equations (2.1) and (2.2). We considers three measures of external investments: a dummy indicating if the firm made at least one acquisition (Acquisition), the log dollar value of acquisitions (Acquisition Value), and a dummy equal to one if all acquisitions are paid for entirely in cash (All Cash Acquisitions). New Equity is the dollar value of common stock issued by the firm via seasoned public offers (SPOs) during a fiscal year. New Debt is the dollar value of total long-term debt issued during a fiscal year. The sample comprises firms that went public as an "Emerging Growth Company" (EGC) between April 6, 2012 and April 30, 2019. See Section 3.1 for a detailed description of the sample construction. ExEGC is a dummy equal to one for firms having a float above $\$ 700$ million at the end of second fiscal quarter that are subject to mandatory disclosure under the "Large Accelerated Filer" (LAF) regulation, and zero for firms whose float is below the threshold. To minimize the effect of confounding factors, the analysis is restricted to firms whose float is within a bandwidth $h=\$ 250$ million around the LAF cutoff. For the IV regressions, ExEGC is the predicted treatment based on the first-stage model (2.1) using the variable $P F 700$ as an instrument. $P F 700$ is equal to one if the firm's float six months prior to the second fiscal quarter exceeds $\$ 700$ million, and zero otherwise. In all regressions, industry and year fixed effects are included. Standard errors are clustered by firm, and reported in parentheses. $* * *, * *$, and $*$ denote significance at the $1 \%, 5 \%$, and $10 \%$ level, respectively. See Table A1 for a description of the variables.

a) Acquisitions by EGC status

\begin{tabular}{|c|c|c|c|c|c|c|}
\hline & \multicolumn{2}{|c|}{ Acquisition (D) } & \multicolumn{2}{|c|}{ Log (Acquisition Value) } & \multicolumn{2}{|c|}{ All Cash Acquisitions (D) } \\
\hline & $\begin{array}{l}\text { OLS } \\
(1)\end{array}$ & $\begin{array}{l}\text { IV } \\
\text { (2) } \\
\end{array}$ & $\begin{array}{l}\text { OLS } \\
(3)\end{array}$ & $\begin{array}{l}\text { IV } \\
(4) \\
\end{array}$ & $\begin{array}{c}\text { OLS } \\
(5) \\
\end{array}$ & $\begin{array}{l}\text { IV } \\
(6) \\
\end{array}$ \\
\hline ExEGC & $\begin{array}{c}-0.072 * * \\
(0.026) \\
\end{array}$ & $\begin{array}{c}-0.183^{* * * *} \\
(0.068)\end{array}$ & $\begin{array}{c}-0.258 * * \\
(0.119) \\
\end{array}$ & $\begin{array}{c}-1.022 * * * \\
(0.269) \\
\end{array}$ & $\begin{array}{c}-0.050^{*} \\
(0.025) \\
\end{array}$ & $\begin{array}{c}-0.151^{* * *} \\
(0.036)\end{array}$ \\
\hline $\begin{array}{l}\text { Controls } \\
\text { Industry/Year FE }\end{array}$ & $\begin{array}{l}\mathrm{Y} \\
\mathrm{Y}\end{array}$ & $\begin{array}{l}\mathrm{Y} \\
\mathrm{Y}\end{array}$ & $\begin{array}{l}\mathrm{Y} \\
\mathrm{Y}\end{array}$ & $\begin{array}{l}\mathrm{Y} \\
\mathrm{Y}\end{array}$ & $\begin{array}{l}\mathrm{Y} \\
\mathrm{Y}\end{array}$ & $\begin{array}{l}\mathrm{Y} \\
\mathrm{Y}\end{array}$ \\
\hline $\begin{array}{l}\text { Observations } \\
\text { Adjusted R }\end{array}$ & $\begin{array}{c}276 \\
0.131 \\
\end{array}$ & $\begin{array}{c}276 \\
0.086\end{array}$ & $\begin{array}{c}276 \\
0.111 \\
\end{array}$ & $\begin{array}{c}276 \\
0.012\end{array}$ & $\begin{array}{c}276 \\
0.209\end{array}$ & $\begin{array}{c}276 \\
0.163 \\
\end{array}$ \\
\hline $\begin{array}{l}\text { First-Stage } \mathrm{R}^{2} \\
\text { First Stage F-stat }\end{array}$ & & $\begin{array}{l}0.172 \\
7.269 \\
\end{array}$ & & $\begin{array}{l}0.172 \\
7.269 \\
\end{array}$ & & $\begin{array}{l}0.172 \\
7.269 \\
\end{array}$ \\
\hline
\end{tabular}

b) Acquisitions by EGC status and fundraising

\begin{tabular}{|c|c|c|c|c|c|c|}
\hline & \multicolumn{2}{|c|}{ Acquisition (D) } & \multicolumn{2}{|c|}{ Log (Acquisition Value) } & \multicolumn{2}{|c|}{ All Cash Acquisitions (D) } \\
\hline & OLS & IV & OLS & IV & OLS & IV \\
\hline & $(1)$ & (2) & (3) & $(4)$ & (5) & $(6)$ \\
\hline \multirow[t]{2}{*}{ ExEGC } & -0.055 & $-0.167 * *$ & -0.244 & $-0.998 * * *$ & -0.039 & $-0.130 * * *$ \\
\hline & $(0.034)$ & $(0.073)$ & $(0.190)$ & $(0.239)$ & $(0.028)$ & $(0.049)$ \\
\hline \multirow[t]{2}{*}{ Log (New Equity $)_{t-1}$} & 0.006 & -0.004 & 0.004 & -0.063 & -0.003 & -0.011 \\
\hline & $(0.015)$ & $(0.008)$ & $(0.085)$ & $(0.054)$ & $(0.010)$ & $(0.007)$ \\
\hline \multirow[t]{2}{*}{$\log (\text { New Debt })_{t-1}$} & 0.005 & 0.001 & 0.029 & 0.003 & 0.005 & 0.002 \\
\hline & $(0.020)$ & $(0.020)$ & $(0.084)$ & $(0.081)$ & $(0.019)$ & $(0.018)$ \\
\hline \multirow[t]{2}{*}{ ExEGC $\times \log (\text { New Equity })_{t-1}$} & 0.002 & $0.018 * * *$ & 0.044 & $0.156^{* * *}$ & 0.007 & $0.021 * * *$ \\
\hline & $(0.015)$ & $(0.006)$ & $(0.088)$ & $(0.050)$ & $(0.011)$ & $(0.006)$ \\
\hline \multirow[t]{2}{*}{ ExEGC $\times \log (\text { New Debt })_{t-1}$} & -0.007 & 0.004 & -0.047 & 0.032 & -0.011 & -0.001 \\
\hline & $(0.014)$ & $(0.018)$ & $(0.072)$ & $(0.074)$ & $(0.014)$ & $(0.016)$ \\
\hline Controls & $\mathrm{Y}$ & $\mathrm{Y}$ & $\mathrm{Y}$ & $\mathrm{Y}$ & $\mathrm{Y}$ & $\mathrm{Y}$ \\
\hline Industry/Year FE & $\mathrm{Y}$ & $\mathrm{Y}$ & $\mathrm{Y}$ & $\mathrm{Y}$ & $\mathrm{Y}$ & $\mathrm{Y}$ \\
\hline Observations & 276 & 276 & 276 & 276 & 276 & 276 \\
\hline Adjusted $\mathrm{R}^{2}$ & 0.048 & 0.024 & 0.051 & 0.071 & 0.062 & 0.042 \\
\hline First-stage $\mathrm{R}^{2}$ & & 0.566 & & 0.566 & & 0.566 \\
\hline First Stage F-stat & & 17.342 & & 17.342 & & 17.342 \\
\hline
\end{tabular}


Table 6. EGC Status Loss and Growth Opportunities

Table presents regression discontinuity (RD) estimates where the dependent variables are various measures of growth opportunities. The OLS/Probit estimates are based on equation (1); the IV estimates are based on equations (2.1) and (2.2). The dependent variable in Models (1) - (2) is the firm's Tobin's $q$ in a given year. The dependent variable in Models (3) - (4) is a dummy equal to one if the firm's Tobin's $q$ exceeds $q_{0}$ (Tobin's $q$ in the IPO year). Listing Age denotes the number of years the firm has been a public company. The sample comprises firms that went public as an "Emerging Growth Company" (EGC) between April 6, 2012 and April 30, 2019. See Section 3.1 for a detailed description of the sample construction. ExEGC is a dummy equal to one for firms having a float above $\$ 700$ million at the end of second fiscal quarter that are subject to mandatory disclosure under the "Large Accelerated Filer" (LAF) regulation, and zero for firms whose float is below the threshold. To minimize the effect of confounding factors, the analysis is restricted to firms whose float is within a bandwidth $h=\$ 250$ million around the LAF cutoff. For the IV regressions, ExEGC is the predicted treatment based on the first-stage model (2.1) using the variable $P F 700$ as an instrument. $P F 700$ is equal to one if the firm's float six months prior to the second fiscal quarter exceeds $\$ 700$ million, and zero otherwise. In all regressions, industry-year fixed effects are included. Standard errors are clustered by firm, and reported in parentheses. $* * *, * *$, and $*$ denote significance at the $1 \%, 5 \%$, and $10 \%$ level, respectively. See Table A1 for a description of the variables.

\begin{tabular}{|c|c|c|c|c|}
\hline & \multicolumn{2}{|c|}{ Panel A: Tobin's $q$} & \multicolumn{2}{|c|}{ Panel B: Tobin's $q>q_{0}$} \\
\hline & $\begin{array}{c}\text { OLS } \\
(1)\end{array}$ & $\begin{array}{l}\text { IV } \\
(2) \\
\end{array}$ & $\begin{array}{l}\text { Probit } \\
(3)\end{array}$ & $\begin{array}{l}\text { IV } \\
(4) \\
\end{array}$ \\
\hline ExEGC & $\begin{array}{c}2.920 * * * \\
(0.731)\end{array}$ & $\begin{array}{c}3.674 * * \\
(1.794)\end{array}$ & $\begin{array}{c}2.047 * * * \\
(0.579)\end{array}$ & $\begin{array}{c}1.298 * * * \\
(0.459)\end{array}$ \\
\hline Log (Listing Age) & $\begin{array}{c}0.088 \\
(0.398)\end{array}$ & $\begin{array}{c}0.418 \\
(0.582)\end{array}$ & $\begin{array}{c}-0.074 \\
(0.444)\end{array}$ & $\begin{array}{c}0.238 \\
(0.167)\end{array}$ \\
\hline ExEGC $\times$ Log (Listing Age $)$ & $\begin{array}{c}-1.631^{* * *} * \\
(0.571) \\
\end{array}$ & $\begin{array}{c}-2.389^{* *} \\
(1.176) \\
\end{array}$ & $\begin{array}{c}-1.054^{* *} \\
(0.481) \\
\end{array}$ & $\begin{array}{c}-0.892 * * * \\
(0.313) \\
\end{array}$ \\
\hline Controls & $\mathrm{Y}$ & $\mathrm{Y}$ & $\mathrm{Y}$ & $\mathrm{Y}$ \\
\hline Industry-Year FE & $\mathrm{Y}$ & $\mathrm{Y}$ & $\mathrm{Y}$ & $\mathrm{Y}$ \\
\hline $\begin{array}{l}\text { Observations } \\
\text { Adjusted/Pseudo R }\end{array}$ & $\begin{array}{c}276 \\
0.331\end{array}$ & $\begin{array}{c}276 \\
0.327\end{array}$ & $\begin{array}{c}276 \\
0.234\end{array}$ & $\begin{array}{c}276 \\
0.124\end{array}$ \\
\hline First-Stage $\mathrm{R}^{2}$ & & 0.176 & & 0.176 \\
\hline First Stage F-stat & & 15.729 & & 15.729 \\
\hline
\end{tabular}


Table 7. Which Factors Affect Growth Opportunities?

Table presents regression discontinuity (RD) estimates where the dependent variable measures growth opportunities. The OLS estimates are based on equation (1); the IV estimates are based on equations (2.1) and (2.2). The dependent variable is the firm's Tobin's $q$ in a given year. In panel (a), we investigate whether firms time the raising of their funds to sponsor future growth. New Equity is the dollar value of common stock issued by the firm via seasoned public offers (SPOs) during a fiscal year. New Debt is the dollar value of total long-term debt issued during a fiscal year. In panel (b), we explore which investment policies (internal and external) affect future growth opportunities. Panel (b) shows IV estimates only. See Table A6 in the online appendix for the corresponding OLS results. The sample comprises firms that went public as an "Emerging Growth Company" (EGC) between April 6, 2012 and April 30, 2019. See Section 3.1 for a detailed description of the sample construction. ExEGC is a dummy equal to one for firms having a float above $\$ 700$ million at the end of second fiscal quarter that are subject to mandatory disclosure under the "Large Accelerated Filer" (LAF) regulation, and zero for firms whose float is below the threshold. To minimize the effect of confounding factors, the analysis is restricted to firms whose float is within a bandwidth $h=\$ 250$ million around the LAF cutoff. For the IV regressions, ExEGC is the predicted treatment based on the first-stage model (2.1) using the variable $P F 700$ as an instrument. $P F 700$ is equal to one if the firm's float six months prior to the second fiscal quarter exceeds $\$ 700$ million, and zero otherwise. In all regressions, industry-year fixed effects are included. Standard errors are clustered by firm, and reported in parentheses. ***,**, and * denote significance at the $1 \%, 5 \%$, and $10 \%$ level, respectively. See Table A1 for a description of the variables.

a) Fundraising timing

\begin{tabular}{|c|c|c|c|c|}
\hline & \multicolumn{4}{|c|}{ Dependent Variable: Tobin's $q$} \\
\hline & \multicolumn{2}{|c|}{ OLS } & \multicolumn{2}{|c|}{ IV } \\
\hline & (1) & (2) & (3) & (4) \\
\hline \multirow[t]{2}{*}{ ExEGC } & $1.066^{* * *}$ & $0.331 * *$ & 0.758 & 0.303 \\
\hline & $(0.237)$ & $(0.117)$ & $(0.522)$ & $(0.770)$ \\
\hline \multirow[t]{2}{*}{ Log (New Equity) $)_{t-1}$} & 0.081 & $-0.094 * *$ & $0.079 *$ & -0.096 \\
\hline & $(0.042)$ & $(0.029)$ & $(0.035)$ & $(0.069)$ \\
\hline \multirow[t]{2}{*}{$\log (\text { New Debt })_{t-1}$} & -0.105 & $-0.127^{*}$ & -0.100 & $-0.128^{*}$ \\
\hline & $(0.082)$ & $(0.052)$ & $(0.067)$ & $(0.051)$ \\
\hline \multirow[t]{2}{*}{ ExEGC $\times \log (\text { New Equity })_{t-1}$} & & $0.330 * * *$ & & $0.335^{* *}$ \\
\hline & & $(0.073)$ & & $(0.120)$ \\
\hline \multirow[t]{2}{*}{ ExEGC $\times \log (\text { New Debt })_{t-1}$} & & 0.053 & & 0.056 \\
\hline & & $(0.076)$ & & $(0.110)$ \\
\hline Controls & $\bar{Y}$ & $\mathrm{Y}$ & $\mathrm{Y}$ & $\mathrm{Y}$ \\
\hline Industry FE & $\mathrm{Y}$ & $\mathrm{Y}$ & $\mathrm{Y}$ & $\mathrm{Y}$ \\
\hline Year FE & $\mathrm{Y}$ & $\mathrm{Y}$ & $\mathrm{Y}$ & $\mathrm{Y}$ \\
\hline Observations & 276 & 276 & 276 & 276 \\
\hline Adjusted $\mathrm{R}^{2}$ & 0.604 & 0.631 & 0.600 & 0.631 \\
\hline First-Stage $\mathrm{R}^{2}$ & & & 0.164 & 0.545 \\
\hline First-stage F-stat & & & 7.91 & 5.596 \\
\hline
\end{tabular}


b) Investment channels

\begin{tabular}{|c|c|c|c|c|c|c|}
\hline & \multicolumn{6}{|c|}{ Tobin's $q$} \\
\hline & (1) & (2) & (3) & (4) & (5) & (6) \\
\hline ExEGC & $\begin{array}{l}-0.082 \\
(1.092)\end{array}$ & $\begin{array}{l}-0.216 \\
(0.982)\end{array}$ & $\begin{array}{c}0.107 \\
(0.863)\end{array}$ & $\begin{array}{c}0.520 \\
(0.832)\end{array}$ & $\begin{array}{c}0.540 \\
(0.800)\end{array}$ & $\begin{array}{c}0.372 \\
(0.863)\end{array}$ \\
\hline Internal Investments & & & & & & \\
\hline Capex/Sales & $\begin{array}{l}-1.294 \\
(2.453)\end{array}$ & & & & & \\
\hline ExEGC $\times$ Capex $/$ Sales & $\begin{array}{c}2.394 \\
(4.079)\end{array}$ & & & & & \\
\hline PPE/Sales & & $\begin{array}{l}-0.306 \\
(0.367)\end{array}$ & & & & \\
\hline ExEGC $\times$ PPE/Sales & & $\begin{array}{l}1.035 \\
(1.166)\end{array}$ & & & & \\
\hline R\&D/Sales & & & $\begin{array}{l}-0.025 \\
(0.014)\end{array}$ & & & \\
\hline ExEGC $\times$ R\&D/Sales & & & $\begin{array}{l}-0.009 \\
(0.057)\end{array}$ & & & \\
\hline External Investments & & & & & & \\
\hline Acquisition (D) & & & & $\begin{array}{c}1.767 * * * \\
(0.413)\end{array}$ & & \\
\hline ExEGC $\times$ Acquisition (D) & & & & $\begin{array}{l}-2.041 \\
(1.066)\end{array}$ & & \\
\hline Log (Acquisition Value) & & & & & $\begin{array}{c}0.425 * * * \\
(0.072)\end{array}$ & \\
\hline ExEGC $\times \log ($ Acquisition Value $)$ & & & & & $\begin{array}{c}-0.601 * * \\
(0.209)\end{array}$ & \\
\hline All Cash Acquisition (D) & & & & & & $\begin{array}{c}2.449 * * * \\
(0.400)\end{array}$ \\
\hline ExEGC $\times$ All Cash Acquisition (D) & & & & & & $\begin{array}{c}-3.654 * * * \\
(0.919)\end{array}$ \\
\hline Constant & $\begin{array}{c}2.213 \\
(2.415) \\
\end{array}$ & $\begin{array}{c}1.273 \\
(2.526) \\
\end{array}$ & $\begin{array}{c}1.214 \\
(2.735) \\
\end{array}$ & $\begin{array}{l}1.448 \\
(2.707) \\
\end{array}$ & $\begin{array}{c}2.022 \\
(2.607) \\
\end{array}$ & $\begin{array}{c}1.435 \\
(3.073) \\
\end{array}$ \\
\hline Controls & $\mathrm{Y}$ & $\mathrm{Y}$ & $\mathrm{Y}$ & $\mathrm{Y}$ & $\mathrm{Y}$ & $\mathrm{Y}$ \\
\hline Industry FE & Y & $\mathrm{Y}$ & $\mathrm{Y}$ & $\mathrm{Y}$ & $\mathrm{Y}$ & $\mathrm{Y}$ \\
\hline Year FE & $\mathrm{Y}$ & $\mathrm{Y}$ & $\mathrm{Y}$ & $\mathrm{Y}$ & $\mathrm{Y}$ & $\mathrm{Y}$ \\
\hline Observations & 197 & 197 & 197 & 197 & 197 & 197 \\
\hline Adjusted $\mathrm{R}^{2}$ & 0.518 & 0.495 & 0.531 & 0.538 & 0.534 & 0.521 \\
\hline First-Stage $\mathrm{R}^{2}$ & 0.234 & 0.232 & 0.233 & 0.245 & 0.245 & 0.241 \\
\hline First Stage F-stat & 24.980 & 5.191 & 31.409 & 12.746 & 21.894 & 9.390 \\
\hline
\end{tabular}




\section{Table 8. Impact of EGC Status Loss on Operating Efficiency}

Table presents regression discontinuity (RD) estimates where the dependent variables are various proxies denoting operational efficiency. The OLS estimates are based on equation (1); the IV estimates are based on equations (2.1) and (2.2). The dependent variable in Models (1) - (2) is the firm's total sales scaled by total assets (Sales/Assets). The dependent variable in Models (3) - (4) is return on assets $(R O A)$. The dependent variable in Models $(5)-(6)$ is a dummy indicating if the firm had a net income below zero in a given year. The dependent variable in Models (7) - (8) is a measure of the firm's financial constraints $(K Z$ Index), based on Kaplan and Zingales (1997). We follow Lamont, Polk and Saaá-Requejo (2001) and compute this index as $1.0001909 \times[(I B+D P) / P P E N T T-1]+0.2826389 \times[(S I Z E) / A T]+3.139193 \times[(D L T T+D L C) /(D L T T+D L C+S E Q)]-39.3678$ $\times[(D V C+D V P) / P P E N T T-1]-1.314759 \times[C H E / A T T-1]$. SIZE is logarithm of the market value of assets at beginning of the year, and is $A T-C E Q+(C S H O \times P R C C F)-T X T B$. Data for the variables used in estimating the KZ-Index are obtained from Compustat. The sample comprises firms that went public as an "Emerging Growth Company" (EGC) between April 6, 2012 and April 30, 2019. See Section 3.1 for a detailed description of the sample construction. ExEGC is a dummy equal to one for firms having a float above $\$ 700$ million at the end of second fiscal quarter that are subject to mandatory disclosure under the "Large Accelerated Filer" (LAF) regulation, and zero for firms whose float is below the threshold. To minimize the effect of confounding factors, the analysis is restricted to firms whose float is within a bandwidth $h=\$ 250$ million around the LAF cutoff. For the IV regressions, ExEGC is the predicted treatment based on the first-stage model (2.1) using the variable $P F 700$ as an instrument. $P F 700$ is equal to one if the firm's float six months prior to the second fiscal quarter exceeds $\$ 700$ million, and zero otherwise. In all regressions, industry and year fixed effects are included. Standard errors are clustered by firm, and reported in parentheses. $* * *, * *$, and $*$ denote significance at the $1 \%, 5 \%$, and $10 \%$ level, respectively. See Table A1 for a description of the variables.

\begin{tabular}{|c|c|c|c|c|c|c|c|c|}
\hline & \multicolumn{2}{|c|}{ Sales/Assets } & \multicolumn{2}{|c|}{ ROA } & \multicolumn{2}{|c|}{ Negative NI } & \multicolumn{2}{|c|}{ KZ-Index } \\
\hline & $\begin{array}{c}\text { OLS } \\
(1)\end{array}$ & $\begin{array}{l}\text { IV } \\
(2) \\
\end{array}$ & $\begin{array}{c}\text { OLS } \\
\text { (3) }\end{array}$ & $\begin{array}{l}\text { IV } \\
(4) \\
\end{array}$ & $\begin{array}{c}\text { OLS } \\
(5)\end{array}$ & $\begin{array}{l}\text { IV } \\
(6) \\
\end{array}$ & $\begin{array}{l}\text { OLS } \\
(7)\end{array}$ & $\begin{array}{l}\text { IV } \\
(8)\end{array}$ \\
\hline ExEGC & $\begin{array}{c}0.191 * * * \\
(0.058)\end{array}$ & $\begin{array}{c}0.310^{* *} \\
(0.157)\end{array}$ & $\begin{array}{c}0.076^{* *} \\
(0.038)\end{array}$ & $\begin{array}{c}0.290 * * * \\
(0.106)\end{array}$ & $\begin{array}{c}-0.162 * * * \\
(0.056)\end{array}$ & $\begin{array}{c}-0.431 * * * \\
(0.164)\end{array}$ & $\begin{array}{l}-0.303^{*} \\
(0.156)\end{array}$ & $\begin{array}{c}-0.737 * * \\
(0.333)\end{array}$ \\
\hline Controls & $\mathrm{Y}$ & $\mathrm{Y}$ & $\mathrm{Y}$ & $\mathrm{Y}$ & $\mathrm{Y}$ & $\mathrm{Y}$ & $\mathrm{Y}$ & $\mathrm{Y}$ \\
\hline Industry FE & Y & Y & Y & Y & Y & $\mathrm{Y}$ & Y & $\mathrm{Y}$ \\
\hline Year FE & $\mathrm{Y}$ & $\mathrm{Y}$ & $\mathrm{Y}$ & $\mathrm{Y}$ & $\mathrm{Y}$ & $\mathrm{Y}$ & $\mathrm{Y}$ & $\mathrm{Y}$ \\
\hline Observations & 272 & 272 & 273 & 273 & 276 & 276 & 270 & 270 \\
\hline Adjusted $\mathrm{R}^{2}$ & 0.702 & 0.696 & 0.480 & 0.392 & 0.419 & 0.350 & 0.164 & 0.119 \\
\hline First-Stage $\mathrm{R}^{2}$ & & 0.197 & & 0.188 & & 0.184 & & 0.201 \\
\hline First Stage F-stat & & 28.002 & & 26.79 & & 29.486 & & 27.606 \\
\hline
\end{tabular}




\title{
ONLINE APPENDIX
}

\section{Disclosure, Firm Growth, and the JOBS Act}

\author{
Anantha Divakaruni ${ }^{*}$ and Howard Jones ${ }^{\dagger}$
}

Appendix A. Supplementary Tables and Figures 1

Appendix B. Impact of the JOBS Act on US equity issuance: International evidence ..........14

Appendix C. Supplementary information on the JOBS Act ...............................................24

Appendix D. Implications of EGC status loss on reporting costs......................................28

Appendix E. Implications of EGC status loss on earnings management ...............................32

\footnotetext{
"University of Bergen; Email: anantha.divakaruni@uib.no

${ }^{\dagger}$ Saïd Business School, University of Oxford; Email: howard.jones@sbs.ox.ac.uk
} 


\section{A. Supplementary Tables and Figures}

Figure A1. Do EGCs manipulate float well in advance of the LAF deadline?

Figure illustrates a test of density discontinuity in the float of EGCs around the vertical cutoff (float $=\$ 700$ million). The running variable float is the market value of common equity held by public investors on the last day six months prior to the second fiscal quarter. The sample comprises firms that went public as EGCs between April 6, 2012 and April 30, 2019. The manipulation test statistic at the top right corner of the plot is based on local polynomial density estimation from Cattaneo et al. (2019). The $p$-value of the test statistic is in the parantheses. A statistically significant discontinuity indicates possible manipulation of the float near the cutoff.

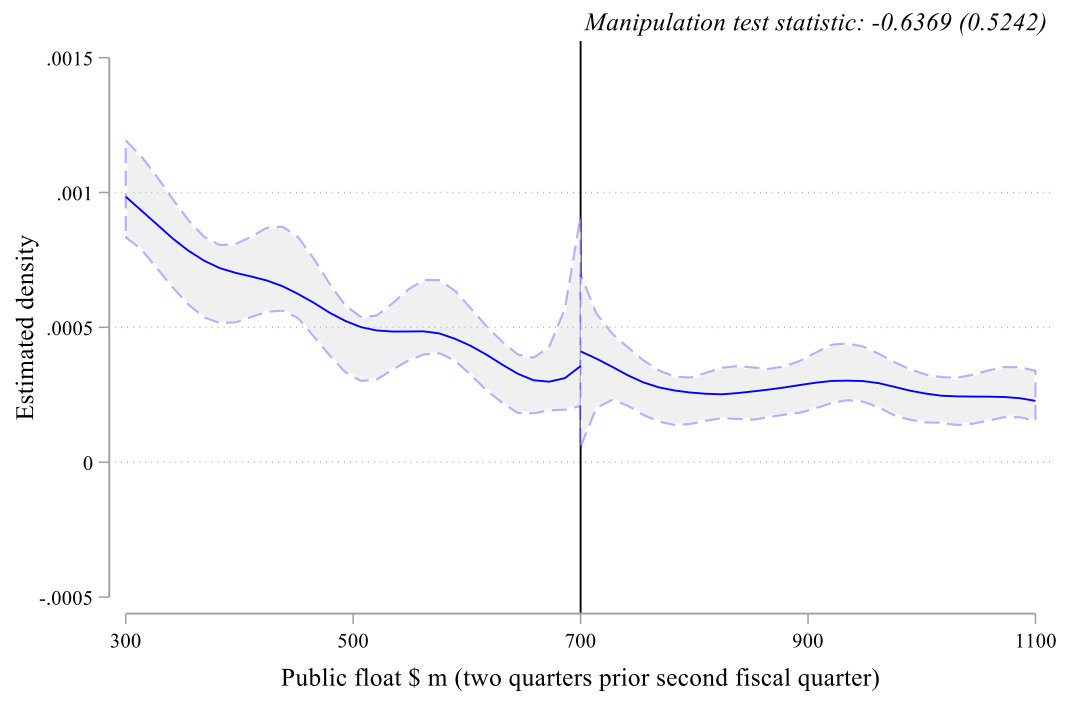

Figure A2. Correlation between float at the end of second fiscal quarter and six months prior among EGC firms

Figure shows a scatter plot and linear prediction line between the float of an EGC at the end of a second fiscal quarter (y-axis) and its float six months prior (x-axis). Float of a firm is the market value of common equity held by public investors. The adjusted $\mathrm{R}^{2}$ of the linear regression is shown at the top right corner.

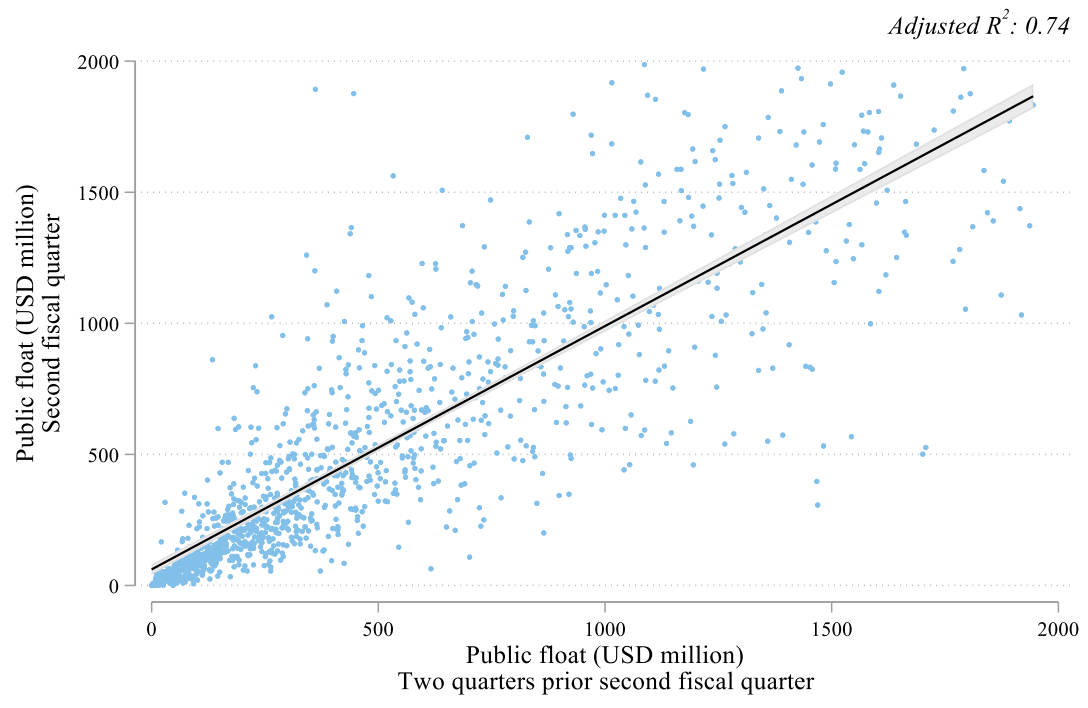


Figure A3. Observable EGC characteristics

Figure shows evidence of smoothness of observable firm characteristics around the LAF treatment threshold (float $=\$ 700$ million) among EGC firms. The observable characteristics considered are listed on top of each plot. The running variable float is the market value of common equity of the sample firm held by public investors and measured on the last day of the second fiscal quarter each year after the IPO. Blue lines represent the fitted prediction line from a local polynomial estimator. Discontinuities in the fitted prediction at the LAF threshold imply that concerned firm characteristic is imbalanced at the cutoff.
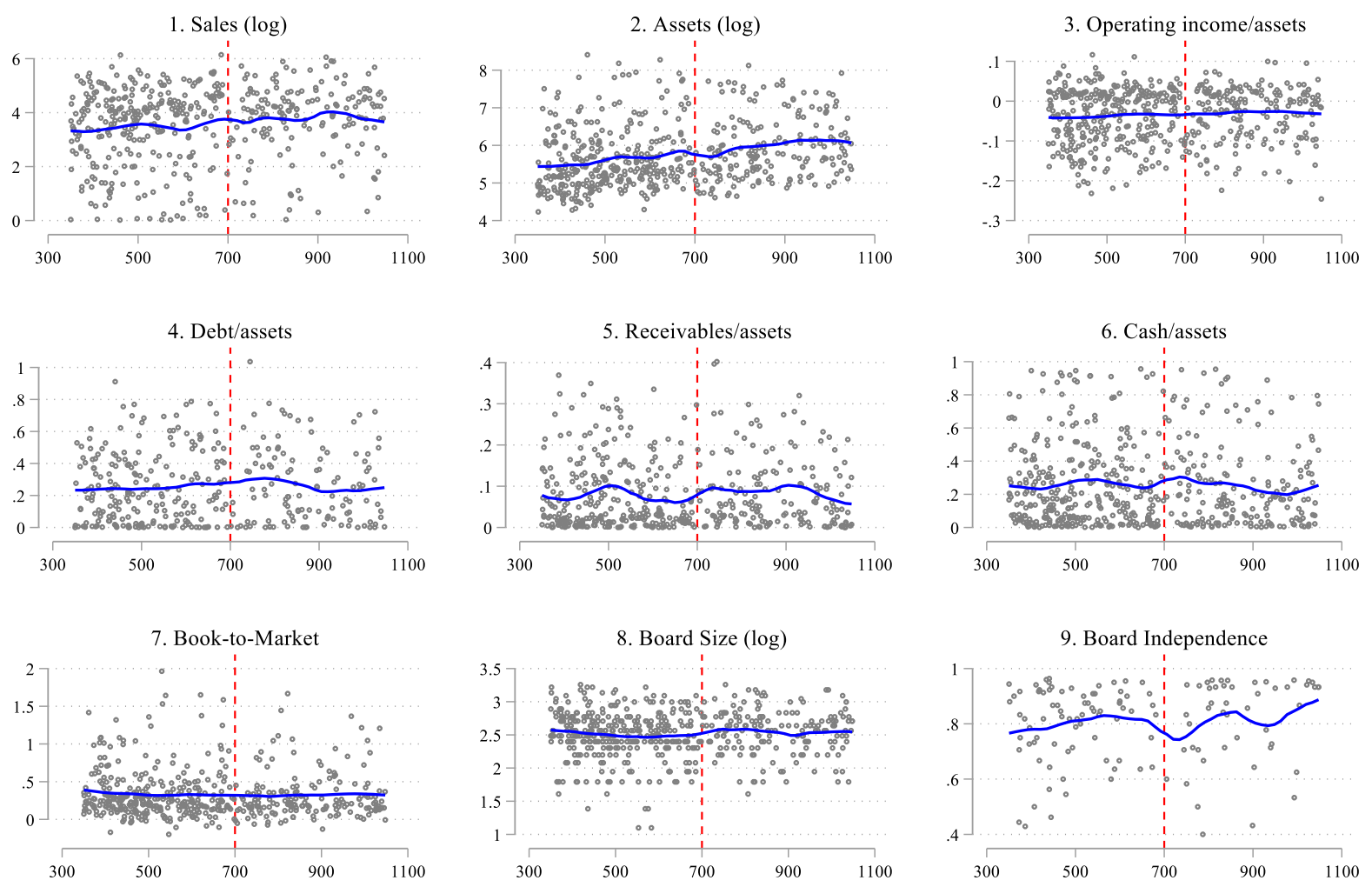
Figure A4. IPO activity around the JOBS Act

Panel (a) shows the number of IPOs filed per quarter between January 1, 2000 and December 31, 2017. The data are obtained from S-1 filings available with the SEC. See Section 2.1 for a description of the sample. $E G C$ refers to emerging growth companies that went public after the passage of Title I of the JOBS Act on April 5, 2012 and chose to avail exemptions from mandatory disclosure under the Act's provisions at the time of filing. See Section 3.1 for a detailed description of the sample construction. Panel (b) presents bar charts of the number of IPOs filed by EGC firms (left plot) and NonEGC firms (right plot). Firms in each chart are split according to their perceived growth opportunities at the time of their IPO into high-growth (Tobin's $q>1$ ) and low-growth (Tobin's $q \leq 1$ ) categories. NonEGC refers to firms that went public before the JOBS Act (January 1, 2000-April 4, 2012) and thus do not quality for EGC treatment during their IPO.

\section{a) IPOs filed per quarter}

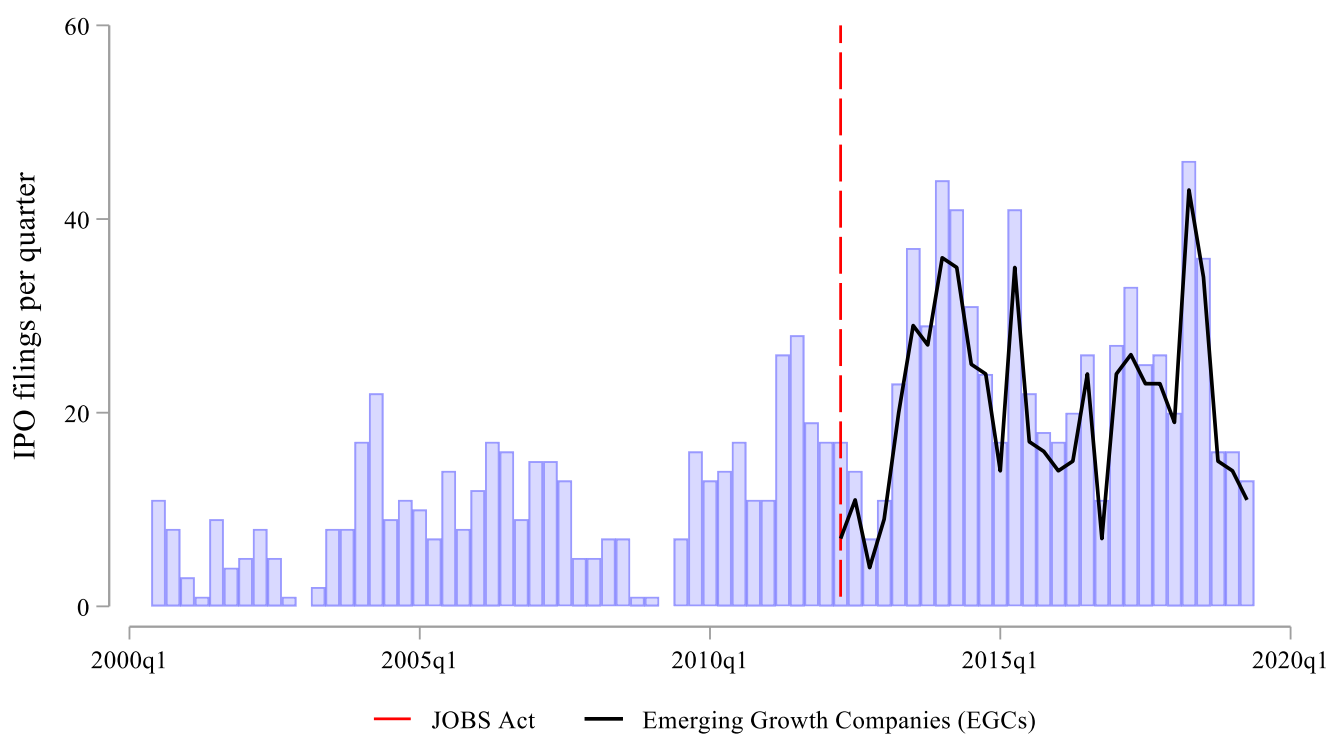

b) IPOs by firm growth opportunities (Tobin's Q)

EGC firms (Post-JOBS)

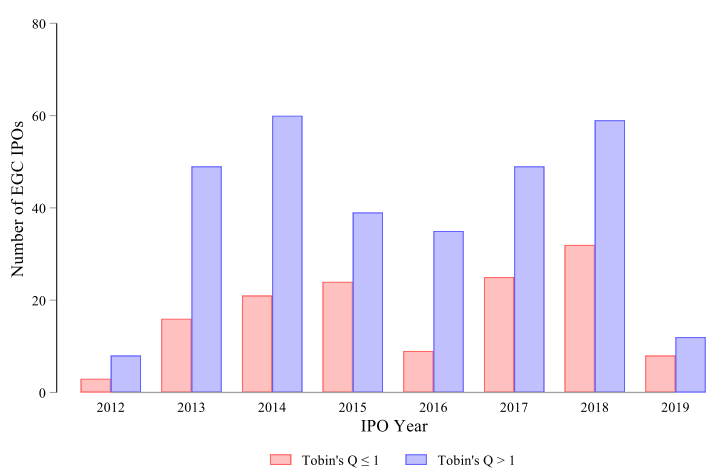

NonEGC firms (Pre-JOBS)

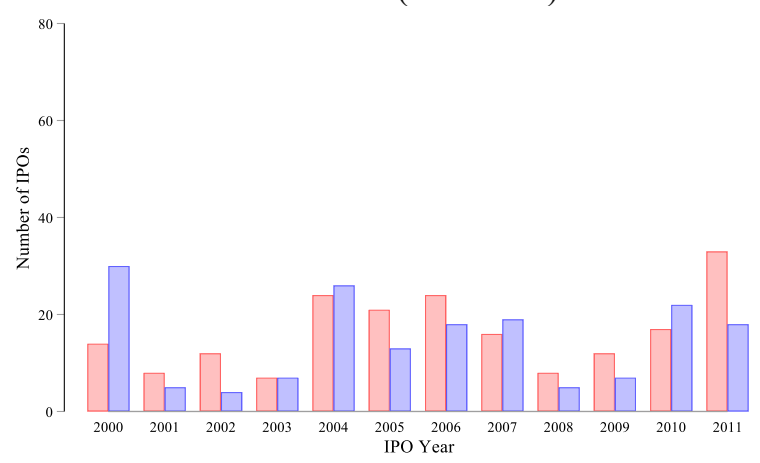

$\square$ Tobin's $Q \leq 1 \quad \square$ Tobin's Q>1 
Figure A5. NonEGC Fundraising by Listing Age

The sample for the below plots comprises NonEGC firms that went public before the JOBS Act (January 1, 2000-April 4, 2012) and thus do not quality for EGC treatment during their IPO. The Panel (a) presents the fraction of NonEGC firms raising equity during the first ten years after their IPO. The left-hand plot covers all firms in the sample while the right-hand plot splits the firms according to their perceived growth opportunities each year into high-growth (Tobin's $q>1$ ) and low-growth (Tobin's $q \leq 1$ ) categories. See Section 3.1 for a description of the sample construction. Panel (b) presents the fraction of NonEGC firms raising debt during the first ten years after their IPO.

a) Fraction of NonEGC firms raising equity
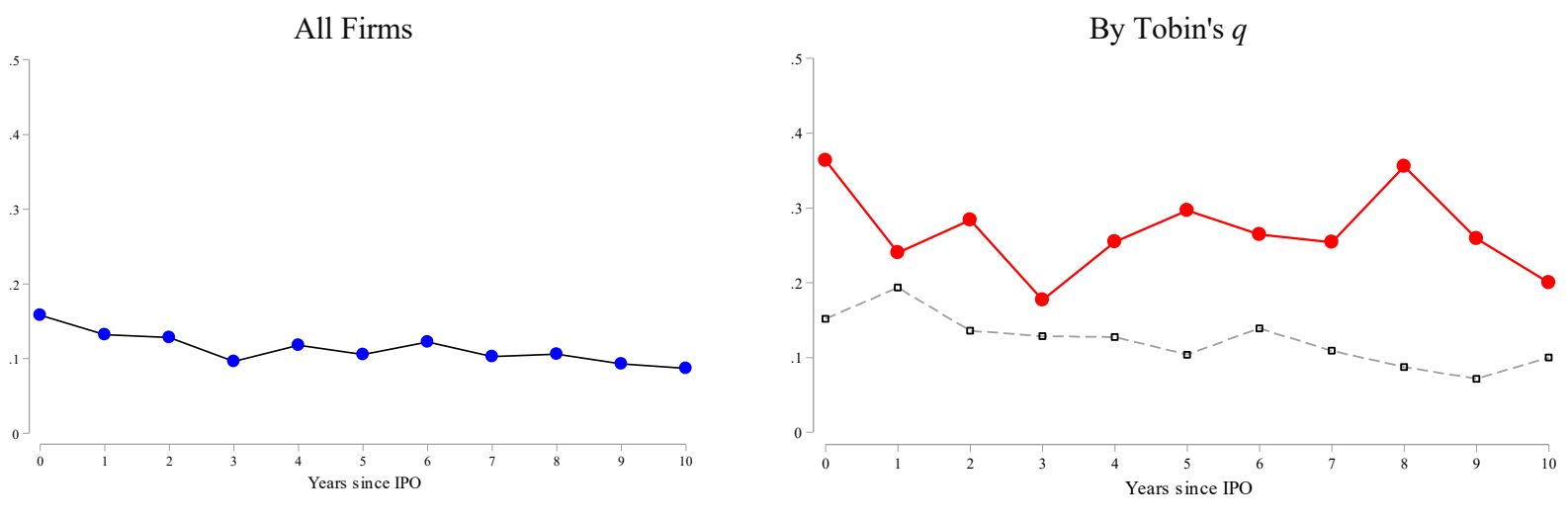

b) Fraction of NonEGC firms raising debt

All Firms

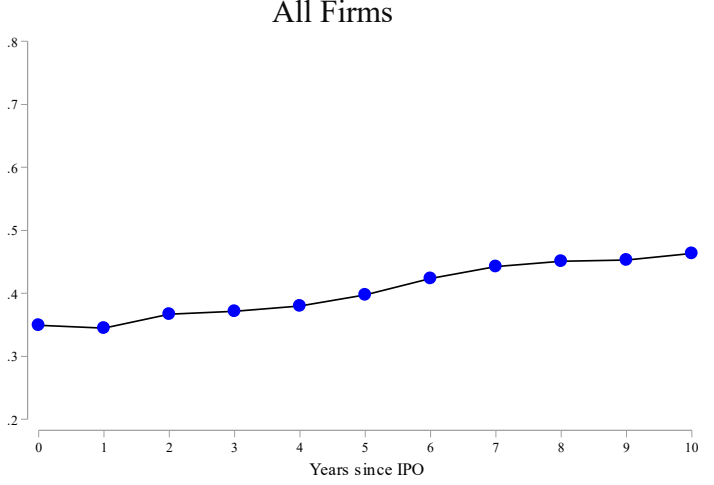

By Tobin's $q$

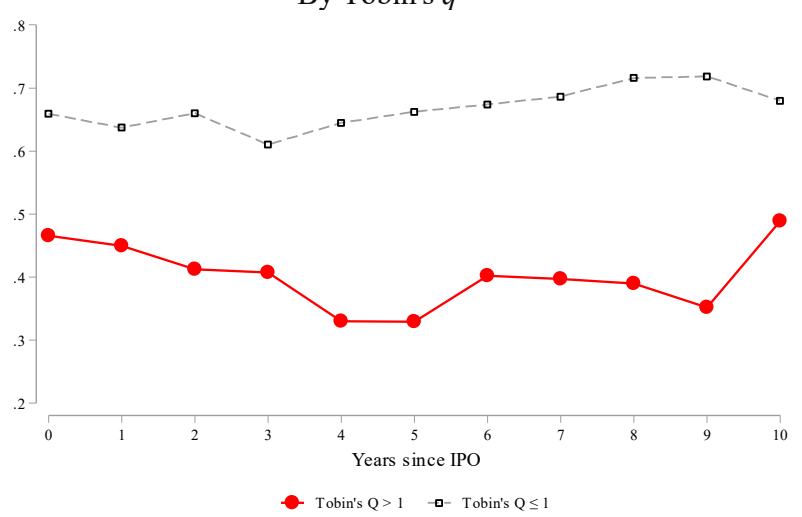


Appendix: Variable definitions

The primary data sources for computing the variables are Capital IQ, Compustat, and BoardEx. Italicized names in brackets refer to Compustat data items.

\begin{tabular}{|c|c|c|}
\hline Variable & Unit & Description \\
\hline \multicolumn{3}{|l|}{ JOBS Act } \\
\hline Post JOBS & $0 / 1$ & $\begin{array}{l}\text { Dummy variable equal to one for equity offers in the period following Title I of } \\
\text { the JOBS Act (between April 6, } 2012 \text { and April 30, 2019), and zero for equity } \\
\text { offers in the period before Title I (between January 1,2000 and April 4, 2012). }\end{array}$ \\
\hline \multicolumn{3}{|l|}{ Fundraising } \\
\hline New Equity & \$ mil. & $\begin{array}{l}\text { Dollar value of common stock issued by the firm via seasoned public offers (SPOs) } \\
\text { during a fiscal year. Data is from Capital IQ. }\end{array}$ \\
\hline Purchased Equity & \$ mil. & Funds used to repurchase common stock (PRSTKCC). \\
\hline Net Equity Issuance & \$ mil. & Difference between New Equity and Purchased Equity. \\
\hline Direct Equity Costs & Ratio & $\begin{array}{l}\text { Underwriting fees charged for an SPO scaled by offer proceeds. Data from Capital } \\
\text { IQ. }\end{array}$ \\
\hline Indirect Equity Costs & Ratio & $\begin{array}{l}\text { Minus one times the difference between previous day's closing price and the SPO } \\
\text { offer price, scaled by the previous day's closing price. Data from Capital IQ. This } \\
\text { variable is equivalent to the "underpricing" measure used in extant literature. }\end{array}$ \\
\hline New Debt & \$ mil. & $\begin{array}{l}\text { Total annual long-term debt issued (DLTIS), and covers bonds, notes, lease } \\
\text { obligations, debt reclassifications, and acquisition loans. }\end{array}$ \\
\hline Debt Costs & Ratio & $\begin{array}{l}\text { Annual interest expense (XINT) divided by long-term debt (DLTT) plus debt in } \\
\text { current liabilities }(D L C) \text {. }\end{array}$ \\
\hline
\end{tabular}

Internal Investments

Firm characteristics

$0 / 1$

Dummy equal to one if the firm went public as an "Emerging Growth Company" (EGC) under provisions of Title I of the JOBS Act, and zero otherwise. Firms can qualify for EGC treatment if their annual gross revenue is below $\$ 1$ billion in the most recent fiscal year and if they are going public for the first time after December 9, 2011. These firms can remain qualified for EGC treatment when conducting secondary public equity offers (SPOs) for up to five years after the IPO if their annual gross revenue is below $\$ 1$ billion ( $\$ 1.07$ billion since April 1, 2017), no more than $\$ 1$ billion was issued in non-convertible debt in the previous three years, and the float is below $\$ 700$ million in the most recent second fiscal quarter.

ExEGC

$0 / 1$

NonEGC

$0 / 1$

Float

Total Assets

Total Sales

Net Income (NI)

Change in Net Income

Negative NI

Cash flow from

Operations

Employees

Age

Listing Age
Dummy equal to one if the float of an EGC exceeds $\$ 700$ million on the last day of the most recent second fiscal quarter, and zero otherwise. An EGC whose float exceeds the $\$ 700$ million limit will become a "large accelerated filer" (LAF) and will be subject to mandatory disclosure requirements. An EGC that ceases to remain exempt due to the LAF rule cannot be reclassified back.

Dummy equal to one if the firm went public before the JOBS Act went into effect (i.e., between April 6, 2012 and April 30, 2019), and thus would not have qualified for disclosure exemptions under the Act.

$\$$ mil. Market value of the portion of common equity held by public investors.

$\$$ mil. Total assets $(A T)$ reported in the most recent fiscal year.

$\$$ mil.

$\$$ mil.

Ratio

$0 / 1$

\$ mil.

Integer

Integer

Integer
Total revenue (SALE) reported in the most recent fiscal year.

Sales minus operating expenses and losses $(N I)$.

Difference in net income (NI) between current and previous fiscal year.

Dummy equal to one if the net income is below zero.

Operating cash flow (OANCF) minus extraordinary items (XIDOC).

Total number of employees in the most recent fiscal year (EMP).

Age of the firm (in years) since the data of incorporation.

Number of years since the firm went public through an IPO. 


$\begin{array}{ll}\text { Debt to Total Assets } & \text { Ratio } \\ \text { Cash to Total Assets } & \text { Ratio } \\ \text { Return on Assets (ROA) } & \text { Ratio } \\ \text { Capex } & \text { \$ mil. } \\ \text { PPE } & \text { mil. } \\ \text { R\&D } & \text { \$ mil. } \\ \text { Tobin's } q & \text { Ratio }\end{array}$

Book to Market

Ratio

KZ-Index

Board size

Board independence

Acquisition

Value of Acquisitions

All Cash Acquisitions

Audit fees

Accruals

Integer

Ratio

$0 / 1$

\$ mil.

$0 / 1$

\$ mil.

Ratio
Ratio of long-term debt (DLTT) to total assets $(A T)$.

Ratio of cash and cash equivalents (CHE) to total assets ( $A T)$.

Operating income before depreciation $(O I B D P)$ scaled by lagged total assets $(A T)$.

Capital expenses $(C A P X)$ net of depreciation and amortization charges $(D P)$.

Property, plan, and equipment less depreciation used in production (PPENT).

Research and development costs (XRD).

Ratio of the market value of assets divided by book value of assets. We follow Kaplan and Zingales (1997) and estimate this ratio firm $i$ in year $t$,

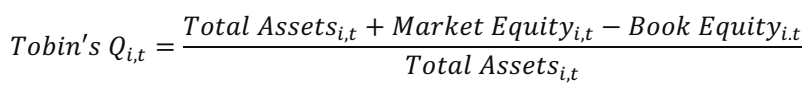

where total assets is as reported (AT), market equity is year-end closing price $(P R C C C)$ times common shares outstanding $(C S H O)$, book equity is measured as stockholders' equity $(S E Q)$ plus deferred taxes $(T X D B)$ plus investment tax credits (ITCB) minus preferred stock (PSTKRV or PSTKL or PSTK).

Total common equity $(C E Q)$ plus deferred tax and investment tax credits (TXDITC) minus preferred stock (PSTKRV or PSTKL or PSTK) divided by market value of equity $(P R C C C \times C S H O)$ at the end of fiscal year.

Measure of the firm's financial constraints based on Kaplan and Zingales (1997). We follow Lamont, Polk and Saaá-Requejo (2001) and compute this index as $-1.0001909 \times[(I B+D P) / P P E N T T-1]+0.2826389 \times[(S I Z E) / A T]+3.139193 \times$ $[(D L T T+D L C) /(D L T T+D L C+S E Q)]-39.3678 \times[(D V C+D V P) / P P E N T T-1]-$ $1.314759 \times[C H E / A T T-1]$. SIZE is logarithm of the market value of assets at beginning of the year and is $A T-C E Q+(C S H O \times P R C C F)-T X T B$.

Number of members on the company's board. Data from BoardEx.

Percentage of independent members on the board. Data from BoardEx.

Dummy equal to one if the firm made at least one acquisition in a given year.

Dollar value of acquisitions made by firm in a given year.

Dummy equal to one if all acquisitions made by firm in a given year are paid for entirely in cash.

Total audit and audit-related fees paid per year. Data from Audit Analytics.

Non-cash portion of earnings, measured as income before extraordinary items $(I B C)$ minus cash flow from operations $(O A N C F)$ plus extraordinary items $(X I D O C)$, scaled by lagged assets $(A T)$. Following Iliev (2010), values exceeding $\pm 100 \%$ are censored.

Big4 Auditor $\quad 0 / 1 \quad$ Dummy equal to one if the firm used one of the top four auditing firms in the world (PricewaterhouseCoopers, Deloitte and Touche, Ernst and Young, KPMG). Dummy equal to one if the CEO is also chairman of the board.

Dual CEO

Public market/macroeconomic characteristics

\begin{tabular}{|c|c|c|}
\hline $\begin{array}{l}\text { Stock Market Return } \\
\text { Hot SPO Market }\end{array}$ & Ratio & $\begin{array}{l}\text { Monthly compounded stock market return in the most recent twelve months. } \\
\text { Dummy equal to one if the number of SPOs in a given year is in the top quartile } \\
\text { of the distribution of SPO activity per annum. } \\
\text { the highest (lowest) quartile in the number of IPOs per Month. }\end{array}$ \\
\hline GDP growth & Ratio & The year-on-year growth rate in the gross domestic product of a given country. \\
\hline
\end{tabular}


Table A1. Summary Statistics: EGC (at IPO) versus NonEGC firms

The sample comprises US firms that went public between January 1, 2000 and April 30, 2019. See Section 3.1 for a description of the sample construction. Panel A reports summary statistics on firms that went public as an "Emerging Growth Company" (EGC) under the provisions of Title I of the JOBS Act. Panel B comprises NonEGC firms that went public before the JOBS Act (January 1, 2000-April 4, 2012) and thus do not quality for EGC treatment during their IPO. Wherever applicable, total assets (TA) in the denominator are lagged by one year with respect to the numerator. See Table A1 for a description of the variables listed below. $* * *, * *$, and $*$ denote significance at the $1 \%, 5 \%$, and $10 \%$ level, respectively.

\begin{tabular}{|c|c|c|c|c|c|c|c|}
\hline & \multicolumn{3}{|c|}{ Panel A: EGC firms (at IPO) } & \multicolumn{3}{|c|}{ Panel B: NonEGC firms } & \multirow{2}{*}{$\begin{array}{c}\text { Difference } \\
\text { in means }\end{array}$} \\
\hline & Mean & $\mathrm{SD}$ & Median & Mean & $\mathrm{SD}$ & Median & \\
\hline Market Capitalization (second fiscal quarter) & 1086.04 & 2162.07 & 450.30 & 1285.13 & 4198.82 & 420.60 & $199.09 * * *$ \\
\hline Age (years) & 13.10 & 14.98 & 9.00 & 22.20 & 20.07 & 17.00 & $9.10 * * *$ \\
\hline Total Assets (\$m) & 573.85 & 1128.03 & 206.91 & 723.24 & 1284.35 & 285.36 & $149.39 * * *$ \\
\hline Total Debt/TA & 0.41 & 0.41 & 0.34 & 0.41 & 0.43 & 0.33 & 0.00 \\
\hline LT Debt/TA & 0.20 & 0.32 & 0.18 & 0.24 & 0.37 & 0.21 & $0.04 * *$ \\
\hline ST Debt/TA & 0.03 & 0.09 & 0.01 & 0.04 & 0.44 & 0.01 & 0.01 \\
\hline Tobin's Q & 1.56 & 1.01 & 1.30 & 1.25 & 0.87 & 0.96 & $-0.31 * * *$ \\
\hline Capex/TA & 0.05 & 0.07 & 0.02 & 0.05 & 0.07 & 0.02 & 0.00 \\
\hline $\mathrm{R} \& \mathrm{D} / \mathrm{TA}$ & 0.07 & 0.06 & 0.06 & 0.05 & 0.07 & 0.03 & $-0.02 * * *$ \\
\hline $\mathrm{Cash} / \mathrm{TA}$ & 0.30 & 0.29 & 0.21 & 0.20 & 0.21 & 0.13 & $-0.10 * * *$ \\
\hline Board Size & 13.23 & 4.86 & 13.00 & 13.63 & 6.05 & 13.00 & $0.39 * * *$ \\
\hline Board Independence & 0.95 & 0.12 & 1.00 & 0.96 & 0.10 & 1.00 & $0.01 * *$ \\
\hline Number of SPOs during fiscal year & 0.43 & 0.69 & 0.00 & 0.14 & 0.40 & 0.00 & $-0.29 * * *$ \\
\hline SPO proceeds during fiscal year $(\$ \mathrm{~m})$ & 51.26 & 135.04 & 0.00 & 13.53 & 56.25 & 0.00 & $-37.73 * * *$ \\
\hline LT debt issued in fiscal year $(\$ \mathrm{~m})$ & 180.22 & 515.78 & 0.00 & 220.97 & 592.38 & 0.00 & $40.75 * * *$ \\
\hline LT debt issued in fiscal year/TA & 0.20 & 0.40 & 0.00 & 0.21 & 0.40 & 0.00 & 0.01 \\
\hline 1-year Capex growth & 0.06 & 0.69 & -0.00 & 0.04 & 0.64 & -0.01 & -0.02 \\
\hline 1-year R\&D growth & 0.22 & 0.52 & 0.20 & 0.09 & 0.46 & 0.09 & $-0.13 * * *$ \\
\hline Employees & 2842.91 & 5358.17 & 985.00 & 2585.51 & 5239.94 & 749.00 & -257.40 \\
\hline 1-year Employee growth & -0.03 & 0.17 & 0.00 & -0.03 & 0.17 & 0.00 & 0.00 \\
\hline Number of acquisitions during fiscal year & 1.06 & 0.23 & 1.00 & 1.11 & 0.33 & 1.00 & 0.05 \\
\hline Value of acquisitions during fiscal year ( $\$ \mathrm{~m})$ & 262.41 & 697.16 & 43.13 & 151.71 & 493.85 & 40.70 & -110.70 \\
\hline All cash acquisitions $(\%)$ & 0.76 & 0.43 & 1.00 & 0.77 & 0.42 & 1.00 & 0.01 \\
\hline Observations & & 1968 & & & 6647 & & \\
\hline
\end{tabular}


Table A2: Do EGC firms manipulate their float?

Table presents probit estimates of the likelihood that an EGC firm will repurchase shares to manipulate its float and attempt to evade compliance with the "Large Accelerated Filer" (LAF) regulation. An EGC will lose its exemptions and become a LAF if its float exceeds $\$ 700$ million on the last day of the most recent second fiscal quarter. The dependent variable in panel $\mathrm{A}$ is a dummy equal to one if the EGC firm initiates a share buyback program during the six months preceding the last day of the second fiscal quarter. The dependent variable in panel B is a dummy equal to one if the EGC firm initiates a share buyback program during the six months following the last day of the second fiscal quarter. Float $\geq 700 \mathrm{~m}$ is a dummy equal to one if the firm's float is greater than or equal to $\$ 700$ million exactly (i) six months before the end of most recent second fiscal quarter (Panel A), or, (ii) at the end of most recent second fiscal quarter (Panel B). We use three different bandwidths $h \in$ (\$250 million, \$300 million, \$350million) around the LAF cutoff. Standard errors are clustered at the firm level and reported in parentheses. $* * *, * *$, and $*$ denote significance at the $1 \%, 5 \%$, and $10 \%$ level, respectively.

\begin{tabular}{|c|c|c|c|c|c|c|}
\hline & \multicolumn{6}{|c|}{ Dependent Variable: Likelihood of Share Buybacks } \\
\hline & \multicolumn{3}{|c|}{$\begin{array}{l}\text { Panel A: } 0-6 \text { months } \\
\text { before end of } 2^{\text {nd }} \text { fiscal quarter }\end{array}$} & \multicolumn{3}{|c|}{$\begin{array}{c}\text { Panel B: } 0-6 \text { months } \\
\text { after end of } 2^{\text {nd }} \text { fiscal quarter }\end{array}$} \\
\hline & $\begin{array}{c}h=\$ 250 m \\
(1)\end{array}$ & $\begin{array}{c}h=\$ 300 m \\
(2)\end{array}$ & $\begin{array}{c}h=\$ 350 m \\
(3)\end{array}$ & $\begin{array}{c}h=\$ 250 m \\
(4)\end{array}$ & $\begin{array}{c}h=\$ 300 m \\
(5)\end{array}$ & $\begin{array}{c}h=\$ 350 m \\
(6)\end{array}$ \\
\hline Float $\geq 700 \mathrm{~m}$ & $\begin{array}{c}0.683 * * \\
(0.312)\end{array}$ & $\begin{array}{l}0.730 * * * \\
(0.256)\end{array}$ & $\begin{array}{c}0.786 * * * \\
(0.233)\end{array}$ & $\begin{array}{c}0.346 \\
(0.413)\end{array}$ & $\begin{array}{c}0.168 \\
(0.339)\end{array}$ & $\begin{array}{c}0.321 \\
(0.321)\end{array}$ \\
\hline $\log (\text { Assets })_{t-1}$ & $\begin{array}{l}-0.302 \\
(0.303)\end{array}$ & $\begin{array}{l}-0.086 \\
(0.287)\end{array}$ & $\begin{array}{c}0.064 \\
(0.265)\end{array}$ & $\begin{array}{l}-0.024 \\
(0.277)\end{array}$ & $\begin{array}{l}0.003 \\
(0.274)\end{array}$ & $\begin{array}{c}0.007 \\
(0.267)\end{array}$ \\
\hline $\log (\text { Employees })_{\mathrm{t}-1}$ & $\begin{array}{l}-0.099 \\
(0.063)\end{array}$ & $\begin{array}{l}-0.044 \\
(0.054)\end{array}$ & $\begin{array}{l}-0.030 \\
(0.049)\end{array}$ & $\begin{array}{l}-0.097 \\
(0.060)\end{array}$ & $\begin{array}{l}-0.060 \\
(0.050)\end{array}$ & $\begin{array}{l}-0.044 \\
(0.046)\end{array}$ \\
\hline Debt to Assetst 1 & $\begin{array}{c}0.091 \\
(0.749)\end{array}$ & $\begin{array}{c}0.094 \\
(0.685)\end{array}$ & $\begin{array}{l}-0.315 \\
(0.685)\end{array}$ & $\begin{array}{l}-0.037 \\
(0.683)\end{array}$ & $\begin{array}{c}0.251 \\
(0.747)\end{array}$ & $\begin{array}{c}0.124 \\
(0.706)\end{array}$ \\
\hline Cash to Assets $t_{t-1}$ & $\begin{array}{c}-3.430 * * * \\
(1.047)\end{array}$ & $\begin{array}{c}-1.860 * * \\
(0.801)\end{array}$ & $\begin{array}{c}-1.682 * * \\
(0.734)\end{array}$ & $\begin{array}{c}0.564 \\
(0.865)\end{array}$ & $\begin{array}{c}0.854 \\
(0.813)\end{array}$ & $\begin{array}{c}1.004 \\
(0.810)\end{array}$ \\
\hline Capex to Assets $\mathrm{t}_{\mathrm{t}-1}$ & $\begin{array}{c}3.717 \\
(2.722)\end{array}$ & $\begin{array}{c}3.436 \\
(2.747)\end{array}$ & $\begin{array}{c}4.010 \\
(2.653)\end{array}$ & $\begin{array}{c}0.073 \\
(2.309)\end{array}$ & $\begin{array}{l}-0.010 \\
(2.225)\end{array}$ & $\begin{array}{c}1.448 \\
(1.999)\end{array}$ \\
\hline R\&D to Assets $_{t-1}$ & $\begin{array}{c}0.988 \\
(1.869)\end{array}$ & $\begin{array}{c}0.939 \\
(1.557)\end{array}$ & $\begin{array}{c}0.930 \\
(1.257)\end{array}$ & $\begin{array}{l}3.411^{*} \\
(2.044)\end{array}$ & $\begin{array}{c}2.555 \\
(1.888)\end{array}$ & $\begin{array}{l}1.960 \\
(1.522)\end{array}$ \\
\hline Tobin's $Q_{t-1}$ & $\begin{array}{c}0.041 \\
(0.099)\end{array}$ & $\begin{array}{c}0.001 \\
(0.091)\end{array}$ & $\begin{array}{l}-0.012 \\
(0.087)\end{array}$ & $\begin{array}{c}0.011 \\
(0.095)\end{array}$ & $\begin{array}{l}-0.021 \\
(0.094)\end{array}$ & $\begin{array}{l}-0.009 \\
(0.086)\end{array}$ \\
\hline $\log (\text { Age })_{t-1}$ & $\begin{array}{c}0.128 \\
(0.164)\end{array}$ & $\begin{array}{c}0.142 \\
(0.154)\end{array}$ & $\begin{array}{c}0.111 \\
(0.118)\end{array}$ & $\begin{array}{c}0.138 \\
(0.101)\end{array}$ & $\begin{array}{c}0.093 \\
(0.094)\end{array}$ & $\begin{array}{c}0.097 \\
(0.089)\end{array}$ \\
\hline $\log (\text { Board Size })_{\mathrm{t}-1}$ & $\begin{array}{c}0.683 \\
(0.702)\end{array}$ & $\begin{array}{c}0.526 \\
(0.577)\end{array}$ & $\begin{array}{c}0.421 \\
(0.482)\end{array}$ & $\begin{array}{l}0.883^{*} \\
(0.515)\end{array}$ & $\begin{array}{c}0.644 \\
(0.518)\end{array}$ & $\begin{array}{c}0.626 \\
(0.478)\end{array}$ \\
\hline Board Independence $_{t-1}$ & $\begin{array}{c}6.244 * * \\
(2.509)\end{array}$ & $\begin{array}{c}5.881 * * * \\
(1.910)\end{array}$ & $\begin{array}{c}3.664 * * \\
(1.599)\end{array}$ & $\begin{array}{l}4.293 * * \\
(1.869)\end{array}$ & $\begin{array}{c}4.507 * * * \\
(1.450)\end{array}$ & $\begin{array}{l}3.444 * * \\
(1.390)\end{array}$ \\
\hline Stock Market Return $\mathrm{t}_{-1}$ & $\begin{array}{c}0.612 * * * \\
(0.196)\end{array}$ & $\begin{array}{c}0.525^{* * *} \\
(0.188)\end{array}$ & $\begin{array}{c}0.396 * * * \\
(0.136)\end{array}$ & $\begin{array}{c}0.120 \\
(0.106)\end{array}$ & $\begin{array}{c}0.168 * * \\
(0.075)\end{array}$ & $\begin{array}{l}0.143^{*} \\
(0.074)\end{array}$ \\
\hline Hot SPO Market & $\begin{array}{l}-0.599^{*} \\
(0.312)\end{array}$ & $\begin{array}{l}-0.352 \\
(0.248)\end{array}$ & $\begin{array}{c}-0.379^{*} \\
(0.205)\end{array}$ & $\begin{array}{c}-1.313^{* * * *} \\
(0.456)\end{array}$ & $\begin{array}{c}-0.823^{*} \\
(0.486)\end{array}$ & $\begin{array}{l}-0.781 \\
(0.530)\end{array}$ \\
\hline Constant & $\begin{array}{c}-8.704 * * \\
(3.767) \\
\end{array}$ & $\begin{array}{c}-9.353 * * * \\
(3.330)\end{array}$ & $\begin{array}{c}-7.192 * * \\
(2.874) \\
\end{array}$ & $\begin{array}{l}-4.391 \\
(2.865) \\
\end{array}$ & $\begin{array}{c}-5.261 * * \\
(2.465)\end{array}$ & $\begin{array}{l}-4.574^{*} \\
(2.368)\end{array}$ \\
\hline Industry-Year FE & $\mathrm{Y}$ & $\mathrm{Y}$ & $\mathrm{Y}$ & $\mathrm{Y}$ & $\mathrm{Y}$ & $\mathrm{Y}$ \\
\hline $\begin{array}{l}\mathrm{N} \\
\text { Pseudo } \mathrm{R}^{2}\end{array}$ & $\begin{array}{c}170 \\
0.422\end{array}$ & $\begin{array}{c}220 \\
0.360\end{array}$ & $\begin{array}{c}287 \\
0.346\end{array}$ & $\begin{array}{c}133 \\
0.247\end{array}$ & $\begin{array}{c}170 \\
0.232\end{array}$ & $\begin{array}{c}204 \\
0.220\end{array}$ \\
\hline
\end{tabular}


Table A3. Summary Statistics: Equity and Debt Issuance

Tables below present various summary statistics of equity and debt issued by EGC firms in our sample. The sample comprises firms that went public as an "Emerging Growth Company" (EGC) between April 6, 2012 and April 30, 2019. See Section 3.1 for a detailed description of the sample construction. $E G C$ refers to the firms that have float below $\$ 700$ million and thus remain exempt from mandatory disclosure under Title I of the JOBS Act. ExEGC is a dummy equal to one for firms that have a float above $\$ 700$ million and are thus subject to mandatory disclosure under the "Large Accelerated Filer" (LAF) regulation. Equity issuance (New Equity) is measured as the dollar value of common stock issued by the firm via seasoned public offers (SPOs) during a fiscal year. Data on SPOs is collected from Capital IQ and includes only offers that involve the sale of new primary stock independent of existing shareholders. In part (c) of panel A, summary statistics are reported at the transactional level per SPO. Debt issuance (New Debt) by the firm each year is the total annual long-term debt issued, and covers bonds, notes, lease obligations, debt reclassifications, and acquisition loans. This variable is computed from Compustat data item DLTIS. See Table A1 for a detailed description of the variables.

Panel A: New Equity

a) Top 15 States

\begin{tabular}{lcccc}
\hline State & \# SPO & \% SPO & $\begin{array}{c}\text { SPO amount } \\
\text { issued }(\$ \mathrm{~m})\end{array}$ & $\begin{array}{c}\text { \% SPO amount } \\
\text { issued }\end{array}$ \\
\hline California & 313 & 27.75 & 34669.6 & 22.24 \\
Texas & 152 & 13.48 & 30246.75 & 19.4 \\
Massachusetts & 179 & 15.87 & 18575.71 & 11.91 \\
North Carolina & 58 & 5.14 & 9450.88 & 6.06 \\
New York & 51 & 4.52 & 7725.06 & 4.95 \\
Colorado & 30 & 2.66 & 7600.2 & 4.87 \\
Pennsylvania & 59 & 5.23 & 7318.58 & 4.69 \\
Ohio & 16 & 1.42 & 5262.82 & 3.38 \\
Alabama & 15 & 1.33 & 3674.73 & 1.36 \\
Washington & 23 & 2.04 & 3095.29 & 1.84 \\
Maryland & 28 & 2.48 & 2874.13 & 1.79 \\
New Jersey & 37 & 3.28 & 2789.23 & 1.58 \\
Virginia & 19 & 1.68 & 2455.87 & 1.49 \\
Illinois & 12 & 1.06 & 2326.12 & 1.41 \\
Kansas & 11 & 0.98 & 2194.92 & \\
\hline
\end{tabular}

b) Top 15 Industries

\begin{tabular}{|c|c|c|c|c|c|}
\hline $\begin{array}{c}\text { SIC } \\
\text { (2-digit) }\end{array}$ & Industry & \# SPO & $\%$ SPO & $\begin{array}{l}\text { SPO amount } \\
\text { issued }(\$ \mathrm{~m})\end{array}$ & $\begin{array}{c}\% \text { SPO } \\
\text { amount issued }\end{array}$ \\
\hline 28 & Chemicals and Allied Products & 619 & 54.88 & 53244.24 & 34.15 \\
\hline 73 & Business Services & 111 & 9.84 & 22833.42 & 14.64 \\
\hline 13 & Oil and Gas Extraction & 57 & 5.05 & 18622.7 & 11.94 \\
\hline 49 & Electric, Gas and Sanitary Services & 40 & 3.55 & 9771.65 & 6.27 \\
\hline 46 & Pipelines, Except Natural Gas & 21 & 1.86 & 6999.35 & 4.49 \\
\hline 87 & Engineering, Accounting, and Management Services & 17 & 1.51 & 5154.59 & 3.31 \\
\hline 14 & Mining and Quarrying of Nonmetallic Minerals & 18 & 1.6 & 3910.52 & 2.51 \\
\hline 35 & Industrial Machinery and Computer Equipment & 14 & 1.24 & 3716.83 & 2.38 \\
\hline 38 & Measuring, Photographic, Medical, \& Optical Goods & 53 & 4.7 & 3669.93 & 2.35 \\
\hline 36 & Electronic \& Other Electrical Equipment \& Components & 31 & 2.75 & 3532.73 & 2.27 \\
\hline 83 & Social Services & 12 & 1.06 & 3278.05 & 2.1 \\
\hline 58 & Eating and Drinking Places & 17 & 1.51 & 2897.41 & 1.86 \\
\hline 80 & Health Services & 14 & 1.24 & 2436.82 & 1.56 \\
\hline 67 & Holding and Other Investment Offices & 9 & 0.8 & 2322.29 & 1.49 \\
\hline 79 & Amusement and Recreation Services & 9 & 0.8 & 2187.57 & 1.4 \\
\hline
\end{tabular}


c) Characteristics of Equity Issuance (SPO)

\begin{tabular}{lcccccccccc}
\hline EGC & Min & $10 \mathrm{pc}$ & $25 \mathrm{pc}$ & $50 \mathrm{pc}$ & Mean & $75 \mathrm{pc}$ & $90 \mathrm{pc}$ & Max & SD & Obs \\
\hline Offer (\$m) & 5 & 14.1 & 38 & 78.78 & 115.83 & 148.56 & 259.04 & 1005.67 & 123.02 & 701 \\
Direct Equity Costs (\% offer) & 0 & 0 & 0 & 0 & 2.71 & 0 & 14.8 & 29.75 & 6.84 & 661 \\
Indirect Equity Costs (\% offer) & -42.86 & -0.83 & 0 & 5.85 & 7.72 & 12.77 & 21.43 & 49.69 & 10.49 & 647 \\
\hline & & & & & & & & & & \\
\hline ExEGC & Min & $10 \mathrm{pc}$ & $25 \mathrm{pc}$ & $50 \mathrm{pc}$ & Mean & $75 \mathrm{pc}$ & $90 \mathrm{pc}$ & Max & SD & Obs \\
\hline Offer (\$m) & 5 & 13.8 & 39.9 & 108.6 & 174.9 & 232.9 & 406.2 & 1740.9 & 209.2 & 427 \\
Direct Equity Costs (\% offer) & 0 & 0 & 0 & 0 & 1.7 & 0 & 7 & 29.33 & 5.43 & 397 \\
Indirect Equity Costs (\% offer) & -40.8 & 0 & 0 & 1.92 & 3.62 & 6.68 & 10.83 & 34.04 & 6.72 & 414 \\
\hline
\end{tabular}

Panel B: New Debt

\begin{tabular}{|c|c|c|c|c|c|c|c|c|c|c|}
\hline EGC & Min & $10 \mathrm{pc}$ & $25 \mathrm{pc}$ & $50 \mathrm{pc}$ & Mean & $75 \mathrm{pc}$ & $90 \mathrm{pc}$ & Max & SD & Obs. \\
\hline LT Debt Issued (\$m) & 0 & 4.41 & 14. & 47.47 & 160.59 & 161.66 & 408.38 & 2050 & 297.09 & 277 \\
\hline Before Tax Cost of Debt (\%) & 0.03 & 2.98 & 4.83 & 8.2 & 10.36 & 13.07 & 21.54 & 46.3 & 8.18 & 391 \\
\hline After Tax Cost of Debt (\%) & 0 & 0 & 0 & 3.89 & 5.68 & 8.15 & 13.63 & 41.96 & 7.28 & 391 \\
\hline ExEGC & Min & $10 \mathrm{pc}$ & $25 \mathrm{pc}$ & $50 \mathrm{pc}$ & Mean & $75 \mathrm{pc}$ & $90 \mathrm{pc}$ & Max & $\mathrm{SD}$ & Obs. \\
\hline LT Debt Iss & 0.1 & 16 & 73.61 & 348.5 & 779.64 & 1133.48 & 2265.82 & 4981.5 & 998.6 & 422 \\
\hline Before Tax Cost of Debt (\%) & 0.08 & 2.12 & 3.92 & 6.09 & 7.39 & 9.27 & 13.09 & 46.18 & 5.95 & 579 \\
\hline After Tax Cost of Debt (\%) & 0 & 0 & 0.7 & 3.92 & 4.79 & 6.75 & 10.13 & 46.18 & 5.21 & 579 \\
\hline
\end{tabular}


Table A4. Impact of EGC Status Loss on Fundraising: Tests for Larger Bandwidths

Table presents regression discontinuity (RD) estimates where the dependent variables are various measures of issuance. The OLS estimates are based on equation (1); the IV estimates are based on equations (2.1) and (2.2). In each panel, models (1) - (4) display results for Log (New Equity) defined as the natural logarithm of one plus the dollar value of common stock issued by the firm via seasoned public offers (SPOs) during a fiscal year. Models (5) - (8) for New Equity scaled by lagged total assets (TA). Models (9) - (12) for $\log$ (New Debt) defined as the natural logarithm of one plus the dollar value of total long-term debt issued during a fiscal year. Models (13) - (16) for New Debt scaled by lagged total assets (TA). The sample comprises firms that went public as an "Emerging Growth Company" (EGC) between April 6, 2012 and April 30, 2019. See Section 3.1 for a detailed description of the sample construction. ExEGC is a dummy equal to one for firms having a float above $\$ 700$ million at the end of second fiscal quarter that are subject to mandatory disclosure under the "Large Accelerated Filer" (LAF) regulation, and zero for firms whose float is below the threshold. The analysis is restricted to firms whose float is within a bandwidth $h \in(\$ 300$ million, $\$ 350$ million). For the IV regressions, ExEGC is the predicted treatment based on the first-stage model (2.1) using the variable $P F 700$ as an instrument. PF700 is equal to one if the firm's float six months prior to the second fiscal quarter exceeds $\$ 700$ million, and zero otherwise. In all regressions, industry and year fixed effects are included. Standard errors are clustered by firm and are reported in parentheses. $* * *, * *$, and $*$ denote significance at the $1 \%$, $5 \%$, and $10 \%$ level, respectively. See Table A1 for a detailed description of the variables.

a) $h=\$ 300$ million

\begin{tabular}{lcccc}
\hline \multirow{2}{*}{$h=300 m$} & \multicolumn{4}{c}{$\log ($ New Equity) } \\
\cline { 2 - 5 } & $(1)$ & $(2)$ & $(3)$ & $(4)$ \\
\hline ExEGC & $1.254^{* * *}$ & $1.200^{* * *}$ & 0.304 & 0.223 \\
& $(0.234)$ & $(0.253)$ & $(0.553)$ & $(0.600)$ \\
\hline Controls & $\mathrm{N}$ & $\mathrm{Y}$ & $\mathrm{N}$ & $\mathrm{Y}$ \\
Industry FE & $\mathrm{Y}$ & $\mathrm{Y}$ & $\mathrm{Y}$ & $\mathrm{Y}$ \\
Time FE & $\mathrm{Y}$ & $\mathrm{Y}$ & $\mathrm{Y}$ & $\mathrm{Y}$ \\
\hline Observations & 431 & 366 & 431 & 366 \\
$\mathrm{R}^{2}$ & 0.194 & 0.258 & 0.156 & 0.219 \\
\hline First-stage $\mathrm{R}^{2}$ & & & 0.232 & 0.262
\end{tabular}

First Stage F-stat $\begin{array}{cc}0.232 & 0.262 \\ 87.604 & 59.151\end{array}$

\begin{tabular}{cccc}
\multicolumn{4}{c}{ New Equity/Assets t-1 } \\
\hline$(5)$ & $(6)$ & $(7)$ & $(8)$ \\
\hline $0.273^{* * *}$ & $0.326^{* * *}$ & -0.108 & -0.036 \\
$(0.068)$ & $(0.062)$ & $(0.138)$ & $(0.130)$
\end{tabular}

\begin{tabular}{cccc}
$(0.068)$ & $(0.062)$ & $(0.138)$ & $(0.130)$ \\
\hline $\mathrm{N}$ & $\mathrm{Y}$ & $\mathrm{N}$ & $\mathrm{Y}$ \\
$\mathrm{Y}$ & $\mathrm{Y}$ & $\mathrm{Y}$ & $\mathrm{Y}$ \\
$\mathrm{Y}$ & $\mathrm{Y}$ & $\mathrm{Y}$ & $\mathrm{Y}$ \\
\hline 363 & 363 & 363 & 363 \\
0.212 & 0.422 & 0.129 & 0.353 \\
\hline & & 0.253 & 0.266 \\
& & 83.95 & 54.093
\end{tabular}

\begin{tabular}{cccc}
\multicolumn{4}{c}{$\log ($ New Debt) } \\
\hline$(9)$ & $(10)$ & $(11)$ & $(12)$ \\
\hline $0.447^{*}$ & 0.389 & 0.816 & $1.068^{*}$ \\
$(0.242)$ & $(0.249)$ & $(0.577)$ & $(0.589)$ \\
\hline $\mathrm{N}$ & $\mathrm{Y}$ & $\mathrm{N}$ & $\mathrm{Y}$ \\
$\mathrm{Y}$ & $\mathrm{Y}$ & $\mathrm{Y}$ & $\mathrm{Y}$ \\
$\mathrm{Y}$ & $\mathrm{Y}$ & $\mathrm{Y}$ & $\mathrm{Y}$ \\
\hline 431 & 366 & 431 & 366 \\
0.313 & 0.364 & 0.309 & 0.350 \\
\hline & & 0.232 & 0.262 \\
& & 87.604 & 59.151 \\
\hline
\end{tabular}

\begin{tabular}{cccc}
\multicolumn{4}{c}{ New Debt/Assets $t-1$} \\
\hline$(13)$ & $(14)$ & $(15)$ & $(16)$ \\
\hline $0.140^{* *}$ & $0.150^{* *}$ & $0.256^{*}$ & $0.346^{* *}$ \\
$(0.069)$ & $(0.071)$ & $(0.140)$ & $(0.152)$ \\
\hline $\mathrm{N}$ & $\mathrm{Y}$ & $\mathrm{N}$ & $\mathrm{Y}$ \\
$\mathrm{Y}$ & $\mathrm{Y}$ & $\mathrm{Y}$ & $\mathrm{Y}$ \\
$\mathrm{Y}$ & $\mathrm{Y}$ & $\mathrm{Y}$ & $\mathrm{Y}$ \\
\hline 354 & 354 & 354 & 354 \\
0.224 & 0.272 & 0.214 & 0.246 \\
\hline & & 0.251 & 0.261 \\
& & 83.742 & 52.102 \\
\hline
\end{tabular}

b) $h=\$ 350$ million

\begin{tabular}{lcccc}
\hline \multirow{2}{*}{$h=350 m$} & \multicolumn{4}{c}{$\log ($ New Equity) } \\
\cline { 2 - 5 } & $(1)$ & $(2)$ & $(3)$ & $(4)$ \\
\hline ExEGC & $1.267^{* * *}$ & $1.174^{* * *}$ & 0.615 & 0.343 \\
& $(0.222)$ & $(0.236)$ & $(0.484)$ & $(0.553)$ \\
\hline Controls & $\mathrm{N}$ & $\mathrm{Y}$ & $\mathrm{N}$ & $\mathrm{Y}$ \\
Industry FE & $\mathrm{Y}$ & $\mathrm{Y}$ & $\mathrm{Y}$ & $\mathrm{Y}$ \\
Time FE & $\mathrm{Y}$ & $\mathrm{Y}$ & $\mathrm{Y}$ & $\mathrm{Y}$ \\
\hline Observations & 521 & 438 & 521 & 438 \\
$\mathrm{R}^{2}$ & 0.170 & 0.258 & 0.153 & 0.231 \\
\hline First-stage $\mathrm{R}^{2}$ & & & 0.268 & 0.305 \\
First Stage F-stat & & & 122.496 & 76.695 \\
\hline
\end{tabular}

\begin{tabular}{cccc}
\multicolumn{4}{c}{ New Equity/Assets t-1 } \\
\hline$(5)$ & $(6)$ & $(7)$ & $(8)$ \\
\hline $0.302^{* * *}$ & $0.362^{* * *}$ & 0.009 & 0.088 \\
$(0.067)$ & $(0.061)$ & $(0.123)$ & $(0.121)$ \\
\hline $\mathrm{N}$ & $\mathrm{Y}$ & $\mathrm{N}$ & $\mathrm{Y}$ \\
$\mathrm{Y}$ & $\mathrm{Y}$ & $\mathrm{Y}$ & $\mathrm{Y}$ \\
$\mathrm{Y}$ & $\mathrm{Y}$ & $\mathrm{Y}$ & $\mathrm{Y}$ \\
\hline 435 & 435 & 435 & 435 \\
0.191 & 0.430 & 0.143 & 0.392 \\
\hline & & 0.292 & 0.312 \\
& & 110.239 & 68.702 \\
\end{tabular}

\begin{tabular}{cccc}
\multicolumn{4}{c}{ New Debt/Assets $\mathrm{t}-1$} \\
\hline$(13)$ & $(14)$ & $(15)$ & $(16)$ \\
\hline $0.140^{* *}$ & $0.135^{* *}$ & $0.257^{* *}$ & $0.322^{* *}$ \\
$(0.068)$ & $(0.066)$ & $(0.130)$ & $(0.138)$ \\
\hline $\mathrm{N}$ & $\mathrm{Y}$ & $\mathrm{N}$ & $\mathrm{Y}$ \\
$\mathrm{Y}$ & $\mathrm{Y}$ & $\mathrm{Y}$ & $\mathrm{Y}$ \\
$\mathrm{Y}$ & $\mathrm{Y}$ & $\mathrm{Y}$ & $\mathrm{Y}$ \\
\hline 435 & 435 & 435 & 435 \\
0.245 & 0.303 & 0.236 & 0.282 \\
\hline & & 0.291 & 0.308 \\
& & 109.678 & 66.595
\end{tabular}


Table A5. EGC Fundraising by Listing Year: Tests for Smaller Bandwidths

Table presents OLS regression estimates based on equation (1) where the dependent variables are various measures of issuance. New Equity (D) is a dummy equal to one if the firm issued new equity via seasoned public offers (SPOs) during a fiscal year. New Debt $(D)$ is a dummy equal to one if the firm issued log-term debt during a fiscal year. The sample comprises firms that went public as an "Emerging Growth Company" (EGC) between April 6, 2012 and April 30, 2019. See Section 3.1 for a detailed description of the sample construction. The analysis is performed at various levels of the bandwidth $h \in[\$ 150$ million, $\$ 300$ million] of the float with respect the LAF treatment cutoff. ExEGC is a dummy equal to one for firms having a float above $\$ 700$ million at the end of second fiscal quarter that are subject to mandatory disclosure under the "Large Accelerated Filer" (LAF) regulation, and zero for firms whose float is below the threshold. The variable Listing Age is split into individual year dummies. In all regressions, industry-year fixed effects are included. Standard errors are clustered by firm and reported in parentheses. ***, **, and * denote significance at the $1 \%, 5 \%$, and $10 \%$ level, respectively. See Table A1 for a detailed description of the variables.

\begin{tabular}{|c|c|c|c|c|c|c|c|c|}
\hline & \multicolumn{4}{|c|}{ New Equity (D) } & \multicolumn{4}{|c|}{ New Debt (D) } \\
\hline & $\begin{array}{c}h=\$ 150 \mathrm{~m} \\
(1)\end{array}$ & $\begin{array}{c}h=200 \mathrm{~m} \\
(2)\end{array}$ & $\begin{array}{l}h=250 \mathrm{~m} \\
\quad(3)\end{array}$ & $\begin{array}{c}h=300 \mathrm{~m} \\
(4)\end{array}$ & $\begin{array}{c}h=\$ 150 \mathrm{~m} \\
(5)\end{array}$ & $\begin{array}{c}h=200 \mathrm{~m} \\
(6)\end{array}$ & $\begin{array}{c}h=250 \mathrm{~m} \\
(7)\end{array}$ & $\begin{array}{c}h=300 \mathrm{~m} \\
(8)\end{array}$ \\
\hline$t=\mathrm{IPO}$ year +1 & $\begin{array}{l}-0.051 \\
(0.195)\end{array}$ & $\begin{array}{l}-0.041 \\
(0.162)\end{array}$ & $\begin{array}{c}0.024 \\
(0.154)\end{array}$ & $\begin{array}{c}0.069 \\
(0.108)\end{array}$ & $\begin{array}{c}0.155 \\
(0.178)\end{array}$ & $\begin{array}{c}0.109 \\
(0.130)\end{array}$ & $\begin{array}{c}0.012 \\
(0.117)\end{array}$ & $\begin{array}{c}0.079 \\
(0.113)\end{array}$ \\
\hline$t=\mathrm{IPO}$ year +2 & $\begin{array}{c}0.143 \\
(0.282)\end{array}$ & $\begin{array}{l}-0.032 \\
(0.212)\end{array}$ & $\begin{array}{l}-0.030 \\
(0.203)\end{array}$ & $\begin{array}{l}-0.101 \\
(0.131)\end{array}$ & $\begin{array}{c}0.233 \\
(0.267)\end{array}$ & $\begin{array}{l}0.346^{*} \\
(0.191)\end{array}$ & $\begin{array}{c}0.040 \\
(0.165)\end{array}$ & $\begin{array}{c}0.020 \\
(0.116)\end{array}$ \\
\hline$t=\mathrm{IPO}$ year +3 & $\begin{array}{l}-0.360^{*} \\
(0.192)\end{array}$ & $\begin{array}{c}-0.414^{* *} \\
(0.170)\end{array}$ & $\begin{array}{c}-0.328^{* *} \\
(0.142)\end{array}$ & $\begin{array}{c}-0.275 * * * \\
(0.105)\end{array}$ & $\begin{array}{c}0.273 \\
(0.226)\end{array}$ & $\begin{array}{l}0.310^{*} \\
(0.170)\end{array}$ & $\begin{array}{c}0.112 \\
(0.161)\end{array}$ & $\begin{array}{c}0.009 \\
(0.131)\end{array}$ \\
\hline$t=\mathrm{IPO}$ year +4 & $\begin{array}{c}0.166 \\
(0.266)\end{array}$ & $\begin{array}{l}-0.008 \\
(0.178)\end{array}$ & $\begin{array}{c}0.062 \\
(0.160)\end{array}$ & $\begin{array}{c}0.008 \\
(0.112)\end{array}$ & $\begin{array}{c}0.056 \\
(0.238)\end{array}$ & $\begin{array}{l}-0.048 \\
(0.149)\end{array}$ & $\begin{array}{l}-0.025 \\
(0.164)\end{array}$ & $\begin{array}{c}0.002 \\
(0.138)\end{array}$ \\
\hline$t=\mathrm{IPO}$ year +5 & $\begin{array}{c}0.258 \\
(0.293)\end{array}$ & $\begin{array}{c}0.118 \\
(0.240)\end{array}$ & $\begin{array}{c}0.182 \\
(0.214)\end{array}$ & $\begin{array}{c}0.148 \\
(0.188)\end{array}$ & $\begin{array}{l}-0.515 \\
(0.330)\end{array}$ & $\begin{array}{l}-0.163 \\
(0.124)\end{array}$ & $\begin{array}{c}-0.268 * * * \\
(0.102)\end{array}$ & $\begin{array}{l}-0.241^{*} \\
(0.123)\end{array}$ \\
\hline$t=\mathrm{IPO}$ year +6 & $\begin{array}{l}0.188 \\
(0.307)\end{array}$ & $\begin{array}{l}-0.294 \\
(0.182)\end{array}$ & $\begin{array}{l}0.412^{* *} \\
(0.179)\end{array}$ & $\begin{array}{c}0.399 * * * \\
(0.128)\end{array}$ & $\begin{array}{l}-1.057^{* * *} \\
(0.272)\end{array}$ & $\begin{array}{l}-1.025^{* * *} \\
(0.154)\end{array}$ & $\begin{array}{c}-0.406^{* * *} \\
(0.127)\end{array}$ & $\begin{array}{c}-0.354 * * * \\
(0.107)\end{array}$ \\
\hline ExEGC & $\begin{array}{l}0.048 \\
(0.177)\end{array}$ & $\begin{array}{l}-0.036 \\
(0.144)\end{array}$ & $\begin{array}{c}0.097 \\
(0.150)\end{array}$ & $\begin{array}{c}0.083 \\
(0.131)\end{array}$ & $\begin{array}{c}0.191 \\
(0.235)\end{array}$ & $\begin{array}{c}0.166 \\
(0.148)\end{array}$ & $\begin{array}{c}0.008 \\
(0.152)\end{array}$ & $\begin{array}{c}0.018 \\
(0.141)\end{array}$ \\
\hline$t=\mathrm{IPO}$ year $+1 \times$ ExEGC & $\begin{array}{c}0.095 \\
(0.235)\end{array}$ & $\begin{array}{c}0.077 \\
(0.168)\end{array}$ & $\begin{array}{l}-0.014 \\
(0.172)\end{array}$ & $\begin{array}{l}-0.051 \\
(0.157)\end{array}$ & $\begin{array}{l}-0.144 \\
(0.262)\end{array}$ & $\begin{array}{l}-0.126 \\
(0.173)\end{array}$ & $\begin{array}{c}0.056 \\
(0.177)\end{array}$ & $\begin{array}{c}0.007 \\
(0.160)\end{array}$ \\
\hline$t=\mathrm{IPO}$ year $+2 \times$ ExEGC & $\begin{array}{l}-0.233 \\
(0.305)\end{array}$ & $\begin{array}{l}-0.059 \\
(0.230)\end{array}$ & $\begin{array}{l}-0.110 \\
(0.224)\end{array}$ & $\begin{array}{l}-0.029 \\
(0.180)\end{array}$ & $\begin{array}{l}-0.313 \\
(0.332)\end{array}$ & $\begin{array}{c}-0.465^{* *} \\
(0.211)\end{array}$ & $\begin{array}{l}-0.095 \\
(0.217)\end{array}$ & $\begin{array}{l}-0.097 \\
(0.177)\end{array}$ \\
\hline$t=\mathrm{IPO}$ year $+3 \times$ ExEGC & $\begin{array}{c}0.314 \\
(0.277)\end{array}$ & $\begin{array}{c}0.382 \\
(0.264)\end{array}$ & $\begin{array}{c}0.244 \\
(0.222)\end{array}$ & $\begin{array}{c}0.241 \\
(0.159)\end{array}$ & $\begin{array}{l}-0.418 \\
(0.291)\end{array}$ & $\begin{array}{c}-0.412 * * \\
(0.197)\end{array}$ & $\begin{array}{l}-0.183 \\
(0.202)\end{array}$ & $\begin{array}{l}-0.049 \\
(0.166)\end{array}$ \\
\hline$t=\mathrm{IPO}$ year $+4 \times$ ExEGC & $\begin{array}{l}-0.159 \\
(0.333)\end{array}$ & $\begin{array}{c}0.021 \\
(0.185)\end{array}$ & $\begin{array}{l}-0.124 \\
(0.176)\end{array}$ & $\begin{array}{l}-0.031 \\
(0.132)\end{array}$ & $\begin{array}{l}-0.127 \\
(0.290)\end{array}$ & $\begin{array}{l}-0.037 \\
(0.175)\end{array}$ & $\begin{array}{l}-0.003 \\
(0.185)\end{array}$ & $\begin{array}{c}0.003 \\
(0.160)\end{array}$ \\
\hline$t=\mathrm{IPO}$ year $+5 \times$ ExEGC & $\begin{array}{l}-0.370 \\
(0.269)\end{array}$ & $\begin{array}{l}-0.061 \\
(0.274)\end{array}$ & $\begin{array}{l}-0.073 \\
(0.217)\end{array}$ & $\begin{array}{l}-0.008 \\
(0.177)\end{array}$ & $\begin{array}{c}0.320 \\
(0.468)\end{array}$ & $\begin{array}{l}-0.003 \\
(0.183)\end{array}$ & $\begin{array}{c}0.224 \\
(0.186)\end{array}$ & $\begin{array}{c}0.267 \\
(0.179)\end{array}$ \\
\hline$t=\mathrm{IPO}$ year $+6 \times$ ExEGC & $\begin{array}{c}0.000 \\
(.)\end{array}$ & $\begin{array}{c}0.000 \\
(.)\end{array}$ & $\begin{array}{c}0.000 \\
(.)\end{array}$ & $\begin{array}{c}-0.632 * * * \\
(0.147)\end{array}$ & $\begin{array}{c}0.000 \\
(.)\end{array}$ & $\begin{array}{c}0.000 \\
(.)\end{array}$ & $\begin{array}{c}0.000 \\
(.)\end{array}$ & $\begin{array}{c}1.159^{* * *} \\
(0.157)\end{array}$ \\
\hline Constant & $\begin{array}{l}-1.182 * \\
(0.650)\end{array}$ & $\begin{array}{l}-0.101 \\
(0.374)\end{array}$ & $\begin{array}{c}0.134 \\
(0.317)\end{array}$ & $\begin{array}{c}0.168 \\
(0.315)\end{array}$ & $\begin{array}{c}2.305 * * * \\
(0.529)\end{array}$ & $\begin{array}{c}1.647 * * * \\
(0.533)\end{array}$ & $\begin{array}{c}0.214 \\
(0.645)\end{array}$ & $\begin{array}{c}0.438 \\
(0.547)\end{array}$ \\
\hline $\begin{array}{l}\text { Firm \& Macro Controls } \\
\text { Industry/Year FE }\end{array}$ & $\begin{array}{l}\mathrm{Y} \\
\mathrm{Y}\end{array}$ & $\begin{array}{l}\mathrm{Y} \\
\mathrm{Y}\end{array}$ & $\begin{array}{l}\mathrm{Y} \\
\mathrm{Y}\end{array}$ & $\begin{array}{l}\mathrm{Y} \\
\mathrm{Y}\end{array}$ & $\begin{array}{l}\mathrm{Y} \\
\mathrm{Y}\end{array}$ & $\begin{array}{l}\mathrm{Y} \\
\mathrm{Y}\end{array}$ & $\begin{array}{l}\mathrm{Y} \\
\mathrm{Y}\end{array}$ & $\begin{array}{l}\mathrm{Y} \\
\mathrm{Y}\end{array}$ \\
\hline $\begin{array}{l}\text { Observations } \\
\text { Adjusted } \mathrm{R}^{2}\end{array}$ & $\begin{array}{c}383 \\
0.567 \\
\end{array}$ & $\begin{array}{c}460 \\
0.549 \\
\end{array}$ & $\begin{array}{c}557 \\
0.522 \\
\end{array}$ & $\begin{array}{c}662 \\
0.496 \\
\end{array}$ & $\begin{array}{c}383 \\
0.631 \\
\end{array}$ & $\begin{array}{c}460 \\
0.611 \\
\end{array}$ & $\begin{array}{c}557 \\
0.562 \\
\end{array}$ & $\begin{array}{c}662 \\
0.538 \\
\end{array}$ \\
\hline
\end{tabular}


Table A6. Which Investments Affect Growth Opportunities?

Table presents OLS regression discontinuity (RD) estimates where the dependent variable measures growth opportunities. The OLS estimates are based on equation (1). The dependent variable is the firm's Tobin's $q$ each year. We explore which investment policies (internal and external) affect future growth opportunities. The sample comprises firms that went public as an "Emerging Growth Company" (EGC) between April 6, 2012 and April 30, 2019. See Section 3.1 for a detailed description of the sample construction. ExEGC is a dummy equal to one for firms having a float above $\$ 700$ million at the end of second fiscal quarter that are subject to mandatory disclosure under the "Large Accelerated Filer" (LAF) regulation, and zero for firms whose float is below the threshold. To minimize the effect of confounding factors, the analysis is restricted to firms whose float is within a bandwidth $h=\$ 250$ million around the LAF cutoff. In all regressions, industry and year fixed effects are included. Standard errors are clustered by firm and reported in parentheses. $* * *, * *$, and $*$ denote significance at the $1 \%, 5 \%$, and $10 \%$ level, respectively. See Table A1 for a description of the variables.

\begin{tabular}{|c|c|c|c|c|c|c|}
\hline & \multicolumn{6}{|c|}{ Tobin's $q$} \\
\hline & (1) & (2) & (3) & (4) & (5) & (6) \\
\hline ExEGC & $\begin{array}{l}0.586^{*} \\
(0.235)\end{array}$ & $\begin{array}{c}0.556 * * \\
(0.197)\end{array}$ & $\begin{array}{c}0.593 * * \\
(0.206)\end{array}$ & $\begin{array}{l}0.544^{*} \\
(0.228)\end{array}$ & $\begin{array}{l}0.529^{*} \\
(0.226)\end{array}$ & $\begin{array}{c}0.480 \\
(0.243)\end{array}$ \\
\hline Internal Investments & & & & & & \\
\hline Capex/Sales & $\begin{array}{c}0.527 \\
(1.386)\end{array}$ & & & & & \\
\hline ExEGC $\times$ Capex/Sales & $\begin{array}{l}-1.096 \\
(1.321)\end{array}$ & & & & & \\
\hline PPE/Sales & & $\begin{array}{c}0.014 \\
(0.240)\end{array}$ & & & & \\
\hline ExEGC $\times$ PPE/Sales & & $\begin{array}{l}-0.252 \\
(0.463)\end{array}$ & & & & \\
\hline R\&D/Sales & & & $\begin{array}{l}-0.005 \\
(0.008)\end{array}$ & & & \\
\hline ExEGC $\times$ R\&D/Sales & & & $\begin{array}{c}-0.106 * * \\
(0.033)\end{array}$ & & & \\
\hline External Investments & & & & & & \\
\hline Acquisition (D) & & & & $\begin{array}{c}1.342 * * * \\
(0.304)\end{array}$ & & \\
\hline ExEGC $\times$ Acquisition $(D)$ & & & & $\begin{array}{c}-0.764 \\
(0.904)\end{array}$ & & \\
\hline Log (Acquisition Value) & & & & & $\begin{array}{c}0.288 * * * \\
(0.050)\end{array}$ & \\
\hline ExEGC $\times \log ($ Acquisition Value $)$ & & & & & $\begin{array}{l}-0.156 \\
(0.200)\end{array}$ & \\
\hline All Cash Acquisition (D) & & & & & & $\begin{array}{c}1.007 \\
(0.785)\end{array}$ \\
\hline ExEGC $\times$ All Cash Acquisition (D) & & & & & & $\begin{array}{c}-0.352 \\
(1.505)\end{array}$ \\
\hline Controls & $\mathrm{Y}$ & $\mathrm{Y}$ & $\mathrm{Y}$ & $\mathrm{Y}$ & $\bar{Y}$ & $\mathrm{Y}$ \\
\hline Industry/Year FE & Y & Y & Y & Y & $\mathrm{Y}$ & $\mathrm{Y}$ \\
\hline Observations & 197 & 197 & 197 & 197 & 197 & 197 \\
\hline Adjusted $\mathrm{R}^{2}$ & 0.533 & 0.533 & 0.541 & 0.542 & 0.542 & 0.535 \\
\hline
\end{tabular}




\section{B. Impact of the JOBS Act on US equity issuance: International evidence}

To understand the extent to which the JOBS Act affected seasoned public offering (SPO) activity in US public markets, we compare US SPO activity (the treated group) against an international control sample. Data for the international sample is obtained from Capital IQ, and covers nine countries with the largest and most liquid public equity markets comparable to the US: Canada, United Kingdom, France, Germany, Italy, Australia, Japan, Hong Kong, and Singapore. We apply the methodology described in section 3.1 and restrict the international control sample to firms with annual revenue below $\$ 1$ billion.

Panel (a) of Figure B1 shows that prior to the JOBS Act, US SPO volume (deals per quarter) followed a trend very similar to SPO activity in the international markets. However, the mean quarterly US SPO volume has risen sharply by an average of 231\% since April 2012 relative to the pre-JOBS period. This increase is also substantially larger compared to quarterly SPO volume in the international control sample, which has remained relatively flat since 2007 (except for a temporary dip during the great financial crisis). This difference in trends between the treated and control groups provides strong evidence that the growth in US SPO activity following the JOBS Act is economically significant. Panel (b) compares SPO activity among US firms that went public as an "Emerging Growth Company" (EGC) and US NonEGC firms that went public before the Act and do not qualify for its provisions. We see that SPO activity among EGC firms has been rising steadily over time (both in absolute and percentage terms) compared to NonEGC firms.

Table B1 presents descriptive statistics of SPOs by US firms with revenue below $\$ 1$ billion in the period surrounding the JOBS Act. Panel A compares SPO offer and issuer characteristics in the pre-(January 1, 2000 - April 4, 2012) and post-JOBS periods (April 6, 2012 - December $31,2017)$. SPOs after the Act raised, on average, $\$ 17$ million more than similar offers before the Act, and are underwritten by larger syndicates. The duration between filing and completion (withdrawal) of an SPO reduced by $77 \%$ to a mean of just 8.8 days after the Act. This suggests that the de-risking provisions of the JOBS Act (Dambra, Field and Gustafson, 2015), which permit EGCs to file offers confidentially and to communicate with institutional investors before filing, are enabling faster completion (withdrawal) of the offer. Fees charged by underwriters for servicing SPOs increased by only $0.47 \%$ after Title I, possibly because the underlying stock 
is already trading and requires fewer underwriting efforts than, say, IPOs. However, underpricing increased by $8.4 \%$ on average. For the mean post-JOBS SPO with $\$ 78.5$ million in gross proceeds, the increase in underpricing translates to $\$ 6.57$ million in mean forgone proceeds. One possible explanation for the greater underpricing is that fewer disclosures made by EGC firms impedes price discovery. The extra money left on the table is therefore meant to compensate investors for this information asymmetry. Panel B compares the characteristics of US SPOs and their issuers in the period following the Act. EGCs raise less money from SPOs relative to NonEGC firms that went public before the Act and do not qualify for its exemptions. EGCs also leave up to $3.6 \%$ more money on the table on average (relative to offer size) compared to NonEGCs. The mean EGC is also 9 years younger, and smaller in size, revenue, and employees compared to the mean NonEGC firm.

To estimate the causal effect of the JOBS Act on US SPO activity, we begin by estimating the following event-study specification:

$$
Y_{i j t}=\alpha+\sum_{k=-24, k \neq-1}^{24} \beta_{k}\left[\text { treated }_{i} \times \mathbb{I}(t=k)\right]+\mu_{j}+v_{t}+\varepsilon_{i j t}
$$

where $Y_{i j t}$ is a measure of SPO activity in region $i$ within industry $j$ in year-quarter $t$. SPO activity is estimated per region-industry-quarter as (i) number of SPOs scaled by total number of publicly listed firms (SPO volume), and (ii) gross SPO proceeds scaled by total stock market capitalization (SPO proceeds). Treated $i$ is a dummy equal to one if the region $i$ is the US, and zero if $i$ is rest of the world (RoW) or any other non-US region. The coefficients of interest are the $\beta_{k}$ terms, which tell us whether and when the JOBS Act had a significant impact on SPO activity in the treated group (US), relative to the control group. Our hypothesis is that these coefficients will be significantly greater than zero for $k \geq 0$ (i.e., quarters after the JOBS Act) and not different to zero for $k<0$ (i.e., quarters before the JOBS Act). We set $\beta_{k}=0$ for $k=$ -1 , denoting the baseline parameter against which the other coefficients are estimated. Our event window starts 24 quarters before the JOBS Act took effect, and ends 24 quarters afterward. The other terms in the above equation are industry and year-quarter fixed effects, and a constant term $\alpha$. The error term $\varepsilon_{i j t}$ is normally distributed and assumed to be 
uncorrelated with the main regressors.

Figure B2 shows clear effects of the JOBS Act on US SPO volume, but not in US SPO proceeds. Panel (a) shows that the JOBS Act led to a 2.1\% increase in US SPO volume in the quarter after the Act went into effect $(k=1)$. This increase is persistent and relatively stable during subsequent quarters. In contrast, there is no change in aggregate proceeds raised from SPOs by US issuers following the Act. Panels (b) and (c) show similar event-study estimates for alternative control samples based on specific sub-regions (Canada/European Union in panel (b), Asia-Pacific in panel (c)). The results are consistent to those obtained in panel (a).

Extant literature shows that greater information uncertainty and the decline in issuer quality are two major factors that contributed to a rise in IPO underpricing after the JOBS Act. An early study by Barth, Landsman and Taylor (2017) notes that EGCs mitigate this uncertainty by voluntarily disclosing more information post IPO. If such initiatives successfully reduce information asymmetry, then follow-on offers by EGCs should not be more underpriced compared to similar offers made by NonEGC firms. Conversely, if voluntary disclosure does not resolve the uncertainty associated with an EGC firm, then investors will demand greater compensation (in the form of more underpricing) to fund a follow-on offer by that firm.

To test these hypotheses, we compare SPOs in the US to SPOs in other international markets in the period surrounding the JOBS Act. Our identification strategy relies on the argument that US SPOs, particularly those conducted by EGC firms, are likely to be impacted by the Act whereas similar offers in foreign markets are unlikely to affected by the Act's passage.

To create a relevant sample for empirical analysis, we match each US SPO in our sample to a control group of three nearest NonUS SPOs from our international sample. The matching is done using the propensity scores (PS) method that compares various observable characteristics of issuers in the treated and control groups. For each set of acceptable matches, we impose an additional restriction that the matching is done in the same offer year and period (i.e., matched US and NonUS IPOs both occur pre-JOBS, or both occur post-JOBS), and among issuers within the same two-digit SIC industry. To minimize bias, we also restrict the sample to maintain similar calendar length before (January 1, 2008 to April 4, 2012) and after (April 6, 2012 and December 31, 2017) the Act. Table B3 shows that the matched US and NonUS SPOs have no significant differences in observable characteristics (see Table B3). 
Our analysis is based on the following difference-in-differences specification:

$$
\begin{aligned}
\text { SPO Underpricing }=\gamma_{1}[P O S T & \times \text { US Issuer }]+\gamma_{2}[\text { POST } \times \text { US Issuer } \times E G C] \\
& +\gamma_{3} X^{\prime}+\mu_{i}+\delta_{j}+\lambda_{t}+\varepsilon_{i j t}
\end{aligned}
$$

where the outcome variable SPO underpricing follows from Corwin (2003), and is estimated as minus one times the difference between previous day's closing price and the SPO offer price, scaled by the previous day's closing price. This variable is equivalent to Indirect Equity Costs mentioned in Section 3.1 and Table A3. The first independent variable of interest is the interaction term POST $\times$ US Issuer that captures potential changes in the underpricing of US SPOs vis-à-vis similar offers in other markets. We also include a triple interaction $P O S T \times U S$ Issuer $\times E G C$, which serves to differentiate between EGC and NonEGC firms that are both active in the US SPO market in the aftermath of the JOBS Act. $X$ denotes a set of observable controls for issuer as well as country-specific economic and stock market characteristics. Lastly, the regressions include country, industry, and year fixed effects with robust standard errors.

Table B4 presents difference-in-differences estimates of the JOBS Act's impact on US SPO underpricing based on equation (B.2). The coefficients of POST $\times$ US Issuer are consistently positive and significant, implying a general increase in the underpricing of US SPOs relative to other foreign markets following Title I. The positive and highly significant interaction term $P O S T \times U S$ Issuer $\times E G C$ suggests that EGCs pay about $14.5 \%$ more in terms of underpricing than other NonEGC issuers raising capital in the US SPO market. This is equivalent to about $\$ 15.4$ million in forgone proceeds for the mean SPO by an EGC.

Overall, these findings show that EGC firms pay more to raise follow-on equity in US public markets. We also conclude from these results that any post IPO voluntary disclosure made by EGC firms does not help in lowering their public equity issuance costs. 
Figure B1. SPO activity around the JOBS Act

Panel (a) compares quarterly volume of secondary public equity offers (SPOs) in the US versus rest of the world (RoW) comprising nine countries with the largest and most liquid public equity markets: Canada, United Kingdom, France, Germany, Italy, Australia, Japan, Hong Kong, and Singapore. The US and RoW SPO samples are constructed from Capital IQ based on the methodology described in Section 3.1. Panel (b) compares SPO activity between US firms that went public as an "Emerging Growth Company" (EGC) and RoW. The sample period is from April 6, 2012 to April 30, 2019.

a) US versus other developed countries

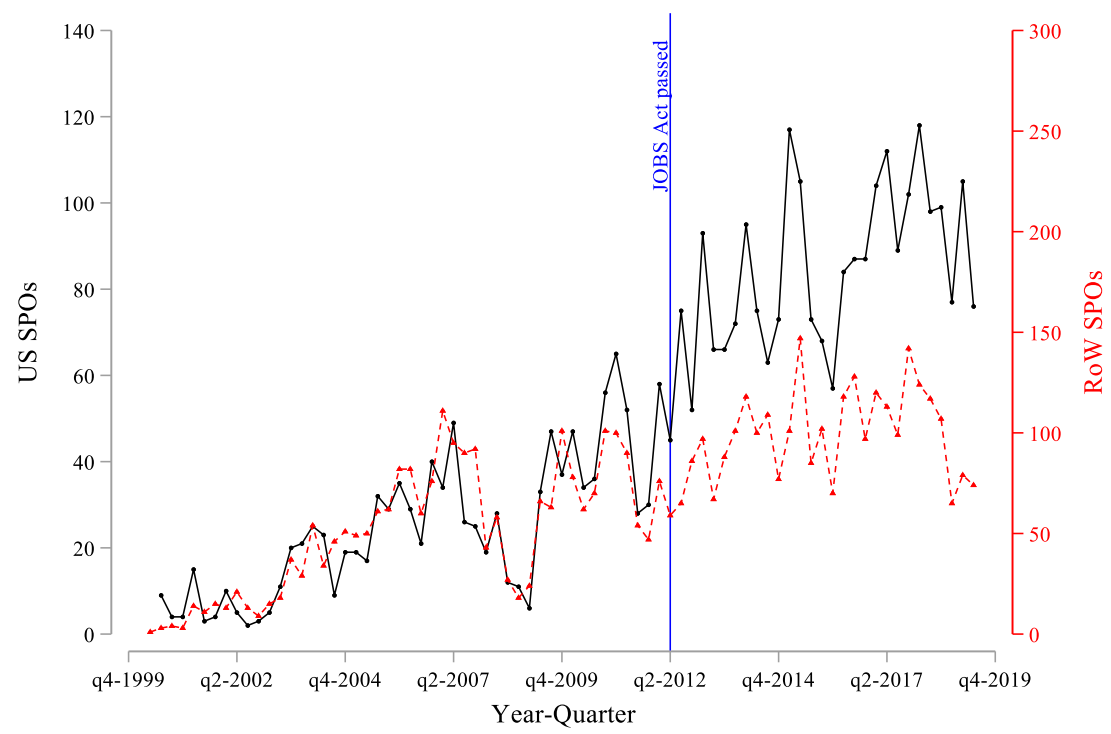

b) US SPO activity: EGC versus NonEGC firms
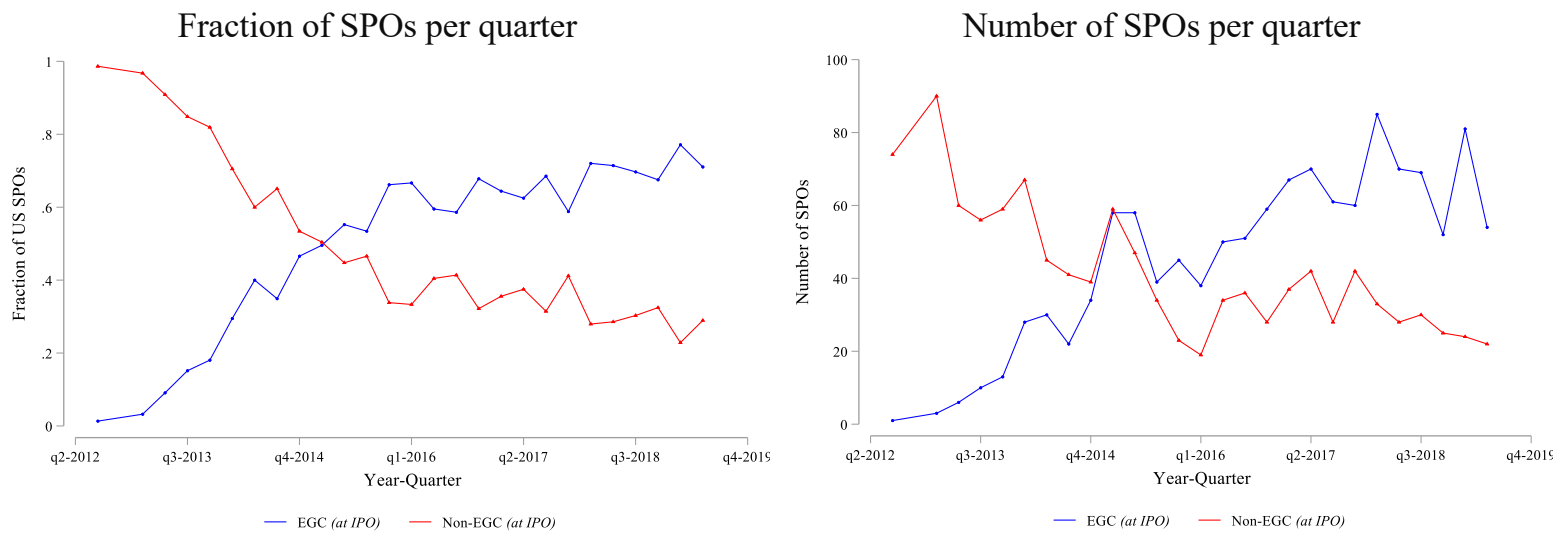
Figure B2. JOBS Act and SPO activity: US versus developed countries

Figures plot the coefficients from an event study analysis on the effect of the JOBS Act on US SPO activity. The regression specification used for this analysis is as follows:

$$
Y_{i j t}=\alpha+\sum_{k=-24, k \neq-1}^{24} \beta_{k}\left[\text { treated }_{i} \times \mathbb{I}(t=k)\right]+\mu_{j}+v_{t}+\varepsilon_{i j t}
$$

where $Y_{i j t}$ is a measure of SPO activity in region $i$ within industry $j$ in year-quarter $t$. SPO activity is estimated per regionindustry-quarter as (i) number of SPOs scaled by total number of publicly listed firms, and, (ii) gross SPO proceeds scaled by total stock market capitalization. Treated ${ }_{i}$ is a dummy equal to one if the region $i$ is the US, and zero if $i$ is rest of the world (RoW) or any other non-US regions. The coefficients of interest are the $\beta_{k}$ terms, which tell us whether and when the JOBS Act had a significant impact on SPO activity in the treated group (US), relative to the control group. Our hypothesis is that these coefficients will be significantly greater than zero for $k \geq 0$ (i.e., quarters after the JOBS Act) and not different to zero for $k<0$ (i.e., quarters before the JOBS Act). We set $\beta_{k}=0$ for $k=-1$, representing the baseline parameter against which the other coefficients are estimated. Our event window starts 24 quarters before the JOBS Act took effect, and ends 24 quarters afterward. The other terms in the above equation are industry and year-quarter fixed effects, and a constant term $\alpha$. The error term $\varepsilon_{i j t}$ is normally distributed and assumed to be uncorrelated with the main regressors. See the introduction to Appendix B for a description of the sample construction. Vertical bands represent $90 \%$ confidence intervals. Standard errors are clustered at the two-digit SIC industry level.

a) US versus RoW

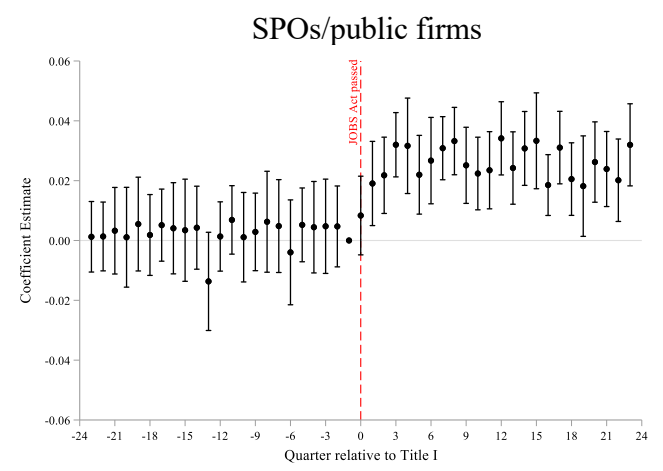

b) US versus Canada/European Union

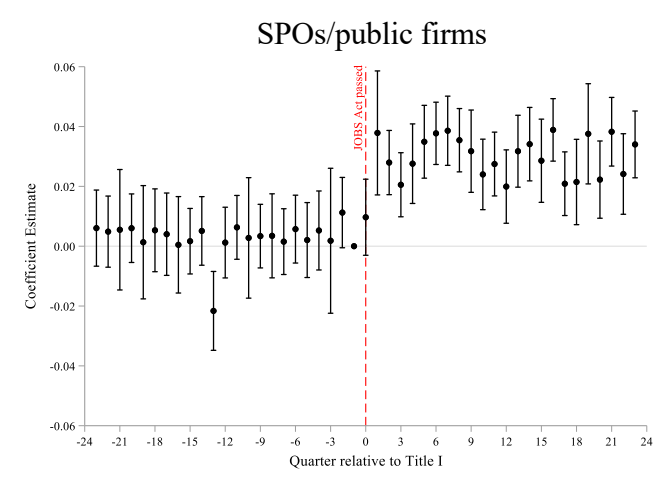

c) US versus Asia-Pacific

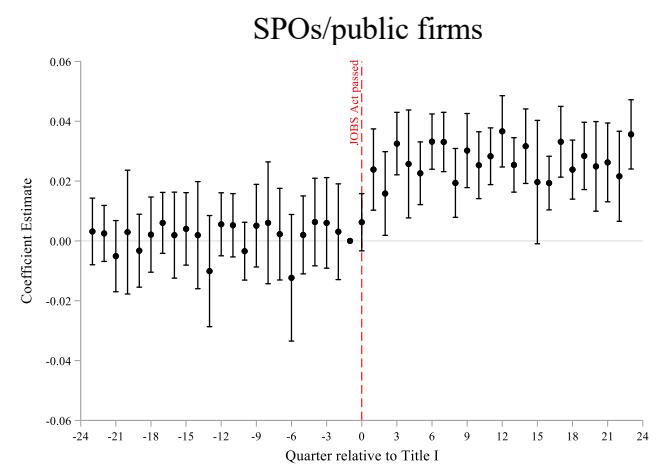

SPO proceeds/total market capitalization

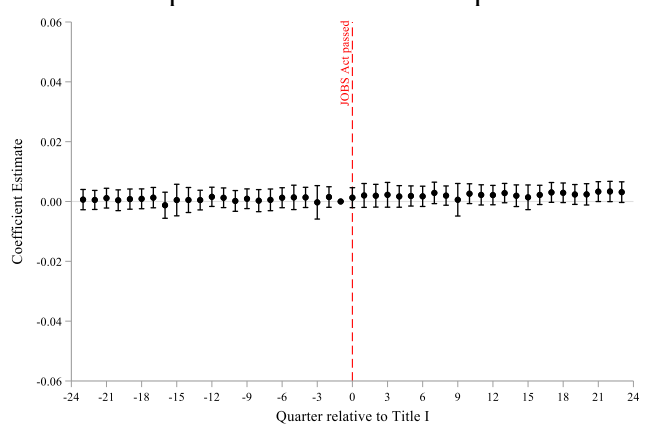

SPO proceeds/total market capitalization

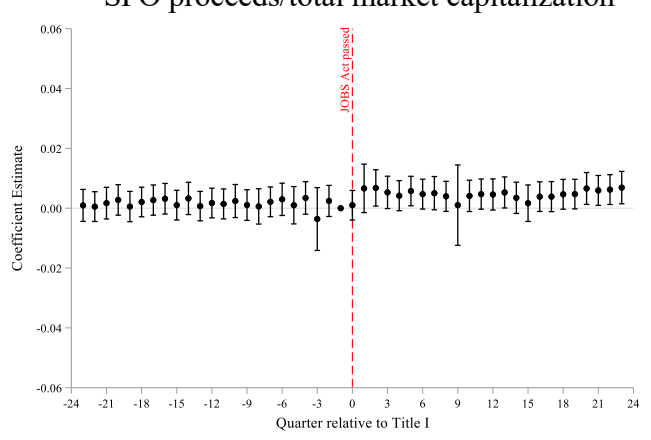

SPO proceeds/total market capitalization

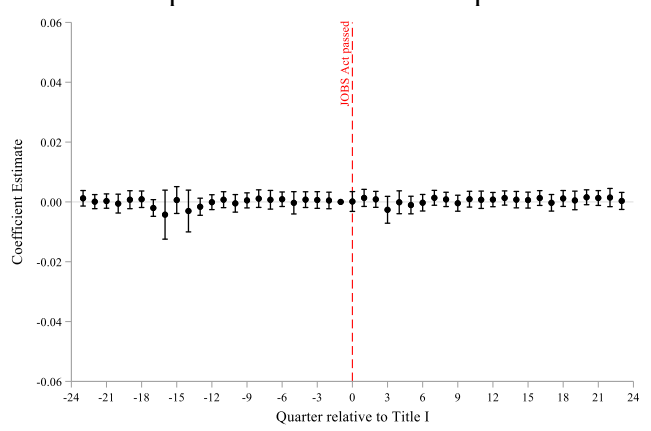


Table B1. Summary statistics: US SPOs

Table presents descriptive statistics on secondary public equity offers (SPOs) by firms with gross revenue below $\$ 1$ billion in the period surrounding the JOBS Act. See the introduction to Appendix B for a description of the sample construction. To minimize bias, we restrict the sample to maintain similar calendar length before (January 1, 2008 to April 4, 2012) and after (April 6, 2012 and December 31, 2017) the JOBS Act. Panel A compares offer and issuer characteristics for SPOs during the pre- and post-JOBS periods. Panel B compares offer and issuer characteristics for SPOs in the post-JOBS periods only between EGC and NonEGC firms. EGC firms are those that qualify for exemptions from mandatory disclosure under Title I of the JOBS Act for up to five years of the IPO. NonEGC firms are those that went public before the JOBS Act and do not qualify for such exemptions. Values are rounded to the nearest decimal for brevity. Test statistics are computed using the $t$ test for a significant change in means. ${ }^{* *}, * *$, and $*$ indicate that the difference in means is significant at the $1 \%, 5 \%$, and $10 \%$ level, respectively.

\section{a) Pre- versus Post-JOBS}

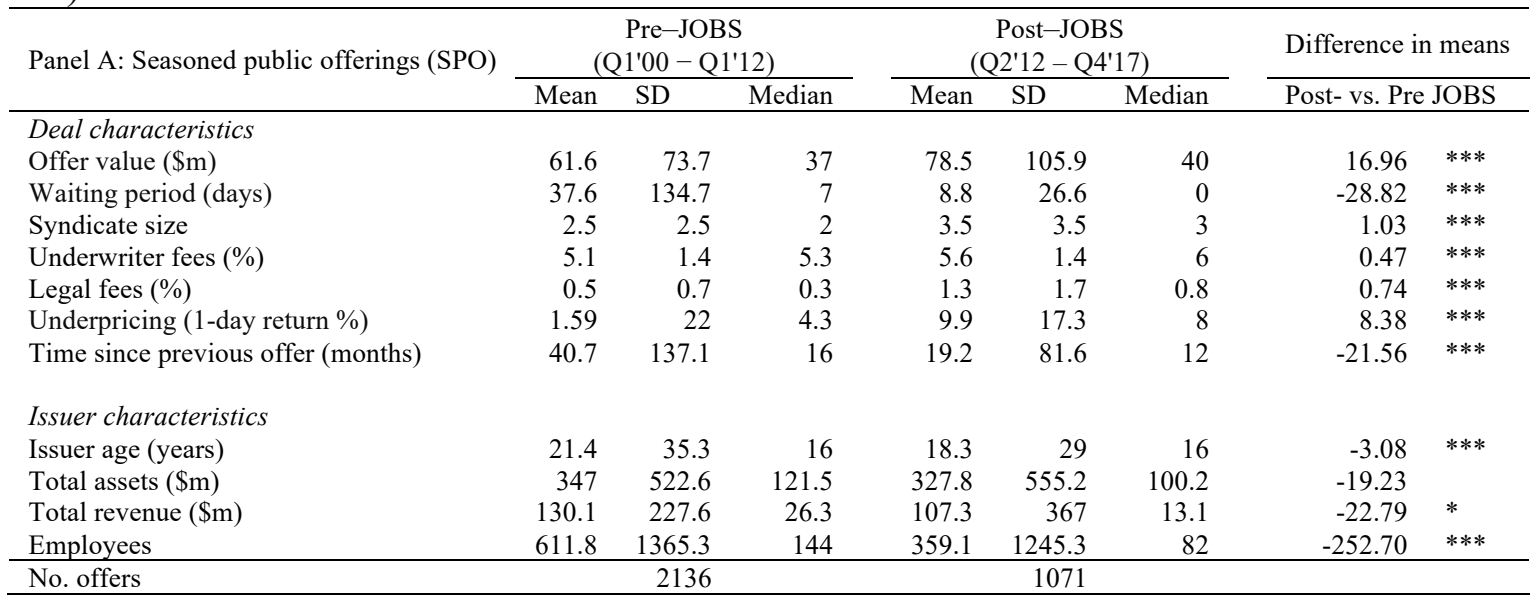

b) EGC versus NonEGC firms (Q2'2012-Q4'2017)

\begin{tabular}{|c|c|c|c|c|c|c|c|c|}
\hline Panel A: Seasoned public offerings (SPO) & \multicolumn{3}{|c|}{ NonEGC firms } & \multicolumn{3}{|c|}{ EGC firms } & \multicolumn{2}{|c|}{ Difference in means } \\
\hline \multicolumn{9}{|l|}{ Deal characteristics } \\
\hline Waiting period (days) & 11.4 & 45.7 & 0 & 9.6 & 29.1 & 0 & -1.79 & \\
\hline Syndicate size & 4.6 & 4.2 & 3 & 4.1 & 3.3 & 4 & -0.48 & \\
\hline Underwriter fees $(\%)$ & 5.2 & 1.4 & 6 & 5.3 & 1.5 & 6 & 0.1 & \\
\hline Time since previous offer (months) & 15.1 & 14.6 & 11 & 12.5 & 9 & 10 & -2.64 & $*$ \\
\hline \multicolumn{9}{|l|}{ Issuer characteristics } \\
\hline Issuer age (years) & 19.2 & 26.5 & 11 & 10 & 6.7 & 9 & -9.11 & $* * *$ \\
\hline Total assets (\$m) & 825 & 1204.3 & 131.8 & 482.5 & 870.2 & 168.6 & -342.52 & $* *$ \\
\hline
\end{tabular}


Table B2. JOBS Act and SPO activity: US versus developed countries

Table presents OLS difference-in-differences estimates of the effects of the JOBS Act on country-level SPO activity per yearquarter. See the introduction to Appendix B for a description of the sample construction. To minimize bias, we restrict the sample to maintain similar calendar length before (January 1, 2008 to April 4, 2012) and after (April 6, 2012 and December $31,2017)$ the JOBS Act. The dependent variables in Panel A is the quarterly number of SPOs scaled by the total number of publicly listed firms in a given country. The dependent variables in Panel B is the quarterly proceeds from SPOs scaled by the market capitalization of all public firms in a given country. US is dummy indicator equal to one if the country in question is the US, and zero otherwise. Post JOBS is a dummy variable equal to one if the offer was issued in the period following Title I (i.e. between April 5, 2012 and December 31, 2017, and zero if the offer was issued in the prior period (i.e. between January 1, 2008 and April 4, 2012). Stock return $t_{t-1}$ is the lagged annual return compounded monthly for a given country in the 12month period prior to the given quarter. GDP growth $_{t-l}$ is the lagged annual change in gross domestic product (GDP) at the end of the most recent calendar year, estimated in percentage terms. Country MTB is the mean of the Fama-French industry median market-to-book ratios in a given country-quarter, and is based on Doidge, Karolyi and Stulz (2013). All the specifications include country and time (year-quarter) fixed effects. Standard errors are clustered by time and reported in parentheses. $* * * * *$, and $*$ denote significance at the $1 \%, 5 \%$, and $10 \%$ level, respectively.

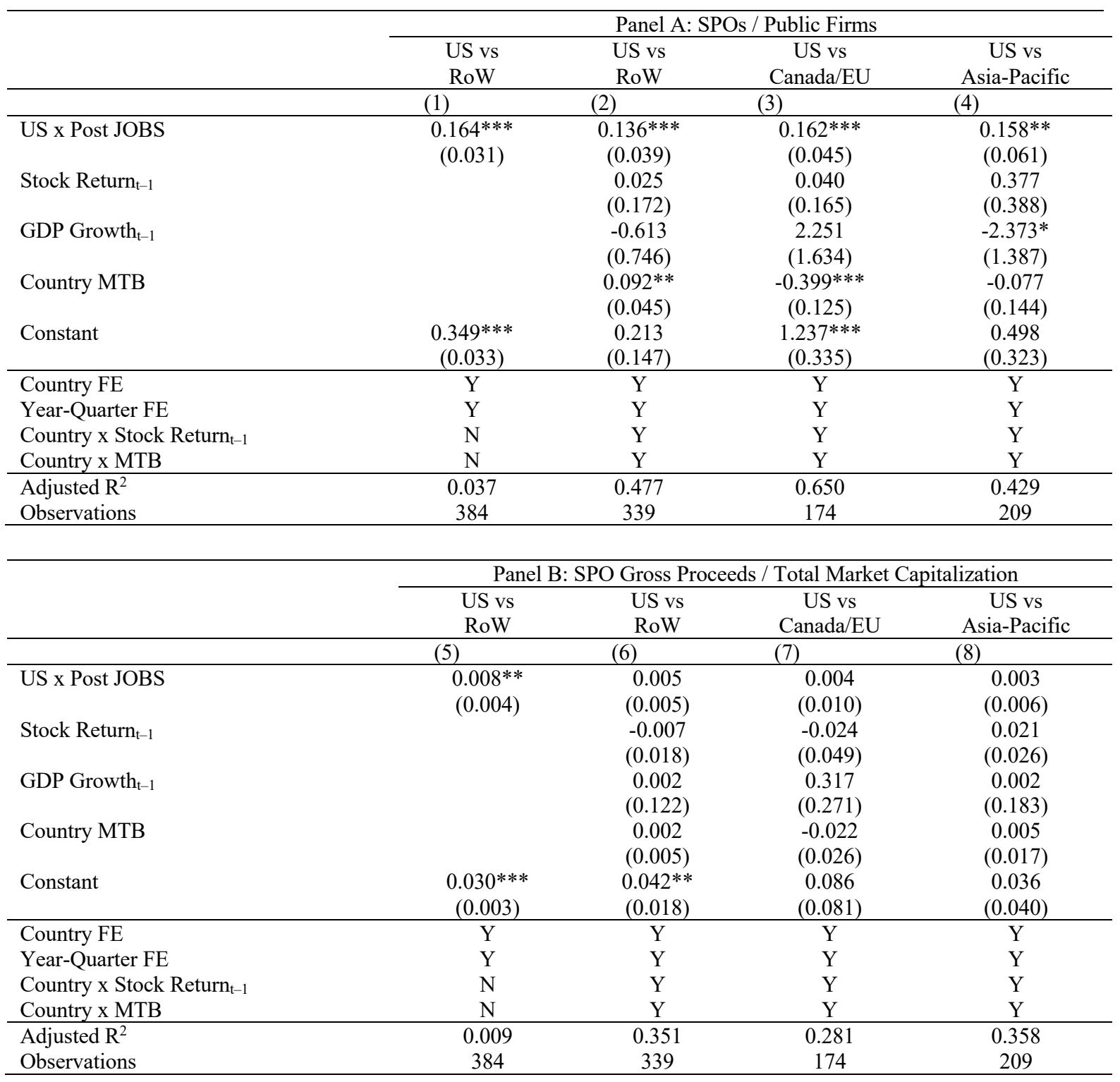


Table B3. Propensity score matching: covariate balances for SPO underpricing regressions: US versus developed countries

Table reports tests of covariate balance between US issuers (the treated group) and non-US issuers (the control group) of secondary public equity offers (SPOs). See the introduction to Appendix B for a description of the sample construction. To minimize bias, we restrict the sample to maintain similar calendar length before (January 1, 2008 to April 4, 2012) and after (April 6, 2012 and December 31, 2017) the JOBS Act. Each US SPO is matched to a control group of three nearest non-US SPOs using propensity scores based on observable issuer characteristics. The sample of non-US SPOs covers nine developed economies that have large and highly liquid public equity markets: Canada, United Kingdom, France, Germany, Italy, Australia, Japan, Hong Kong, and Singapore. For each set of matches, we impose an additional restriction that matching is done within the same offer year and period (i.e., matched US and non-US IPOs both occur pre-JOBS, or both occur postJOBS), and among issuers within the same two-digit SIC industry. $t$-stat indicates the difference in means between the variables of interest across the treated and control samples, while the $p$-value indicates statistical significance of the difference in means between the two matched samples.

\begin{tabular}{|c|c|c|c|c|}
\hline Variable & Mean (Treated) & Mean (Control) & t-stat & p-value \\
\hline Total Revenue & 278.97 & 284.08 & -0.48 & 0.629 \\
\hline Total Assets & 590.69 & 571.01 & 0.74 & 0.461 \\
\hline Long-term Debt & 213.06 & 196.57 & 1.36 & 0.173 \\
\hline Capital Expenditures & 1991.1 & 2128.7 & 0.32 & 0.746 \\
\hline Inventories & 1447 & 1634.3 & 0.49 & 0.622 \\
\hline
\end{tabular}


Table B4. Effect of the JOBS Act on SPO underpricing: US versus developed countries

Table presents OLS estimates of the effect of the JOBS Act on SPO underpricing (Indirect Equity Costs). The dependent variable, SPO underpricing, is estimated as minus one times the difference between previous day's closing price and the SPO offer price, divided by the previous day's closing price. See the introduction to Appendix B for a description of the sample construction. To minimize bias, we restrict the sample to maintain similar calendar length before (January 1, 2008 to April 4, 2012) and after (April 6, 2012 and December 31, 2017) the JOBS Act. The sample is obtained through a propensity score matching of US and NonUS SPOs based on observable pre-offer issuer characteristics as shown in Table B3. Post JOBS is a dummy variable equal to one if the SPO was issued in the period following the Act, and zero if the offer was issued in the prior period. US Issuer is a dummy term equal to one if issuer is domiciled in the US. EGC is a dummy term equal to one if the issuer went public as an "Emerging Growth Company" under the provisions of Title I of the JOBS Act. GDP growth is the quarter on quarter (QoQ) growth rate in real gross domestic product (GDP) of a country. Market cap (\% GDP) is the market capitalization of all publicly listed firms in a sample country expressed as percentage of the gross domestic product at the end of the most recent calendar year. Stock return (\%) is the monthly compounded stock market return for a sample country during the most recent twelve months. All specifications include country, industry and time (year-quarter) fixed effects. Robust standard errors are reported in parentheses. $*^{* *}, * *$, and $*$ denote significance at the $1 \%, 5 \%$, and $10 \%$ level, respectively.

\begin{tabular}{|c|c|c|c|c|}
\hline & $(1)$ & $(2)$ & (3) & $(4)$ \\
\hline Post JOBS x US Issuer & $\begin{array}{l}0.091 * * * \\
(0.010)\end{array}$ & $\begin{array}{l}0.076^{* * *} \\
(0.010)\end{array}$ & $\begin{array}{l}0.075^{* * *} \\
(0.010)\end{array}$ & $\begin{array}{c}0.059 * * * \\
(0.011)\end{array}$ \\
\hline Post JOBS x US Issuer x EGC & & & $\begin{array}{c}0.092 * * * \\
(0.031)\end{array}$ & $\begin{array}{c}0.086^{* * *} \\
(0.026)\end{array}$ \\
\hline EGC & & & $\begin{array}{l}-0.038 \\
(0.028)\end{array}$ & $\begin{array}{l}-0.031 \\
(0.022)\end{array}$ \\
\hline Log (Total assets) & & $\begin{array}{c}-0.008^{* *} \\
(0.004)\end{array}$ & & $\begin{array}{r}-0.007 * * \\
(0.004)\end{array}$ \\
\hline Debt to assets & & $\begin{array}{c}0.013 \\
(0.014)\end{array}$ & & $\begin{array}{c}0.015 \\
(0.014)\end{array}$ \\
\hline Profitability (EBITDA) & & $\begin{array}{l}-0.014 \\
(0.016)\end{array}$ & & $\begin{array}{l}-0.015 \\
(0.017)\end{array}$ \\
\hline Log (Offer size) & & $\begin{array}{l}-0.005 \\
(0.003)\end{array}$ & & $\begin{array}{l}-0.006^{*} \\
(0.003)\end{array}$ \\
\hline GDP growth t-1 & & $\begin{array}{c}0.807 * * \\
(0.372)\end{array}$ & & $\begin{array}{c}0.814 * * \\
(0.372)\end{array}$ \\
\hline Market cap (\% GDP) & & $\begin{array}{l}0.005 * * * \\
(0.001)\end{array}$ & & $\begin{array}{c}0.005 * * * \\
(0.001)\end{array}$ \\
\hline Stock return ${ }_{t-1}$ & & $\begin{array}{c}0.198 * * * \\
(0.044)\end{array}$ & & $\begin{array}{c}0.201 * * * \\
(0.044)\end{array}$ \\
\hline Constant & $\begin{array}{c}0.019 \\
(0.092)\end{array}$ & $\begin{array}{c}0.042 \\
(0.081)\end{array}$ & $\begin{array}{c}0.024 \\
(0.097)\end{array}$ & $\begin{array}{c}0.047 \\
(0.086)\end{array}$ \\
\hline Country/Industry/Year FE & $\mathrm{Y}$ & $\mathrm{Y}$ & $\mathrm{Y}$ & $\mathrm{Y}$ \\
\hline $\begin{array}{l}\text { Observations } \\
\text { Adjusted } \mathrm{R}^{2}\end{array}$ & $\begin{array}{l}3735 \\
0.449\end{array}$ & $\begin{array}{l}3595 \\
0.456\end{array}$ & $\begin{array}{l}3735 \\
0.452\end{array}$ & $\begin{array}{l}3595 \\
0.458\end{array}$ \\
\hline
\end{tabular}




\title{
C. Supplementary information on the JOBS Act
}

\author{
Table C1. Detailed timeline of the JOBS Act's passage
}

Table presents the timeline of events associated with the enactment of the JOBS Act by the US government. Details are obtained from Morrison and Foerster LLP (2016), the US Securities and Exchange Commission (SEC), and http://www.govtrack.us.

\begin{tabular}{|c|c|c|}
\hline Event & Dates & Description \\
\hline & Mar 14, 2011 & $\begin{array}{l}\text { Bill H.R.1070 titled "Small Company Capital Formation Act of } 2011 \text { " introduced } \\
\text { by Representative David Schweikert in the US House of Representatives, seeking } \\
\text { to amend the Securities Act by increasing the capital limit on public equity offerings } \\
\text { by small companies from } \$ 5 \text { million to } \$ 50 \text { million. Additional bills introduced } \\
\text { around the same time seeking to increase the threshold for mandatory registration } \\
\text { as a public company from } 500 \text { to } 2,000 \text { shareholders, and permit the general } \\
\text { solicitation and advertising private placements that are exempt from registration as } \\
\text { securities under Regulation D. }\end{array}$ \\
\hline
\end{tabular}

Nov 2, 2011 Bill H.R.1070 passed by the House and referred to the US Senate.

Dec 1, 2011 Bill H.R.1070 introduced as bill H.R. 3606 in the Senate under the title "Reopening American Capital Markets to Emerging Growth Companies Act of 2011" by Senator Charles Schumer.

Jan 31, 2012 US President Barack Obama releases the "Startup America Legislative Agenda" to the US Congress, expressing strong support for adopting the IPO on-ramp provisions recommended by the SEC and a host of other policies (crowdfunding, Regulation A etc.) aimed at boosting capital formation by smaller companies.

Mar 22, 2012 Bill H.R.3606 passed into law, and is henceforth known as the "Jumpstart Our Business Startups" (JOBS) Act.

The JOBS Act is signed into law by President Obama; Title I of the Act with its "IPO on-ramp" provisions is effective immediately.

Title I reduces the mandatory disclosure and registration requirements of IPOs for firms with annual gross revenues below $\$ 1$ billion by designating them as emerging growth companies (EGC). Firms that qualify as an EGC and maintain this status can take advantage of the following provisions:

- Seek confidential review of draft registration statements by the SEC (confidential registration statements must be made publicly available at least 15 days before the commencement of the roadshow).

- Can "test the waters" by engaging in oral or written communication with accredited investors and qualified institutional buyers (QIB) at any time before or after filing the initial registration statements.

- Are required to include only two years of audited financial statements, instead of three, as part of the initial registration statements.

- Are not subject to say-on-pay rules required under the Dodd-Frank Act.

- Must disclose the compensation of three instead of five executive offers, and only for the two previous fiscal years.

- Are exempt from auditor attestation as required under the Sarbanes-Oxley Act section 404(b). 
- Can be covered by research analysts during the pre-offer period, including by those affiliated with the participating underwriters and broker-dealers.

EGC firms can qualify for Title I exemptions when making secondary public equity offers for up to five years after the IPO as long as:

- Annual gross revenue is below \$1 billion (\$1.07 billion since April 1, 2017 due to inflation adjustments by the SEC).

- No more than $\$ 1$ billion issued as non-convertible debt in the three previous years.

- Is not a "large accelerated filer" with a public equity float of $\$ 700$ million or more as defined by the Exchange Act Rule 12b-2.

Title V of the JOBS Act, which raises the limit on the number of shareholders in a company from 500 to 2,000 before it is required to register as a public company with the SEC, is also effective immediately.

Jul 13, 2013 SEC adopts final amendments to Rule 506 and Rule 144a, as directed under Title II of the JOBS Act, to eliminate the general ban on solicitation and advertising of private placements issued under Regulation D. The SEC introduces a new Rule 506(c) under which firms can raise private capital by soliciting accredited investors.

Sep 23, 2013 Title II of the JOBS Act becomes effective.

Jun 19, 2015 Title IV of the JOBS Act is effective. Dubbed the "mini-IPO" rule, Title IV amends Regulation A and allows firms to raise up to $\$ 50$ million from accredited and nonaccredited investors, seek confidential review of registration statements, and testingthe-waters to gauge investor interest before filing the offer with the SEC.

May 16, 2016 Title III of the JOBS Act becomes effective, permitting investments from unaccredited investors via online crowdfunding portals registered with the SEC. 


\section{Figure C1. Example of S-1 filing by an EGC for initial public offering (IPO)}

Excerpts below are from the preliminary S-1 filing by Receptos, Inc. (central index key: 0001463729) dated April 4, 2013 for an initial public offering (IPO), and are retrieved from the SEC's EDGAR database.
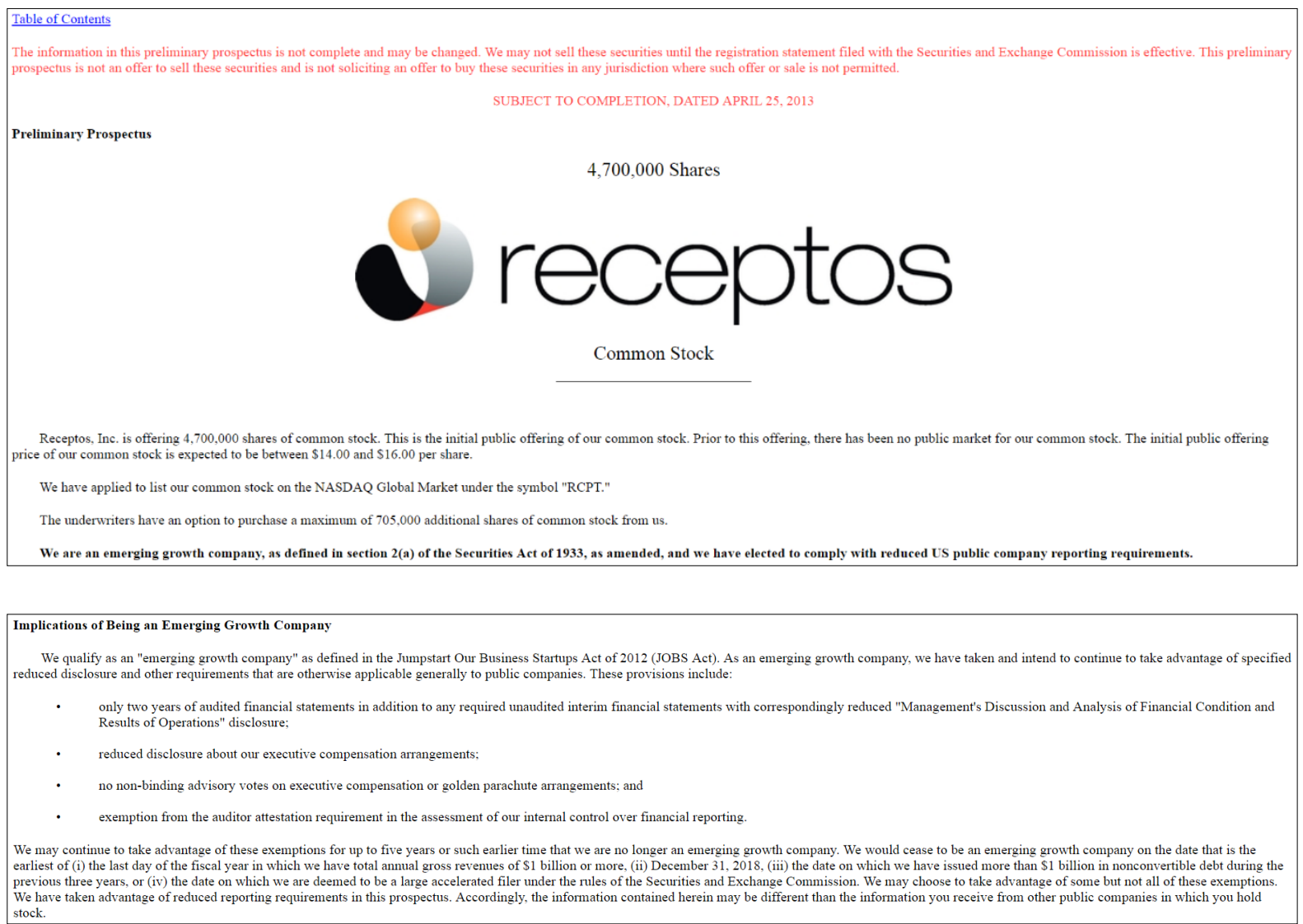

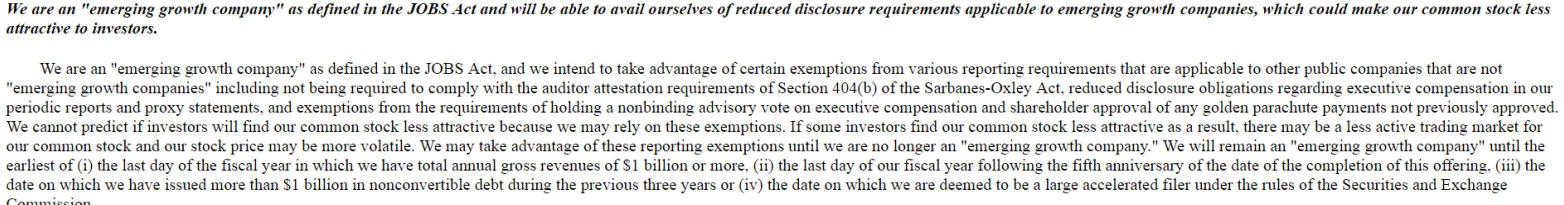

We are an "emerging growth company" as defined in the JOBS Act, and we intend to take advantage of certain exemptions from various reporting requirements that are applicable to other public companies that are not "umerging growth companies" including not being required to comply with the auditor attestation requirements of Section 404(b) of the Sarbanes-Oxley Act, reduced disclosure obligations regarding executive compensation in our We cannot predict if investors will find our common stock less attractive because we may rely on these exemptions. If some investors find our common stock less attractive as a result, there may be a less active trading market for our common slock and our stock price may be more volatile. We may take advantage of these reporting exemptions until we are no longer an "emerging growth company. "We will remain an "emerging growth company" until the earliest of (i) the last day of the fiscal year $m$ which we have total annual gross revenues of $\$ 1$ billon or more, (1i) the last day of our fiscal year following the fifth anniversary of the date of the completion of this offering, (iii) the date on which we have issued more than $\$ 1$ billion in nonconvertible debt during the previous three years or (iv) the date on which we are deemed to be a large accelerated filer under the rules of the Securities and Exchange (in) Emerging Growth Company. Status. From the time of first filing of the Registration Statement with the Commission (or, if earlier, the first date on which the Company engaged directly or through
any person authorized to act on its behalf in any communication in reliance on Section 5 (d) of the Act) through the date hereof, the Company has been and is an Emerging Growth Company.
(oo) Use of Testing-the-Waters Writings. The Company (a) has not alone engaged in communications with potential investors in reliance on Section 5 (d) of the Act other than Testing-the-Waters
Communications with entities that are qualified institutional buyers within the meaning of Rule 1444 under the Act or institutions sthat are accredited investors within the meaning of Rule 501 under the Act and (b) has not
authorized anyone other than the Underwriters to engage in such communications. The Company reconfirms that the Underwriters have been authorized to act on its behalf in communicating with potential investors in reliance on Section 5(d) of the Act. The Company has not distributed any Testing-the-Waters Writing 
Figure C2. Example of S-1 filing by an EGC for seasoned public offering (SPO)

Excerpts below are from the preliminary S-1 filing by Receptos, Inc. (central index key: 0001463729) dated December 24, 2013 for a seasoned public offering (IPO), and are retrieved from the SEC's EDGAR database.
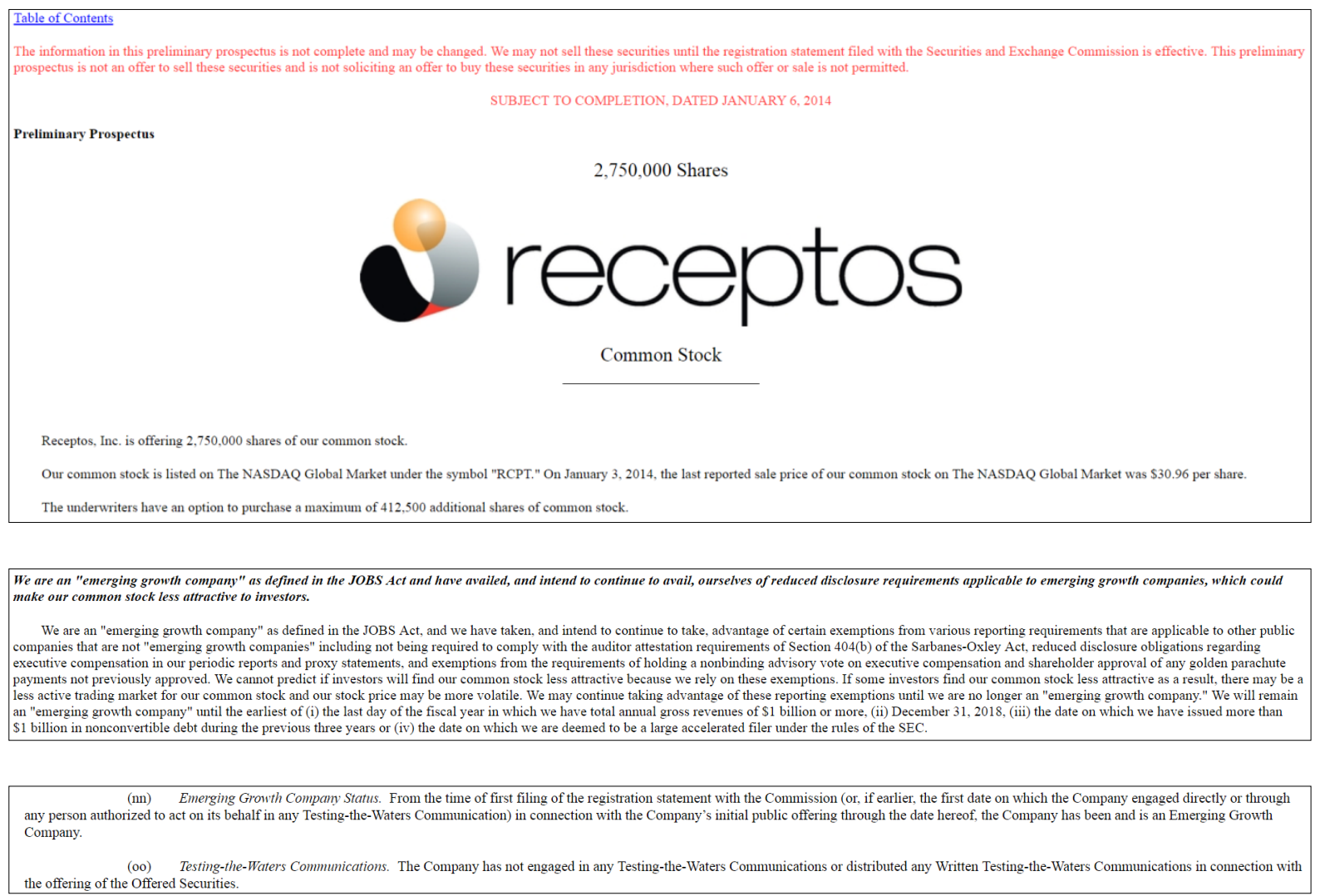


\section{Implications of EGC status loss on reporting costs}

One of the immediate consequences of losing EGC exemptions (due to LAF regulation) is the rise in disclosure obligations and associated reporting costs. In this section, we attempt to quantify the impact of EGC status loss on reporting costs by comparing the annual audit fees for the sample firms just below and above the $\$ 700$ million LAF cutoff.

Figure D1 provides a visual illustration of the fuzzy RD design based on equation (2.2). Among firms in the sample, only those that went public as an EGC are likely to be affected by the LAF rule. This allows us to compare the treatment effect $\beta_{1}$ for EGC and NonEGC firms that went public before the JOBS Act. Each plot in Figure D1 relates a firm's annual audit fees to its float in the most recent second fiscal quarter. Local linear regressions are fit on either side of the cutoff. The left-hand plot shows a sharp discontinuous rise in audit fees among ExEGC firms compared to EGCs below the cutoff that remain exempt. The right-hand plot shows no such discontinuity among NonEGC firms. ${ }^{44}$

Table D1 presents the OLS and IV estimates for audit fees around the LAF treatment cutoff. The choice of bandwidth $h$ follows from our main analysis. For robustness, we perform the regressions on three different bandwidths: $\$ 250, \$ 300$, and $\$ 350$ million, respectively. The coefficient of ExEGC in model (1) is positive and significant at the 1\% level, implying that a loss of EGC status leads to an immediate increase in reporting costs. Model (2) includes several controls specified in equation (2.2) which do not affect the statistical significance of the $E x E G C$ term. The coefficient of ExEGC in model (2) implies an annual increase of \$1.194 million in audit fees for the mean EGC firm after it loses its exemptions.

It is possible that EGCs will manipulate their float if they expect to lose exemptions due to the LAF regulation. If this is true, the OLS estimates will underestimate the true effect of EGC status loss because they cannot distinguish between EGCs that did, or did not, avoid compliance with LAF rules. We address these concerns using the IV methodology specified in equations (2.1) and (2.2). The ExEGC dummy representing loss of EGC status is instrumented with the PF700 dummy denoting whether the firm's float six months prior to the most recent second fiscal quarter exceeded $\$ 700$ million. The first stage regressions based on equation (2.1)

\footnotetext{
${ }^{44}$ Figure D2 shows further evidence of an increase in audit fees after an EGC loses its exemptions.
} 
are estimated using a linear probability model. The partial F-statistic has a highly significant value of at least 29.4 (model 4), implying strong instrument choice. The instrumented ExEGC has larger coefficients than the OLS estimates, but is weakly significant compared to the OLS estimates. The difference in statistical significance between the OLS and IV estimates shows that while EGCs affected by LAF regulation paid higher audit fees, many of them managed to remain below the cutoff by manipulating their float. Table A2 presents additional empirical evidence that EGCs attempt to evade LAF regulations by manipulating their float through share repurchases.

It is reasonable that EGCs with float closer to the $\$ 700$ million cutoff are able to evade the LAF rule more easily. Proximity to the cutoff means fewer resources are required to manipulate the float. Consequently, EGCs with a float way above the cutoff will find it more expensive to avoid becoming an LAF. To test this, we use larger bandwidths of \$300 and \$350 million and recompute the OLS and IV estimates. The results are shown in columns (5)-(12) of Table D1. Coefficients of ExEGC in the IV regressions are significant, both in statistical and economic terms. This shows that EGC firms that are farther away from the cutoff face a larger increase in audit fees upon status loss. While some of them may have attempted to lower their float, these efforts may have been insufficient in delaying compliance given these firms' larger distance to the cutoff. 


\section{Figure D1. EGC status loss and audit fees}

Figures plot annual audit fees over the running variable float, which is the total market value of common equity held by public investors on the last day of the preceding second fiscal quarter. Audit fees comprise audit and related fees paid by the company to its auditors for the relevant fiscal year. The sample comprises firms that went public as an "Emerging Growth Company" between April 6, 2012 and April 30, 2019. See Section 3.1 for a description of the sample construction. The left plot compares equity issuance among EGC and ExEGC firms. $E G C$ refers to firms that have float below $\$ 700$ million and thus remain exempt from mandatory disclosure under Title I of the JOBS Act. ExEGC refers to firms that have a float above $\$ 700$ million, and are therefore subject to mandatory disclosure under the "Large Accelerated Filer" (LAF) regulation. The plot on the right shows equity issuance among a placebo sample of NonEGC firms that went public before the JOBS Act (January 1, 2000-April 4, 2012) and thus did not quality for EGC treatment during their IPO. Local linear regressions are fit on either side of the LAF cutoff in each plot, as indicated by the blue lines. See Table A1 for a description of these variables.
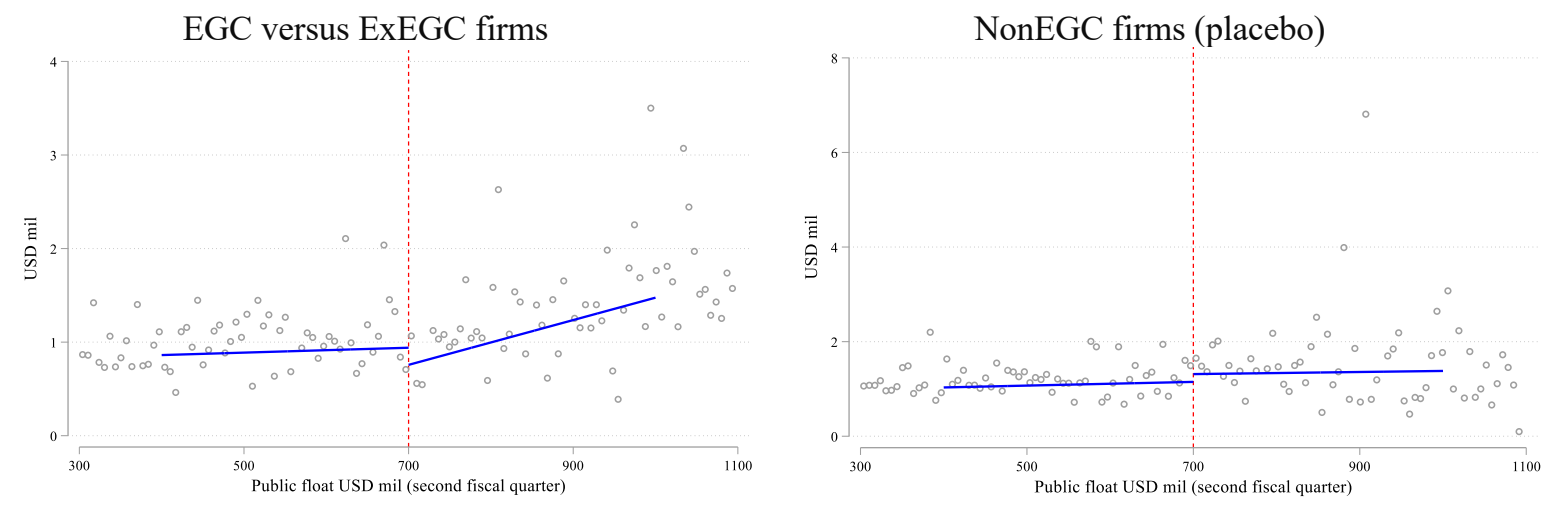

Figure D2. EGC status loss and audit fees: Density estimation

Figure shows the kernel density estimates of audit fees per year by EGC status. The sample comprises firms that went public as an "Emerging Growth Company" (EGC) between April 6, 2012 and April 30, 2019 and have float between $\$ 350$ and $\$ 1,050$ million. See Section 3.1 for a detailed description of the sample construction. Blue bars represent EGC firms that have float below $\$ 700$ million and thus remain exempt from mandatory disclosure under Title I of the JOBS Act. Red bars represent ExEGC firms that have a float above $\$ 700$ million and are therefore subject to mandatory disclosure under the "Large Accelerated Filer" (LAF) rules. We apply the Kolmogorov-Smirnov (KS) test and obtain a $D$-statistic of 0.3943 , which is statistically significant at the $1 \%$ level.

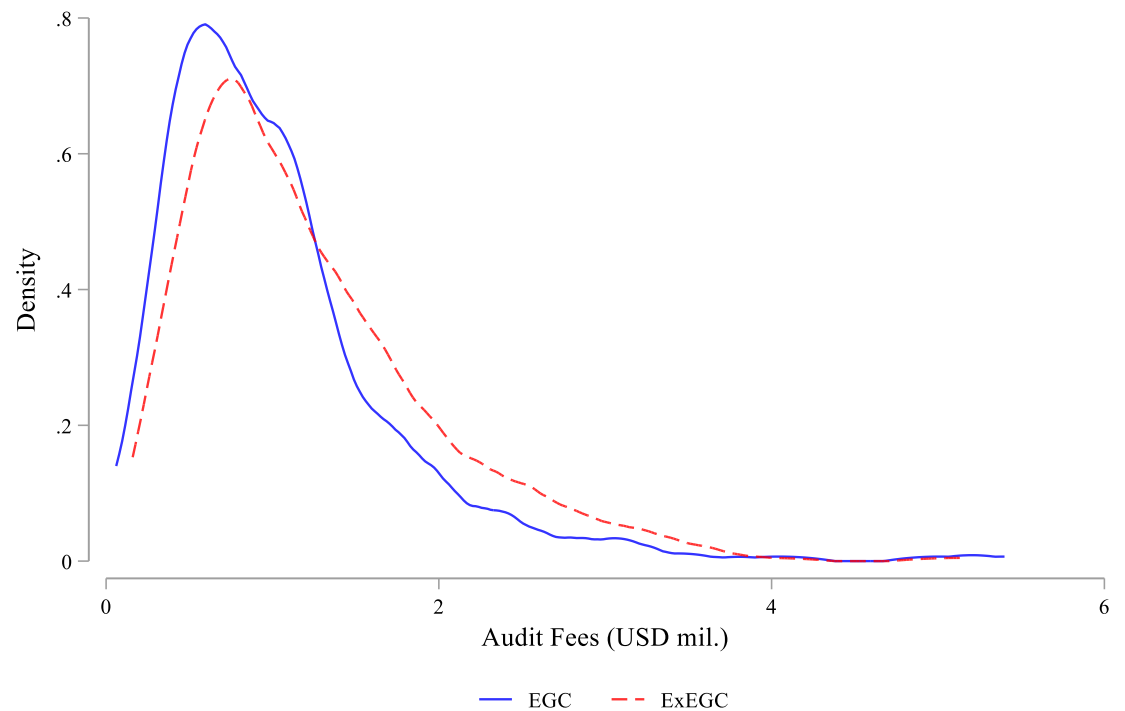


Table D1. Impact of EGC status loss on audit fees

Table presents regression discontinuity (RD) estimates where the dependent variable is the natural logarithm of audit fees. The OLS estimates are based on equation (1); the IV estimates are based on equations (2.1) and (2.2). The sample comprises firms that went public as an "Emerging Growth Company" (EGC) between April 6, 2012 and April 30, 2019. See Section 3.1 for a detailed description of the sample construction. ExEGC is a dummy equal to one for firms having a float above $\$ 700$ million at the end of second fiscal quarter that are subject to mandatory disclosure under the "Large Accelerated Filer" (LAF) regulation, and zero for firms whose float is below the threshold. We use three different bandwidths $h \in(\$ 250$ million, $\$ 300$ million, $\$ 350$ million) for the float around the LAF cutoff. For the IV regressions, ExEGC is the predicted treatment based on the first-stage model (2.1) using the variable $P F 700$ as an instrument. $P F 700$ is equal to one if the firm's float six months prior to the second fiscal quarter exceeds $\$ 700$ million, and zero otherwise. In all regressions, industry and year fixed effects are included. Standard errors are clustered by firm and are reported in parentheses. $* * *, * *$, and $*$ denote significance at the $1 \%, 5 \%$, and $10 \%$ level, respectively. See Table A1 for a detailed description of the variables.

\begin{tabular}{|c|c|c|c|c|c|c|c|c|c|c|c|c|}
\hline & \multicolumn{4}{|c|}{$h=\$ 250 \mathrm{~m}$} & \multicolumn{4}{|c|}{$h=\$ 300 \mathrm{~m}$} & \multicolumn{4}{|c|}{$h=\$ 350 \mathrm{~m}$} \\
\hline & \multicolumn{2}{|c|}{ OLS } & \multicolumn{2}{|c|}{ IV } & \multicolumn{2}{|c|}{ OLS } & \multicolumn{2}{|c|}{ IV } & \multicolumn{2}{|c|}{ OLS } & \multicolumn{2}{|c|}{ IV } \\
\hline & (1) & (2) & (3) & (4) & (5) & (6) & (7) & (8) & (9) & $(10)$ & $(11)$ & (12) \\
\hline ExEGC & $\begin{array}{c}0.173^{* * *} \\
(0.061)\end{array}$ & $\begin{array}{c}0.177^{* * *} \\
(0.064)\end{array}$ & $\begin{array}{c}0.268 \\
(0.164)\end{array}$ & $\begin{array}{l}0.292^{*} \\
(0.163)\end{array}$ & $\begin{array}{c}0.195 * * * \\
(0.052)\end{array}$ & $\begin{array}{c}0.176^{* * *} \\
(0.057)\end{array}$ & $\begin{array}{l}0.272^{* *} \\
(0.117)\end{array}$ & $\begin{array}{l}0.269^{* *} \\
(0.116)\end{array}$ & $\begin{array}{c}0.230^{* * * *} \\
(0.047)\end{array}$ & $\begin{array}{c}0.182^{* * *} \\
(0.054)\end{array}$ & $\begin{array}{c}0.340^{* * * *} \\
(0.097)\end{array}$ & $\begin{array}{c}0.268^{* * * *} \\
(0.104)\end{array}$ \\
\hline $\log (\text { Assets })_{t-1}$ & & $\begin{array}{c}0.210^{* * *} \\
(0.058)\end{array}$ & & $\begin{array}{c}0.205^{* * *} \\
(0.054)\end{array}$ & & $\begin{array}{c}0.226 * * * \\
(0.059)\end{array}$ & & $\begin{array}{c}0.217^{* * *} \\
(0.056)\end{array}$ & & $\begin{array}{c}0.235^{* * *} \\
(0.057)\end{array}$ & & $\begin{array}{c}0.224 * * * \\
(0.055)\end{array}$ \\
\hline $\log (\text { Employees })_{t-1}$ & & $\begin{array}{l}-0.004 \\
(0.011)\end{array}$ & & $\begin{array}{l}-0.005 \\
(0.010)\end{array}$ & & $\begin{array}{l}-0.003 \\
(0.009)\end{array}$ & & $\begin{array}{l}-0.004 \\
(0.009)\end{array}$ & & $\begin{array}{l}-0.004 \\
(0.009)\end{array}$ & & $\begin{array}{l}-0.004 \\
(0.008)\end{array}$ \\
\hline Debt to Assetst-1 & & $\begin{array}{c}0.188 \\
(0.118)\end{array}$ & & $\begin{array}{l}0.201^{*} \\
(0.114)\end{array}$ & & $\begin{array}{c}0.327^{* *} \\
(0.128)\end{array}$ & & $\begin{array}{c}0.346^{* * *} \\
(0.123)\end{array}$ & & $\begin{array}{l}0.221 * * \\
(0.107)\end{array}$ & & $\begin{array}{l}0.238^{* *} \\
(0.104)\end{array}$ \\
\hline Cash to Assets $t-1$ & & $\begin{array}{l}-0.090 \\
(0.149)\end{array}$ & & $\begin{array}{l}-0.096 \\
(0.135)\end{array}$ & & $\begin{array}{c}0.025 \\
(0.135)\end{array}$ & & $\begin{array}{c}0.026 \\
(0.126)\end{array}$ & & $\begin{array}{c}0.034 \\
(0.123)\end{array}$ & & $\begin{array}{l}0.040 \\
(0.116)\end{array}$ \\
\hline Capex to Assetst 1 & & $\begin{array}{c}0.083 \\
(0.680)\end{array}$ & & $\begin{array}{c}0.147 \\
(0.607)\end{array}$ & & $\begin{array}{c}0.309 \\
(0.595)\end{array}$ & & $\begin{array}{c}0.346 \\
(0.544)\end{array}$ & & $\begin{array}{c}0.384 \\
(0.519)\end{array}$ & & $\begin{array}{c}0.441 \\
(0.479)\end{array}$ \\
\hline$R \& D$ to Assetst -1 & & $\begin{array}{l}-0.545 \\
(0.441)\end{array}$ & & $\begin{array}{l}-0.552 \\
(0.410)\end{array}$ & & $\begin{array}{l}-0.127 \\
(0.303)\end{array}$ & & $\begin{array}{l}-0.128 \\
(0.285)\end{array}$ & & $\begin{array}{l}-0.280 \\
(0.330)\end{array}$ & & $\begin{array}{l}-0.287 \\
(0.310)\end{array}$ \\
\hline $\log (\text { Age })_{t-1}$ & & $\begin{array}{c}0.064 * * * \\
(0.022)\end{array}$ & & $\begin{array}{c}0.068 * * * \\
(0.021)\end{array}$ & & $\begin{array}{l}0.040^{*} \\
(0.021)\end{array}$ & & $\begin{array}{l}0.043^{* *} \\
(0.020)\end{array}$ & & $\begin{array}{c}0.029 \\
(0.021)\end{array}$ & & $\begin{array}{c}0.031 \\
(0.020)\end{array}$ \\
\hline Tobin's $\mathrm{Q}_{\mathrm{t}-1}$ & & $\begin{array}{l}-0.017 \\
(0.022)\end{array}$ & & $\begin{array}{l}-0.019 \\
(0.020)\end{array}$ & & $\begin{array}{l}-0.012 \\
(0.020)\end{array}$ & & $\begin{array}{l}-0.016 \\
(0.019)\end{array}$ & & $\begin{array}{l}-0.009 \\
(0.018)\end{array}$ & & $\begin{array}{l}-0.014 \\
(0.018)\end{array}$ \\
\hline $\log (\text { Board Size })_{\mathrm{t}-1}$ & & $\begin{array}{l}-0.009 \\
(0.078)\end{array}$ & & $\begin{array}{l}-0.025 \\
(0.074)\end{array}$ & & $\begin{array}{l}-0.065 \\
(0.072)\end{array}$ & & $\begin{array}{l}-0.072 \\
(0.069)\end{array}$ & & $\begin{array}{l}-0.016 \\
(0.061)\end{array}$ & & $\begin{array}{l}-0.022 \\
(0.059)\end{array}$ \\
\hline Board Independence $_{t-1}$ & & $\begin{array}{l}-0.189 \\
(0.216)\end{array}$ & & $\begin{array}{l}-0.172 \\
(0.193)\end{array}$ & & $\begin{array}{l}-0.077 \\
(0.205)\end{array}$ & & $\begin{array}{l}-0.055 \\
(0.190)\end{array}$ & & $\begin{array}{l}-0.117 \\
(0.174)\end{array}$ & & $\begin{array}{l}-0.101 \\
(0.163)\end{array}$ \\
\hline Stock Market Return & & $\begin{array}{l}2.352^{*} \\
(1.266)\end{array}$ & & $\begin{array}{l}2.143^{*} \\
(1.182)\end{array}$ & & $\begin{array}{c}0.641 \\
(1.108)\end{array}$ & & $\begin{array}{c}0.560 \\
(1.055)\end{array}$ & & $\begin{array}{c}0.626 \\
(0.973)\end{array}$ & & $\begin{array}{c}0.602 \\
(0.939)\end{array}$ \\
\hline Hot SPO Market & & $\begin{array}{c}0.047 \\
(0.124)\end{array}$ & & $\begin{array}{c}0.061 \\
(0.119)\end{array}$ & & $\begin{array}{c}0.059 \\
(0.107)\end{array}$ & & $\begin{array}{c}0.074 \\
(0.105)\end{array}$ & & $\begin{array}{c}0.057 \\
(0.093)\end{array}$ & & $\begin{array}{c}0.067 \\
(0.090)\end{array}$ \\
\hline Constant & $\begin{array}{c}-0.649 * * * \\
(0.208) \\
\end{array}$ & $\begin{array}{c}-1.785 * * * \\
(0.578) \\
\end{array}$ & $\begin{array}{c}0.073 \\
(0.150) \\
\end{array}$ & $\begin{array}{c}-1.207 * * * \\
(0.443) \\
\end{array}$ & $\begin{array}{c}-0.713 * * * \\
(0.169) \\
\end{array}$ & $\begin{array}{c}-1.840^{* * *} \\
(0.545) \\
\end{array}$ & $\begin{array}{c}-0.533 * * * \\
(0.159) \\
\end{array}$ & $\begin{array}{c}-2.160^{* * *} \\
(0.482)\end{array}$ & $\begin{array}{c}-0.758^{* * * *} \\
(0.141) \\
\end{array}$ & $\begin{array}{c}-1.927^{* * *} \\
(0.532) \\
\end{array}$ & $\begin{array}{c}-0.569 * * * \\
(0.149) \\
\end{array}$ & $\begin{array}{c}-2.155^{* * * *} \\
(0.463) \\
\end{array}$ \\
\hline Float Terms & $\mathrm{Y}$ & $\mathrm{Y}$ & $\mathrm{Y}$ & $\mathrm{Y}$ & $\mathrm{Y}$ & $\mathrm{Y}$ & $\mathrm{Y}$ & $\mathrm{Y}$ & $\mathrm{Y}$ & $\mathrm{Y}$ & $\mathrm{Y}$ & $\mathrm{Y}$ \\
\hline Industry/Year FE & $\mathrm{Y}$ & $\mathrm{Y}$ & $\mathrm{Y}$ & $\mathrm{Y}$ & $\mathrm{Y}$ & $\mathrm{Y}$ & $\mathrm{Y}$ & $\mathrm{Y}$ & $\mathrm{Y}$ & $\mathrm{Y}$ & $\mathrm{Y}$ & $\mathrm{Y}$ \\
\hline $\begin{array}{l}\text { Observations } \\
\text { Adiusted } \mathrm{R}^{2}\end{array}$ & $\begin{array}{c}323 \\
0228\end{array}$ & $\begin{array}{c}276 \\
0.431\end{array}$ & $\begin{array}{c}323 \\
0222\end{array}$ & $\begin{array}{c}276 \\
0.422\end{array}$ & $\begin{array}{c}431 \\
0253\end{array}$ & $\begin{array}{c}366 \\
0.413\end{array}$ & $\begin{array}{c}431 \\
0249\end{array}$ & $\begin{array}{c}366 \\
0.407\end{array}$ & $\begin{array}{c}521 \\
0296\end{array}$ & $\begin{array}{c}438 \\
0.439\end{array}$ & $\begin{array}{c}521 \\
0289\end{array}$ & $\begin{array}{c}438 \\
0.434\end{array}$ \\
\hline $\begin{array}{l}\text { First-stage } \mathrm{R}^{2} \\
\text { First Stage F-stat }\end{array}$ & & & $\begin{array}{c}0.175 \\
35.663\end{array}$ & $\begin{array}{c}0.185 \\
29.395\end{array}$ & & & $\begin{array}{c}0.232 \\
87.604\end{array}$ & $\begin{array}{c}0.245 \\
66.447\end{array}$ & & & $\begin{array}{c}0.268 \\
122.496\end{array}$ & $\begin{array}{c}0.491 \\
83.794\end{array}$ \\
\hline
\end{tabular}




\section{E. Implications of EGC status loss on earnings management}

In this section, we investigate whether compliance with LAF regulation had a material effect on the quality of earnings reported by EGC firms. In general, the fact that firms' performance is incorporated in the stock price means that they have an incentive to report positive earnings, and exceed the market's expectations from prior periods. Figure E1 presents regression discontinuity (RD) plots of the annual change in earnings per share (EPS) for the firms in our sample. The left-hand plot displays the year-on-year (YoY) change in EPS among EGC and ExEGC firms, and shows a strong discontinuity at the $\$ 700$ million LAF cutoff. The local linear fit to the left of the cutoff is upward sloping, suggesting that disclosure exemptions give EGCs greater discretion over reported earnings. Such discretion over earnings is not evident among ExEGC firms to the right of the LAF cutoff. The right-hand plot exhibits no such discontinuity in EPS among NonEGC firms that went public before Title I. Figure E2 presents additional evidence that EGC firms report lower earnings upon losing their disclosure exemptions due to the LAF regulation.

Our primary interest is in accruals, which is the noncash portion of earnings. Accruals are difficult to track but easier to manipulate to present a heathier image of the firm. Investors are often unaware of this practice and may be adversely affected by the inaccuracy of accruals. Depending on the firm industry, accruals can be decomposed into regular and discretionary accruals. In particular, discretionary accruals are a proxy for earnings management as they are easily subject to successful managerial manipulation (Teoh, Welch and Wong, 1998).

Following Iliev (2010), we compute discretionary actuals using the Jones (1991) model. First, accruals ${ }^{45}$ reported by a firm in a year are regressed against changes in sales, and property, plant, and equipment (PPE) in each two-digit SIC industry in Compustat (excluding the firm itself). Coefficients from this step are used to compute non-discretionary accruals for the firm. Subtracting non-discretionary accruals from reported accruals yields discretionary accruals.

We consider both accruals and discretionary accruals in our analysis. We perform both OLS and IV regressions, but report only the latter to save space. ${ }^{46}$ The IV estimates are shown in

\footnotetext{
${ }^{45}$ Accruals $=$ Earnings before extraordinary items - Operating cash flow from continuing operations.

${ }^{46}$ The OLS results are available on request. We observe that the IV estimates are smaller in magnitude relative to the OLS estimates. Consistent with our other findings, this leads us to conclude that EGC firms have had some limited success in delaying LAF compliance by manipulating their float.
} 
Table E1. Model (1) includes cash flow from operations and net income change (each scaled by lagged assets), as well as a negative cash flow dummy to account for overall economic activity within the firm. A lagged book-to-market ratio denoting growth opportunities and lagged equity denoting firm size are also included as controls. We also include more observable controls in model (2). A big-four auditor dummy captures variation in practices of the top four and other smaller accounting firms. Log (Board size), Board Independence, and CEO Duality control for quality of corporate governance.

Models (1)-(2) suggest that a change in EGC status due to mandatory disclosure leads to at least a $4.7 \%$ drop in reported accruals, equivalent to $\$ 13$ million lower earnings for the mean EGC firm. The effect of LAF compliance on EGCs is similar for discretionary accruals, and is statistically significant. The coefficients of ExEGC in model (3)-(4) suggest a minimum of 5\% reduction in discretionary accruals, implying a $\$ 13.8$ million drop in earnings for the mean EGC. These lower earnings cannot be attributed only to an increase in audit fees since the effect of LAF compliance on the latter amounts to just \$1.19 million per year for the mean EGC firm (see Appendix D).

As a robustness check, we repeat the analysis for wider bandwidths. The results presented in columns (5)-(12) of Table E1 are consistent with our main findings. 


\section{Figure E1. EGC status loss and earnings per share}

Figures plot year-on-year change in earnings per share (excluding extraordinary items) over the running variable float, which is the total market value of common equity held by public investors on the last day of the preceding second fiscal quarter. The sample comprises firms that went public as an "Emerging Growth Company" between April 6, 2012 and April 30, 2019. See Section 3.1 for a description of the sample construction. The left plot compares earnings per share among EGC and ExEGC firms. $E G C$ refers to firms that have float below $\$ 700$ million and thus remain exempt from mandatory disclosure under Title I of the JOBS Act. ExEGC refers to firms that have a float above $\$ 700$ million, and are therefore subject to mandatory disclosure under the "Large Accelerated Filer" (LAF) regulation. The plot on the right displays earnings per share among a placebo sample of NonEGC firms that went public before the JOBS Act (January 1, 2000-April 4, 2012) and thus did not quality for EGC treatment during their IPO. Local linear regressions are fit on either side of the LAF cutoff in each plot, as indicated by the blue lines. See Table A1 for a description of these variables.
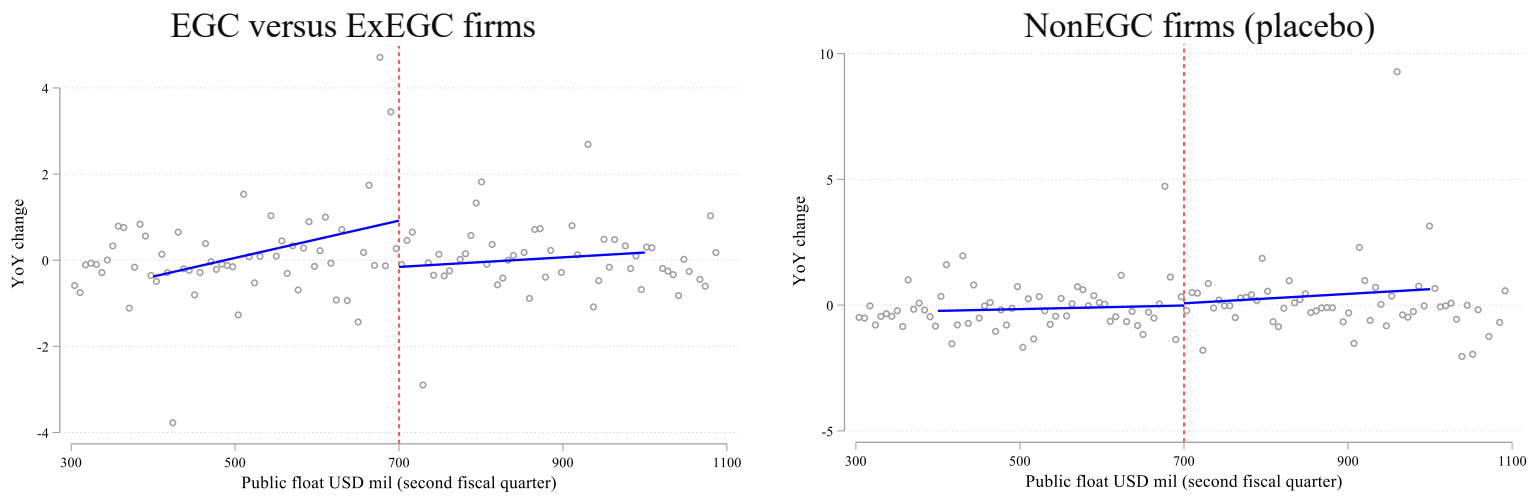

Figure E2. EGC status loss and earnings per share: Density estimation

Figure shows the kernel density estimates of reported earnings per share (excl. extraordinary items) per year by EGC status. The sample comprises firms that went public as an "Emerging Growth Company" (EGC) between April 6, 2012 and April 30, 2019 and have float between $\$ 350$ and $\$ 1,050$ million. See Section 3.1 for a detailed description of the sample construction. Blue bars represent EGC firms that have float below $\$ 700$ million and thus remain exempt from mandatory disclosure under Title I of the JOBS Act. Red bars represent ExEGC firms that have a float above $\$ 700$ million and are therefore subject to mandatory disclosure under the "Large Accelerated Filer" (LAF) rules. We apply the Kolmogorov-Smirnov (KS) test and obtain a $D$-statistic of $0.0902(p$-value $=0.151)$

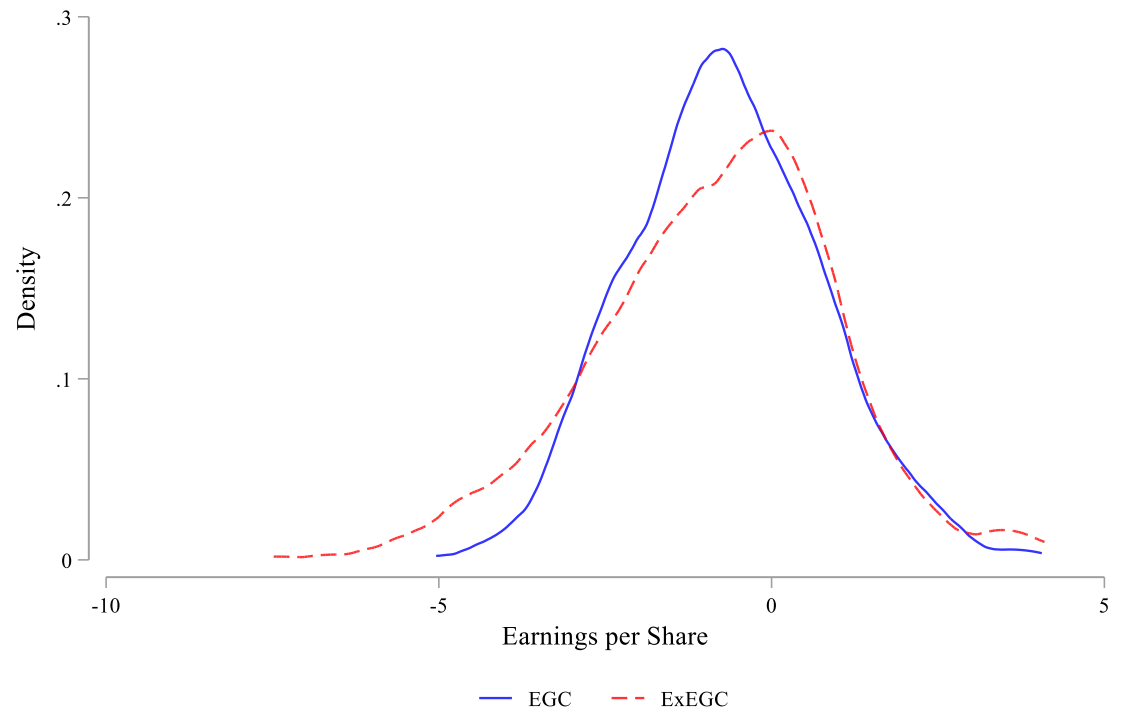


Table E1. Impact of EGC status loss on earnings reporting quality

Table presents IV regression estimates where the dependent variables are proxies for earnings management, namely Accruals and Discretionary Accruals. The IV estimates are based on equations (2.1) and (2.2). The sample comprises firms that went public as an "Emerging Growth Company" (EGC) between April 6, 2012 and April 30, 2019. See Section 3.1 for a detailed description of the sample construction. ExEGC is a dummy equal to one for firms having a float above $\$ 700$ million at the end of second fiscal quarter that are subject to mandatory disclosure under the "Large Accelerated Filer" (LAF) regulation, and zero for firms whose float is below the threshold. We use three different bandwidths $h \in(\$ 250$ million, $\$ 300$ million, $\$ 350$ million) for the float around the LAF cutoff. For the IV regressions, ExEGC is the predicted treatment based on the first-stage model (2.1) using the variable $P F 700$ as an instrument. $P F 700$ is equal to one if the firm's float six months prior to the second fiscal quarter exceeds $\$ 700$ million, and zero otherwise. In all regressions, industry and year fixed effects are included. Standard errors are clustered by firm and are reported in parentheses. $* * *, * *$, and $*$ denote significance at the $1 \%, 5 \%$, and $10 \%$ level, respectively. See Table A1 for a detailed description of the variables.

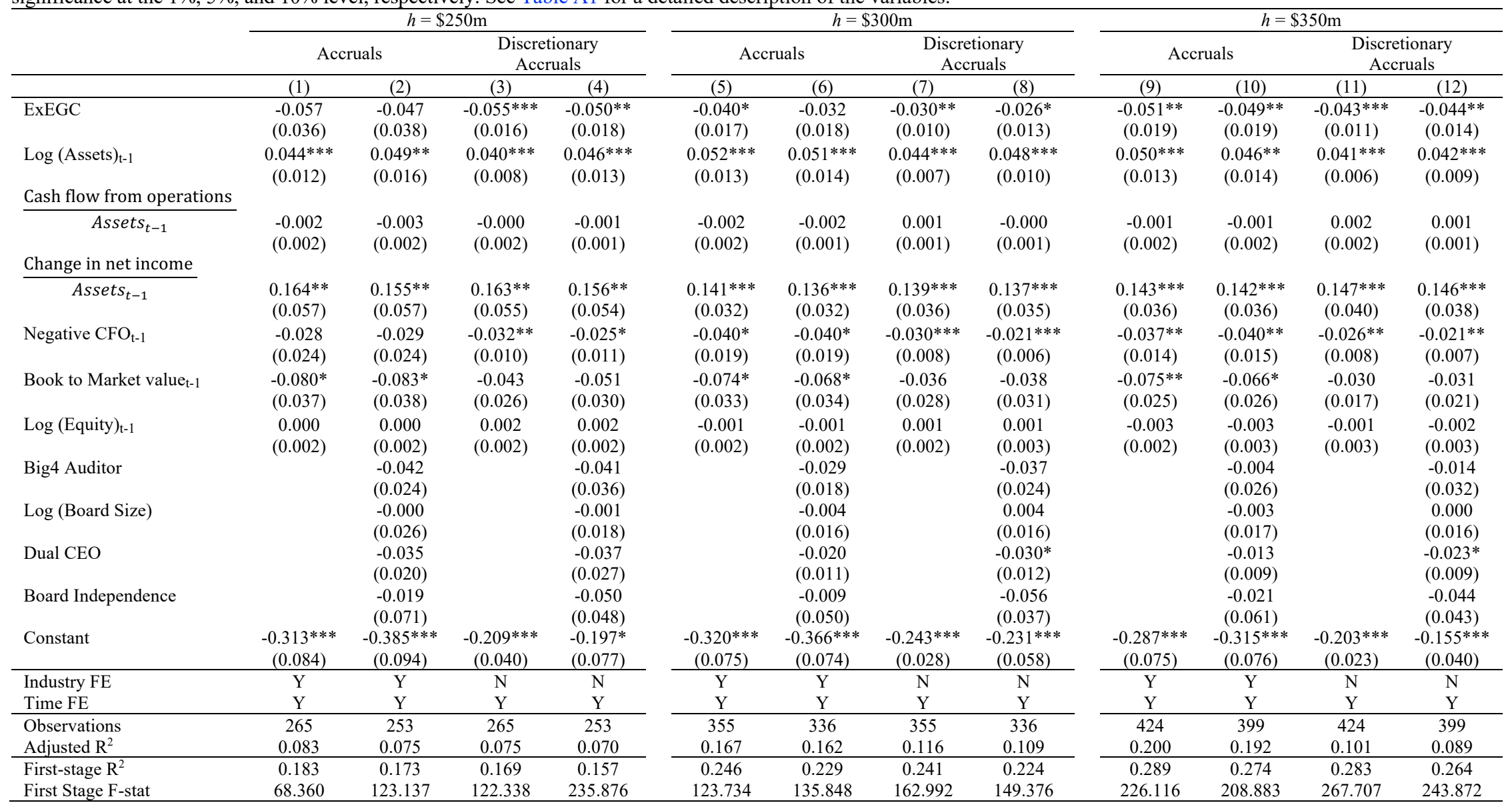

